$1 / 2 / 2,96 y+26$

\title{
Analysis of Potential Impacts of Flaming Gorge Dam Hydropower Operations on Archaeological Sites
}

Environmental Àssessment Division Argonne Nátional Laboratory

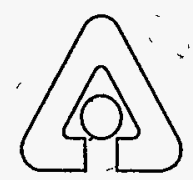

Operated by The University of Chicago, under Contract W-31-109-Eng-38, for the

United States Department of Energy 
Argonnè National'Laboratory:

Argonne National Laboratory, with facilities in the states of Illinois and Idaho, is owned by the United States Government, and operated by the University of Chicago under the provisions of a contract with the Department of Energy.

This technical memo is a product of Argonne's Environmental Asséssment Division (EAD). For information on the division's scientific and engineering activitiës, contact:

: Director,'Environmental Assessment Division

Argonne National Laboratory

Argonne, Illinóis 60439-48.15

Telephone (708) 252-3107.

Presented in this technical memo are preliminary results of ongoing work or work that is more limited in scope and depth than that described in formal reports issued by the EAD.

Publishing support services were provided by Argonne's Information and Publishing Divisision (for more information, see IPD's home page: http://www.jpd.anl.gov/)

\section{Disclaimer}

This report was prepared as an account of work sponsored by an agency of the United States Government. Neither the United States Government nor any agency thereof, nor any of their employees, makes any warranty, express or implied, or assumes any legal liability or responsibility for the accuracy, completeness, or usefulness of any information, apparatus, product, or process disclosed; or represents that its use would not infringe privately owned rights. Reference herein to any specific commercial product, processs, or service by trade name, trademark, manufacturer, or otherwise, does not necessarily constitute or imply its endorsement, recommendation, or favoring by the United States Government'or any agency thereof. The views and opinions of authors expressed herein do not necessarily state of reflect those of the United States Government or any agency thereof.

\section{Reproduced directly from the best available copy.}

Available to DOE and DOE contractors from the Office of Scientific and Technical Information, P.O. Box 62, Oak Ridge, TN 37831; prices available from (423) 576-8401.

Available to the public from the National Technical Information Service, U.S. Department of Commerce, 5285 Port Royal Road, Springfield; VA 22161. 


\section{Analysis of Potential Impacts of Flaming Gorge Dam Hydropower Operations on Archaeological Sites}

by K.L. Moeller, L.M. Malinowski, and J.F. Hoffecker

Environmental Assessment Division,

Argonne National Laboratory, 9700 South Cass Avenue, Argonne, Illinois 60439

December 1995

Work sponsored by United States Department of Energy,

Western Area Power Administration 
This report is printed on recycled paper. 


\section{FOREWORD}

This report is one of a series of technical memorandums prepared to support an environmental impact statement (EIS) on power marketing prepared by Argonne National Laboratory for the U.S. Department of Energy's Western Area Power Administration (Western). Western markets electricity produced at hydroelectric facilities operated by the Bureau of Reclamation. The facilities are known collectively as the Salt Lake City Area Integrated Projects (SLCA/IP) and include dams equipped for power generation on the Colorado, Green, Gunnison, and Rio Grande rivers and on Plateau Creek in the states of Arizona, Colorado, New Mexico, Utah, and Wyoming.

Western proposes to establish a level of commitment (sales) of long-term firm electrical capacity and energy from the SLCA/IP hydroelectric power plants; the impacts of this proposed action are evaluated in the EIS. Of the SLCA/IP facilities, only the Glen Canyon Dam, Flaming Gorge Dam, and Aspinall Unit (which includes Blue Mesa, Morrow Point, and Crystal dams) are influenced by Western's power scheduling and transmission decisions. For this reason, the impacts of hydropower operations at these three facilities were examined in the EIS.

The technical memorandums present detailed findings of studies conducted by Argonne National Laboratory specifically for the EIS. These studies are summarized in the EIS, and the results were used to assess environmental impacts related to alternative commitment levels. Technical memorandums were prepared on a number of socioeconomic and natural resource topics. Staff members of Argonne National Laboratory's Decision and Information Sciences Division and Environmental Assessment Division prepared these technical memorandums and the EIS as part of a joint effort managed by the Environmental Assessment Division. 


\section{CONTENTS}

FOREWORD $\ldots \ldots \ldots \ldots \ldots \ldots \ldots \ldots \ldots \ldots \ldots \ldots \ldots \ldots \ldots \ldots \ldots \ldots \ldots \ldots \ldots$ ii ACKNOWLEDGMENTS $\ldots \ldots \ldots \ldots \ldots \ldots \ldots \ldots \ldots \ldots \ldots \ldots \ldots \ldots \ldots \ldots$ viii

ABSTRACT $\ldots \ldots \ldots \ldots \ldots \ldots \ldots \ldots \ldots \ldots \ldots \ldots \ldots \ldots \ldots \ldots \ldots \ldots \ldots \ldots$

1 INTRODUCTION $\ldots \ldots \ldots \ldots \ldots \ldots \ldots \ldots \ldots \ldots \ldots \ldots \ldots \ldots \ldots \ldots \ldots \ldots$

2 ENVIRONMENTAL AND GEOLOGICAL SETTING $\ldots \ldots \ldots \ldots \ldots \ldots$

2.1 Geographic Setting $\ldots \ldots \ldots \ldots \ldots \ldots \ldots \ldots \ldots \ldots \ldots \ldots \ldots \ldots \ldots \ldots \ldots$

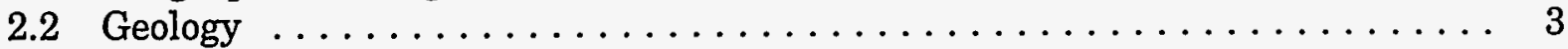

$2.3 \quad$ Flora and Fauna $\ldots \ldots \ldots \ldots \ldots \ldots \ldots \ldots \ldots \ldots \ldots \ldots \ldots \ldots \ldots \ldots \ldots \ldots \ldots$

3 REGIONAL PREHISTORY, HISTORY, AND ETHNOGRAPHY $\ldots \ldots \ldots \ldots \ldots$

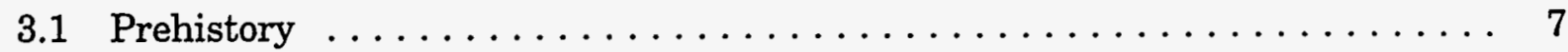

3.2 Euro-American History $\ldots \ldots \ldots \ldots \ldots \ldots \ldots \ldots \ldots \ldots \ldots \ldots \ldots \ldots \ldots \ldots$

4 RESEARCH DESIGN AND METHODOLOGY $\ldots \ldots \ldots \ldots \ldots \ldots \ldots \ldots$

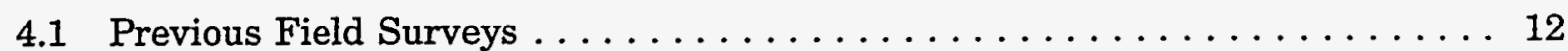

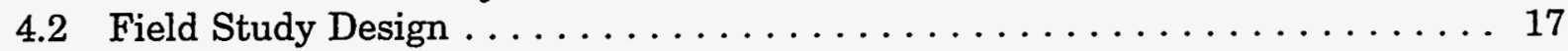

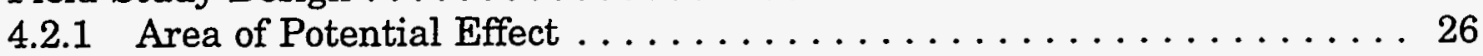

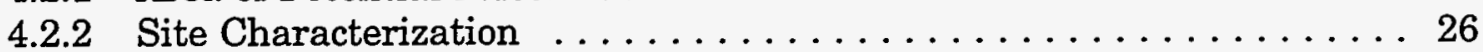

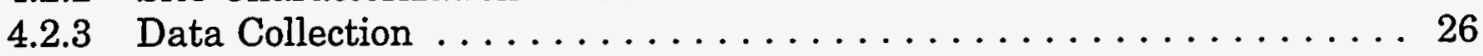

5 DISTRIBUTION OF ARCHAEOLOGICAL REMAINS AND GEOMORPHOLOGY $\ldots \ldots \ldots \ldots \ldots \ldots \ldots \ldots \ldots \ldots \ldots \ldots \ldots \ldots \ldots \ldots \ldots$

6 ANALYSIS OF IMPACTS TO ARCHAEOLOGICAL REMAINS $\ldots \ldots \ldots \ldots \ldots 35$

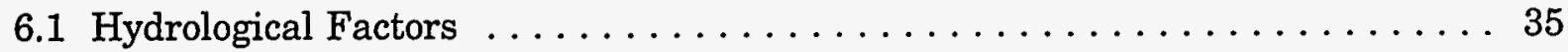

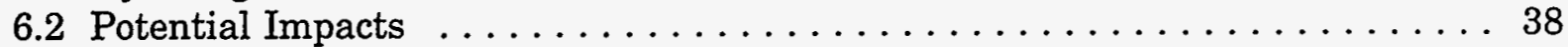

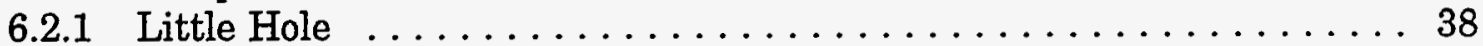

6.2.2 Upper Browns Park $\ldots \ldots \ldots \ldots \ldots \ldots \ldots \ldots \ldots \ldots \ldots \ldots$

6.2.3 Lower Browns Park $\ldots \ldots \ldots \ldots \ldots \ldots \ldots \ldots \ldots \ldots \ldots \ldots$

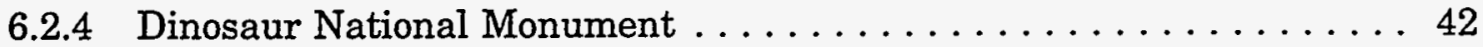

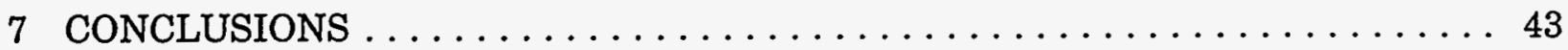

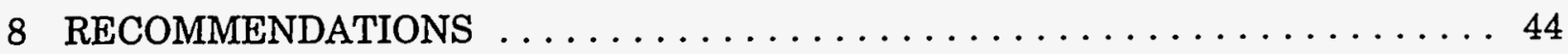

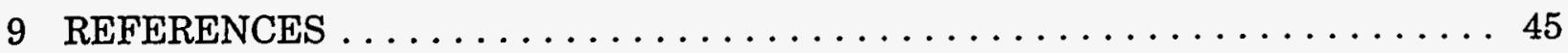




\section{CONTENTS (Cont.)}

APPENDIX A: Recorded and Previously Unrecorded Archaeological Sites from Flaming Gorge Dam to the Yampa River Confluence

APPENDIX B: Archaeological Site Impact Analysis Data Forms . . . . . . . . . 63

\section{FIGURES}

$1 \quad$ Field Study Area along the Green River $\ldots \ldots \ldots \ldots \ldots \ldots \ldots$

2 Previous Archaeological Surveys at Little Hole $\ldots \ldots \ldots \ldots \ldots \ldots$

3 Previous Archaeological Surveys of Upper Browns Park: Map $1 \ldots \ldots$. . . . . . 20

4 Previous Archaeological Surveys of Upper Browns Park: Map 2 . . . . . . 21

5 Previous Archaeological Surveys of Lower Browns Park: Map $1 \ldots \ldots$. . . . . 23

6 Previous Archaeological Surveys of Lower Browns Park: Map 2 . . . . . . . . 24

7 Previous Archaeological Surveys of Lower Browns Park: Map $3 \ldots \ldots$. . . . . 25

8 Schematic Cross Section of Archaeological Site Distribution and Geomorphic Features in the Green River Field Study Area . . . . . . . . . . 33

\section{TABLES}

1 Flora in the Study Area $\ldots \ldots \ldots \ldots \ldots \ldots \ldots \ldots \ldots \ldots \ldots \ldots$

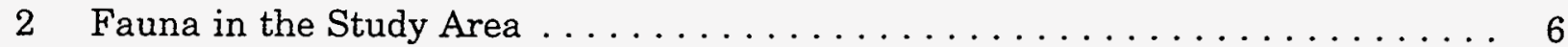

3 Previous Field Surveys in the Little Hole Area . . . . . . . . . . . . . . . . 14

4 Previous Field Surveys in the Upper Browns Park Area . . . . . . . . . . . 18

5 Previous Field Surveys in the Lower Browns Park Area . . . . . . . . . . . . 22

6 Sites Evaluated within the Potentially Affected Area . . . . . . . . . . . . 27

7 Archaeological Sites and Historic Structures Downstream of Flaming Gorge Dam that Could Be Affected by Hydropower Operational Scenarios . . . . . . . . 36 


\section{TABLES (Cont.)}

8 Summary of Sand Load in Browns Park $\ldots \ldots \ldots \ldots \ldots \ldots \ldots \ldots \ldots \ldots$

9 Summary of Impacts to Cultural Resources below Flaming Gorge Dam . . . . . 43

A.1 Recorded Archaeological Sites from Flaming Gorge Dam to the Yampa

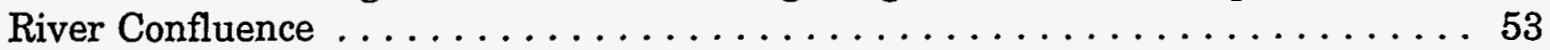

A.2 Previously Unrecorded Archaeological Sites from Flaming Gorge Dam

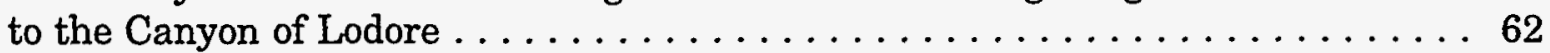




\section{ACKNOWLEDGMENTS}

Throughout the course of the field study and the preparation of this report, several agencies were of tremendous help. We would like to thank the following people. Byron Loosle from the Ashley National Forest Service joined us in our survey of Little Hole (June 16, 1992) and offered useful insights about the Little Hole area. He also provided significant help in preparation of the Class I overview. From the Bureau of Land Management in Vernal, Utah, Blaine Phillips provided assistance in Upper Browns Park, and Glade Hadden, Corinne Jacobson, and Mike Paolui joined us in our survey from John Jarvie Ranch through Swallow Canyon (June 17, 1992). Blaine Phillips also provided input into the Class I overview. We were on our own in Lower Browns Park (June 18, 1992), but we would like to thank the U.S. Fish and Wildlife Service for allowing us to survey within the Browns Park National Wildlife Refuge. Anne McKibbin from Metcalf Archaeological Consultants, Inc., helped us by providing information from the Questar North-South Pipeline Project. We would also like to thank James Truesdale, also from Metcalf Archaeological Consultants, Inc., for his input throughout the Class I overview and field study. From the State of Utah, Division of State History, Kevin Jones and James Dykman provided assistance in preparing for this field study and in the consultation process which followed the survey. Mary Sullivan and James Green from the Colorado Historical Society also provided helpful comments regarding the field study. 


\title{
ANALYSIS OF POTENTIAL IMPACTS OF FLAMING GORGE DAM HYDROPOWER OPERATIONS ON ARCHAEOLOGICAL SITES
}

by

\author{
K.L. Moeller, L.M. Malinowski, and J.F. Hoffecker
}

\begin{abstract}
An archaeological field study was conducted along the Green River in the areas of Little Hole and Browns Park in Utah and Colorado. The purpose of the study was to measure the potential for hydropower operations at Flaming Gorge Dam to directly or indirectly affect archaeological sites in the study area. Thirty-four known sites were relocated, and six new sites were recorded. Information was collected at each site regarding location, description, geomorphic setting, sedimentary context, vegetation, slope, distance from river, elevation above river level, and site condition. Matching the hydrologic projections of river level and sediment load with the geomorphic and sedimentary context at specific site locations indicated that eight sites were in areas with a high potential for erosion.
\end{abstract}

\section{INTRODUCTION}

An archaeological field study was conducted along the Green River in areas of Little Hole and Browns Park, Utah and Colorado, to address the effects on cultural resources of several potential hydropower operational scenarios at Flaming Gorge Dam, Utah. Cultural resources include archaeological and historic sites, structures, and features (e.g., rockshelters, campsites, buildings, trails) that are protected under various federal laws, such as the National Historic Preservation Act and the Archaeological Resources Protection Act. Cultural resources also include sacred and traditional use areas that are important to a community's practices and beliefs and that are necessary to maintain the cultural identity of the community. "Significant" cultural resources are those that meet eligibility criteria for the National Register of Historic Places and must be considered when federal undertakings are planned (Title 36, Code of Federal Regulations, Part 60 [36 CFR Part 60]). In addition, federal agencies are required to consider the effects of their planned actions on sites, areas, or other resources (e.g., sacred plants) that are of religious significance to Native Americans, as stated in the American Indian Religious Freedom Act. The repatriation of Native American remains and associated cultural objects on federal or tribal lands is provided for by the Native American Graves Protection and Repatriation Act.

The effects of hydropower operational scenarios at Glen Canyon Dam (Colorado River), Flaming Gorge Dam (Green River), and the Aspinall Unit (Gunnison River) were 
assessed in the Western Area Power Administration's Electric Power Marketing Final Environmental Impact Statement (EIS) (U.S. Department of Energy [DOE] 1996). An assessment of potential effects on cultural resources is required as part of the EIS process. In compliance with the National Historic Preservation Act and the National Environmental Policy Act, Moeller et al. (1993) completed a Class I overview that examined existing information concerning cultural resources in the Flaming Gorge and Aspinall study areas. A separate process had been undertaken earlier for Glen Canyon Dam.

The operational scenarios considered for Flaming Gorge Dam were year-round high fluctuating flows, seasonally adjusted high fluctuating flows, seasonally adjusted moderate fluctuating flows, and seasonally adjusted steady flows. The assessment of Flaming Gorge Dam focused primarily on the potential effects of hydropower operations downstream of the dam. At the Aspinall Unit, the primary focus was the three reservoirs rather than downstream effects.

The Class I overview included a review of background information on environmental setting, prehistory, and history; a brief description of the regional ethnography; a review of previous field surveys; and an inventory of known archaeological and historic sites, structures, and features in the two study areas: (1) for Flaming Gorge Dam, from the dam to Cub Creek on the Green River, and (2) for the Aspinall Unit, from Blue Mesa Reservoir to Crystal Dam on the Gunnison River. Specific sites, areas, and resources of significance to Native Americans were not included in the overview; however, they have been addressed in the EIS (DOE 1996). The primary focus of the Class I overview was the inventory; the background information was provided to serve as a framework and basis for evaluation and interpretation. The inventory strategy was developed through a detailed search of the general literature and of reports, files, and maps provided by the State Historic Preservation Offices in Colorado and Utah and by other federal agencies, such as the U.S. Forest Service, National Park Service, and Bureau of Land Management (BLM). The results of the overview indicated that about 7\% of the Green River and $80 \%$ of the Gunnison River study areas have been subject to $100 \%$ intensive surveys; about $68 \%$ of the Green River study area has also been subject to less intensive sampling surveys. At least 144 sites (107 prehistoric, 31 historic, and 6 combined prehistoric/historic) have been recorded for the Green River and 144 sites (140 prehistoric and 4 historic) for the Gunnison River (Moeller et al. 1993).

On the basis of the Class I Overview, a pilot field study was considered an effective approach to assess the alternative hydropower operational scenarios considered for Flaming Gorge Dam in the EIS. The field study was designed to evaluate the potential adverse effects related to hydropower operations on properties eligible for inclusion in the National Register. The identification of adverse effects to significant cultural resources would suggest the need for an intensive survey to determine effects to all properties eligible for the National Register. The objectives of the field study were to relocate previously recorded sites in noncanyon areas below Flaming Gorge Dam, record their position with respect to the river (along with other contextual information), evaluate their condition, and assess potential effects related to hydropower operations of the dam. The results of the Green River field study are presented in this document. 


\section{ENVIRONMENTAL AND GEOLOGICAL SETTING}

\subsection{GEOGRAPHIC SETTING}

The area examined in the Green River field study extends along the Green River from Flaming Gorge Dam to Canyon of Lodore in the Eastern Uinta Mountain range of northeastern Utah and northwestern Colorado. The study focused primarily on areas outside the bedrock canyons: Little Hole, Upper Browns Park (upstream of Swallow Canyon), and Lower Browns Park (downstream of Swallow Canyon) (Figure 1). The steep-walled canyons - which include Red Canyon (a 30-mile long canyon directly below Flaming Gorge Dam), Swallow Canyon, and Canyon of Lodore - are cut into uplifted Precambrian bedrock and contain few younger deposits. These areas possess a very low potential for archaeological remains. Below Canyon of Lodore, the Yampa River carries a higher volume of water and additional sediment into the river system; this cultural resources field study was confined to areas upstream of the Yampa confluence because it had not yet been determined if hydropower generation at Flaming Gorge Dam would have any impact below the Yampa.

\subsection{GEOLOGY}

The principal bedrock unit in the study area is the Precambrian Uinta Mountain Group, which is composed primarily of sandstone and quartzite. The bedrock canyons (Red Canyon, Swallow Canyon, and Canyon of Lodore) are incised through this formation, which also crops out in other portions of the study area. The only other major pre-Quaternary formation along the river corridor is the Miocene Browns Park Formation, which comprises volcanic tuff and tuffaceous sandstone interbedded with conglomerate, siltstone, sandstone, and clay (Hansen 1965, 1975).

Quaternary deposits in the study area include terraces, tributary alluvium, and aeolian sediment (Hansen 1965:131-137). These deposits are almost exclusively confined to Little Hole, Devils Hole, and Browns Park. Hansen (1965:131-132) identified five Pleistocene terraces or bench gravels composed of poorly sorted pebbles and gravels (chiefly derived from the Precambrian formations) interbedded with lenses of sand and silt. The three oldest levels of bench gravels exhibit deep weathering profiles and apparently antedate the Wisconsin Glaciation. The two youngest levels (mapped as $\mathrm{Qb}_{4}$ and $\mathrm{Qb}_{5}$ ) are less than $20 \mathrm{ft}$ above the modern floodplain. At least one Holocene terrace ( 6 to $9 \mathrm{ft}$ ) composed of sand is also present in Little Hole and Browns Park. According to Eddy et al. (1982:12), the modern soil profile on this terrace is no more than 150 years old. Extensive alluvial deposits (primarily sand and silt) occur along tributary streams; remains of modern bison (Bison bison) recovered from these deposits also indicate Holocene age (Hansen 1965:133). Aeolian sand, derived from the modern floodplain and older alluvial deposits, has accumulated in many areas, forming active or stabilized dunes. 


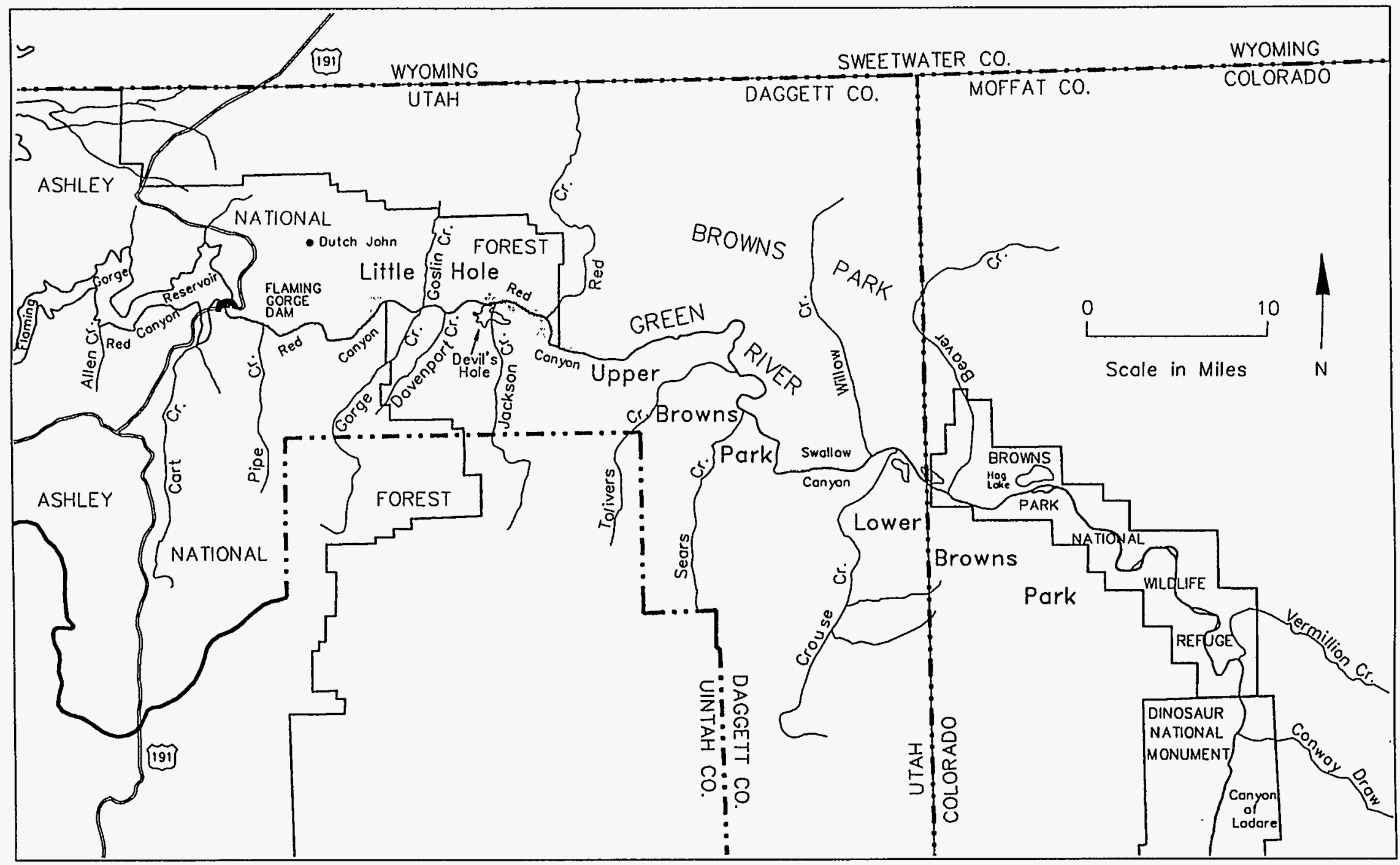

FIGURE 1 Field Study Area along the Green River 


\subsection{FLORA AND FAUNA}

, Vegetation within Red Canyon and areas surrounding Browns Park consists chiefly of pinyon pine, juniper, mountain mahogany, gambel oak, bitterbrush or antelope brush, cheatgrass, snakeweed, and sagebrush. The vegetation along the Green River in Little Hole and Browns Park is assigned to a cold desert community, which includes rabbitbrush, shadscale, cottonhorn horsebrush, mat saltbrush, and small sagebrush. Common species observed along the Green River in the study area include prickly pear cactus, Russian thistle, Indian ricegrass, and the riparian species greasewood, cottonwood, and nonnative tamarisk (Norman and Merrill 1981:6-7; Eddy et al. 1982:17; Billat 1990:7) (Table 1).

Fauna in the study area include mule deer, pronghorn antelope, elk, bighorn sheep, coyote, badger, beaver, striped skunk, and several varieties of rabbits, squirrels, prairie dogs, and chipmunks. Moose and black bear are present in the nearby Uinta Mountains. Bison were present during prehistoric and early historic times (Hansen 1965:133; Norman and Merrill 1981:7). Birds found in the study area include sage grouse, Gambel's quail, Chukar partridge, migratory waterfowl (ducks, geese, shorebirds), raven, songbirds, and raptors (primarily hawks, falcons, owls, and golden eagles) (Meyer and Riches 1979:2; Norman and Merrill 1981:7; Woodward-Clyde 1985:B-9; Billat 1990:7). Squawfish, humpback chub, and several species of trout are present in the Green River (Norman and Merrill 1981:7; Woodward-Clyde 1985:B-9) (Table 2).

TABLE 1 Flora in the Study Area

\begin{tabular}{ll}
\hline \multicolumn{1}{c}{ Common Name } & \multicolumn{1}{c}{ Scientific Name } \\
\hline Bitterbrush/Antelope brush & $\begin{array}{l}\text { Purshia tridentata } \\
\text { Cheatgrass }\end{array}$ \\
Cottonhorn horsebrush & Tetradymia spinosa \\
Cottonwood & Populus fremontii \\
Gambel oak & Quercus gambelii \\
Greasewood & Sarcobatus vermiculatus \\
Indian ricegrass & Oryzopsis hymanoides \\
Mat saltbrush & Atriplex corrugata \\
Mountain mahogany & Cercocarpus montanus \\
One-seed juniper & Juniperus monosperma \\
Pinyon pine & Pinus edulis \\
Prickly pear cactus & Opuntia polyacantha \\
Rabbitbrush & Chrysothamnus nauseosus \\
Russian thistle & Salsola kali \\
Sagebrush & Artemisia tridentata \\
Shadscale & Atriplex confertifolia \\
Small sagebrush & Artemisia nova \\
Snakeweed & Gutierrezia sarothrae \\
Tamarisk & Tamarix ramosissima \\
Utah juniper & Juniperus osteosperma \\
\hline
\end{tabular}


TABLE 2 Fauna in the Study Area

\begin{tabular}{llll}
\hline Common Name & \multicolumn{1}{c}{ Scientific Name } & Common Name & \multicolumn{1}{c}{ Scientific Name } \\
\hline Mammals & & Birds & \\
Badger & Taxidea taxis & Canada goose & Branta canadensis \\
Beaver & Castor canadensis & Chukar & Alectoris chukar \\
Bighorn sheep & Ovis canadensis & Falcons & Falco spp. \\
Bison $^{2}$ & Bison bison & Gambel's quail & Lophortyx gambelii \\
Black bear $_{\text {Chipmunks }}^{\text {Ursus americanus }}$ & Golden eagle & Aquila chrysaetos \\
Cottontail rabbits & Syluilagus spp. & Harrier & Circus cyaneus \\
Coyote & Canis latrans & Hawks & Buteo. spp. \\
Elk & Cervus canadensis & Raven & Corvus corax \\
Ground squirrels & Spermophilus spp. & Sage grouse & Centrocercus urophasianus \\
Moose & Alces americanus & Fish & \\
Mule deer & Odocoileus hemionus & Humpback chub & Gila cypha \\
Prairie dogs & Cynomys spp. & Squawfish & Ptychocheilus lucius \\
Pronghorn antelope & Antilocapra americana & & \\
Rabbits & Lepus spp. & & \\
Squirrels & Citellus spp. & & \\
Striped skunk & Mephitis mephitis & & \\
\hline
\end{tabular}

a Prehistoric/Historic. 


\section{REGIONAL PREHISTORY, HISTORY, AND ETHNOGRAPHY}

\subsection{PREHISTORY}

The prehistoric archaeology of the Uinta Basin of northeastern Utah and northwestern Colorado is included in the Eastern Great Basin culture area. However, geographically, the Uinta Basin lies in a transitional area between the Colorado Plateau and the northwestern Plains, with the hydrographic "Great Basin" just to the west (Jennings 1986:113).

The Eastern Great Basin contains a multitude of fertile microenvironments that supported prehistoric populations in an otherwise arid climate, resulting in many local cultural developments (Jennings 1986:113-114). The majority of information regarding the prehistoric archaeology of the area has been collected from excavations of rockshelters and cave sites. Specifically, excavations at Deluge Shelter, Swelter Shelter, Thorne Cave, and the open-air site of Hells Midden have provided invaluable data on Uinta Basin prehistory (Aikens and Madsen 1986:151). The prehistoric cultural chronology of the study area can be divided into the Paleo-Indian or Pre-Archaic period (10,000-7,500 B.C.); the Archaic period - which is further subdivided into the Early (7,500-4,000 B.C.), Middle (4,0002,000 B.C.), and Late Archaic (2,000 B.C.-A.D. 650) periods; the Late Prehistoric period (A.D. 650-1200), which includes the Fremont Culture; and the Protohistoric period (A.D. 1200-1650), terminating at the onset of Euro-American contact (Aikens 1983:169-176; Grady 1984:20-52; Aikens and Madsen 1986:149-160; Jennings 1978:17-240, 1986:114-116; Marwitt 1986:161-172). Details regarding the prehistory and ethnography of the region are presented in the Class I overview (Moeller et al. 1993) and are not repeated here.

\subsection{EURO-AMERICAN HISTORY}

Between 1820 and 1825, many explorers and fur trappers passed through the Green River country of northwestern Utah and southwestern Colorado. However, the first documented fur trade expedition to have entered the Little Hole and Browns Hole areas was that of General William Henry Ashley in 1825, who led an expedition down the Green River by way of Flaming Gorge. It was not until Ashley's party floated the river that Browns Hole, later named Browns Park, became well known as a major fur trade center. Ashley reported seeing large camps of 1,000 or more Native Americans centered on the riverbanks in Lower Browns Hole (Tennent 1981:8-9). The camps most likely were occupied by Ute and Shoshone, although there are reports of Blackfeet, Sioux, Cheyenne, Arapaho, and Navajo (Eddy et al. 1982:24). Fur trappers and miners from Browns Hole also frequented Little Hole, initially referred to as Little Browns Hole (Johnson n.d.; Kouris 1988:33).

From 1826 through 1840, Browns Hole maintained a flourishing fur trade business (Tennent 1981:9; Eddy et al. 1982:28-29). The valley was known as an advantageous spot for the trappers to winter because the weather was mild and the valley was centrally located on all the westward fur trading routes (Eddy et al. 1982:32). Browns Hole became the home 
of an important fur trade center, Fort Davy Crockett. It is not known in what year the fort was established, although a fort in Lower Browns Hole was mentioned as early as 1832. By 1837, the partners Phillip Thompson, Prewitt Sinclair, and William Craig were operating a fur trade business out of Fort Davy Crockett (Eddy et al. 1982:35). The fort was described by Thomas Farnum in 1839, as he and his party passed through the area on an expedition headed for Oregon, as "a hollow square of one story log cabin, with roofs and floors of mud construction ... surrounded by skin lodges belonging to white trappers and Indians ..." (Eddy et al. 1982:41). It was the first American settlement in the Browns Hole area and the principal economic and "social center of the Rocky Mountains" (Tennent 1981:9). Dr. F.A. Wislizenus and his party of fur trappers had a different impression of the fort: "... The fort itself is the worst thing of the kind that we have seen on our journey. It is a low, one story building, constructed of wood and clay ... instead of cows, the fort had some goats ... the whole establishment appeared somewhat poverty-stricken ..." (Tennent 1981:11). Apparently, the fort had this effect on many fur trappers because it was also known as Fort Misery (Tennent 1981:11; Eddy et al. 1982:42).

The fort had many visitors during its existence. From 1838 to 1839 , Kit Carson, Bill Owens, and many others trapped animals for the fort. By 1840, Fort Davy Crockett was abandoned, perhaps because of a breakdown in the partnership operating the fort and a related skirmish with Sioux that resulted in violence (Tennent 1981:13-14). In the 1840s, the great fur trade of the West began to decline. Although small-scale fur trading continued for several years in Browns Hole, a new way of life was gradually taking over in the valley.

During the 1840s and 1850s, Browns Hole seems to have had no permanent residents. However, many people apparently traveled through the area on their way to the gold rush in California, and others continued trapping after the abandonment of Fort Davy Crockett (Tennent 1981:17-18). Samuel Bassett and Warren D. Parsons and his wife were the first to have arrived in the area around 1842, searching for a place to farm and ranch (Tennent 1981:18). The John Wesley Powell expedition floated through Browns Hole in 1869, changing the name to Browns Park, as it is known today (Eddy et al. 1982:54). By the 1860s, the great cattle drives across the West had commenced, and the reputation of Browns Park for mild winters resulted in its continued use as an ideal wintering spot for cattlemen and their animals. This reputation also facilitated the settling of the valley by many ranchers and their families, who were intent on making Browns Park their permanent home (Norman and Merrill 1981:12; Eddy et al. 1982:55).

The cattle business in Browns Park included rustling and the employment of outlaws, two aspects that gave Browns Park a darker reputation as a lawless place. The settlers, however, viewed cattle rustling as acceptable. They believed that the larger cattle operations were too greedy, and, therefore, the small family ranching outfits felt justified in rustling cattle from the larger ones (Tennent 1981:24-25). Outlaws were given the opportunity for employment at any Browns Park ranch, as long as they did not take another person's life. The settlers held life as sacred, and they did not allow murder; anyone suspected of killing another human being had broken a very serious code of ethics in Browns 
Park (Tennent 1981:26). Some infamous persons known to have spent time in Browns Park include Butch Cassidy and Tom Horn (Tennent 1981:35-41).

One of the first permanent residents in Browns Park was Juan Jose "Mexican Joe" Herrera, who eventually built a cabin on the east bank of the Green River in Lower Browns Park. Herrera was known for his activism in such organizations as the White Caps, a group that resisted Anglo land encroachment in New Mexico, and the Knights of Labor, in which he was a district organizer for the union (Tennent 1981:26-27). Dr. John Parsons, who was the son of Warren Parsons, built a cabin near the mouth of Sears Creek. Parsons, the postmaster for the Browns Park post office, also constructed the first ferry across the Green River near his home. The Doc Parsons Cabin was one of the oldest known buildings in Browns Park. It was added to the National Register of Historic Places in 1976 but was destroyed by fire in 1978 (Tennent 1981:30). Expert cattle rancher Jesse S. Hoy and his family were also early inhabitants of the area who eventually settled there permanently (Tennent 1981:28). In the late 1870s and early 1880s, the Browns Park population increased steadily, and small cabins and ranch buildings began to dot the landscape all across the valley and on the riverbanks. In 1876, Charlie Crouse moved into Browns Park and established his reputation for raising choice horses, which he raced. He later founded the small settlement of Bridgeport, where he constructed the first bridge across the Green River in Browns Park (Tennent 1981:30-32). Other Browns Park residents who lived and ranched on the land adjacent to the river were the Allens, Taylors, Watsons, Wilsons, Warrens, Flynns, Carrs, Buffhams, and many others (Kouris 1988).

An important landmark in the life of Browns Park residents was the Lodore School, or Lodore Hall. Constructed in 1911 in Lower Browns Park, the school was apparently "... one of the finest schoolhouses in Moffat County [Colorado]..." (Kouris 1988:159). In addition to providing an education for Browns Park children, the school had other functions that were important to the community. It became one of the social centers of the valley, and "... meetings, welcome and farewell parties, baby showers, quilting bees, anniversary celebrations, and much more ..." took place at the school throughout its history (Kouris 1988:164). The school was reinforced with steel beams in the walls and ceiling in the 1920s, specifically for safety during the lively dances that took place there. Under the auspices of long-time Browns Park resident Marie Taylor Allen, the structure was placed on the National Register in 1975 and continues to host dances until this day (Kouris 1988:164,279).

John Jarvie moved to Browns Park in 1880, soon after marrying Nellie Barr in Rock Springs, Wyoming. The couple first opened a general store and trading post, where they sold "... everything from Indian flour, through new saddles, boots, wagon supplies, even had a pile of tepee pole for the Indians stacked outside ..." (Tennent 1981:48). The Jarvies also sold liquor at the store, and it soon developed into the social center of Browns Park - apparently being the only store for 70 miles (Tennent 1981:48). At the death of Doc Parsons in 1881, John Jarvie took over the job as postmaster, a job he kept for six years. Jarvie also took over operation of the ferry, which was rebuilt at his ranch from its previous location at Doc Parsons Cabin. Jarvie was apparently quite ambitious; he is reported to have been in mining, livestock, and land investments in addition to his store and ferry. A man of musical 
talent, who also loved literature and athletics, Jarvie was a very well-liked, esteemed entrepreneur and a dear friend to residents in Browns Park (Tennent 1981:51-63). In 1909, John Jarvie was murdered by two thieves, one of whom Jarvie had previously employed in his store. His death was a shock and an outrage in Browns Park, and nearly all of the residents joined to assist his sons in their search for the murderers, although they were never apprehended (Tennent 1981:80-89). The Jarvie Ranch changed ownership several times over the next several decades. In 1977, Esther Campbell, the final private owner of Jarvie Ranch, sold the ranch to the Nature Conservancy to save it from falling into the hands of commercial developers. The Nature Conservancy leased the land to the BLM, which purchased the historic Jarvie Ranch in 1981 and is responsible for its current restoration and preservation (Tennent 1981:90-93). That same year, the ranch was accepted for inclusion on both the Utah State Register and the National Register.

A small amount of mineral or ore mining was taking place along with the ranching business. Although no adequate records are available regarding how much or what type of ore existed in the area, placer mines in Little Hole, Red Creek Canyon, and Jesse Ewing Canyon of Browns Park were frequently mined. Jesse Ewing and John Jarvie were known to prospect for copper and other ores as well as for gold (Norman and Merrill 1981:20-23; Mehls 1985:110-112). Wade and Curtis, who had established a ranch near the Gates of Lodore Canyon, were the only prospectors to discover placer gold in the Green River in the 1930s. Uranium was found in Red Creek Canyon by Bill Allen, a long-time Browns Park resident (Mehls 1985:113).

Farming existed in Browns Park, but on a small scale until irrigation ditches were constructed along the Green River in the early 1900s. These ditches opened up the land for alfalfa, grain, and root crops (Moeller et al. 1993:25). Corn and wheat were also cultivated in the area, but these crops required large-scale irrigation to be at all profitable (Mehls 1985:119). As a result, cattle ranching remained the predominant economy.

During the 1880s, the sheepherding industry moved into Browns Park. Although it caused conflicts with cattle ranchers, sheepherding was a lucrative business because sheep provided a wider variety of end products than did cattle. Many Browns Park residents began to tend sheep once they learned of its increased economic stability (Mehls 1985:73). In the 1890s, the Browns Park Cattle Association was formed to stop the encroachment of sheep on the cattle range. Violence was prevalent as the cattleman forced the sheepherders out of the area, often in bloody skirmishes. In addition, throughout the next several decades, hundreds of sheep were slaughtered by groups of cattle ranchers. The "Sheep War" of 1920, in which some of the sheepherders were murdered, prompted the Colorado State Police to end the "war," although battles continued in the county courts (Mehls 1985:121-124).

Changes at Browns Park took place slowly over the entire first half of the 20th century. The U.S. Forest Service established Ashley National Forest and Routt National Forest in 1905, implementing regulations and a permit system for cattle grazing (Mehls 1985:119). As a result, the cattle industry began to decline in Browns Park as it had in other areas of the West. Some descendants of the original Browns Park families continued to raise 
cattle as they always had, but many others were forced to sell their land and move to nearby towns (Norman and Merrill 1981:17). In the middle of the 20th century, changes became more rapid. Telephone lines were brought into the area, dirt roads became paved highways, and government agencies constructed offices and began to establish campgrounds and other recreational facilities to encourage tourism. By the 1970s, $49 \%$ of Browns Park belonged to the U.S. Fish and Wildlife Service, $30 \%$ to the BLM, $10 \%$ to the state of Utah, and $8 \%$ to National Park Service; only the remaining 3\% is privately owned (Kouris 1988:276). 


\section{RESEARCH DESIGN AND METHODOLOGY}

The Green River field study entailed relocating and describing the condition of particular sites within the study area that might be impacted by power-related dam operations. The study area is defined as the river corridor, with a minimum width of $0.5 \mathrm{mi}$ from each riverbank and a maximum width of the distance from the river (if exceeding $0.5 \mathrm{mi}$ ) to the place where the elevation reaches $60 \mathrm{ft}$ above water level. The work completed for the Class I overview was critical in developing the research design because it familiarized the field study team with the findings of all known surveys previously undertaken in the study area (Section 4.1) and provided a complete inventory of recorded sites (Appendix A, Table A.1). The team was therefore familiar with the locations, types, and, in some cases, past condition of sites before entering the field. For purposes of assessing potential impacts, the team was able to identify which sites should be relocated on the basis of their distance to water, elevation, and geomorphic setting. A more detailed description of the field study design implemented June 15-19, 1992, is provided in Section 4.2.

\subsection{PREVIOUS FIELD SURVEYS}

The earliest archaeological explorations in the Green River Basin were performed by several researchers working with early government expeditions that passed through southwestern Wyoming and northeastern Utah in the 1870s on their way to Yellowstone National Park. In the late 1930s and early 1940s, the first major research projects were carried out by Burgh and Scoggin in Dinosaur National Monument and the Castle Park area of northeastern Utah (Eddy et al. 1982).

In 1951, the University of Colorado, under the direction of R.H. Lister, performed several major archaeological investigations in the Castle Park area. These investigations prompted the discovery of Hell's Midden, a multicomponent stratified rockshelter site, and helped establish the cultural chronology of the Browns Park and Dinosaur National Monument area. It was here that a distinct Fremont culture was first identified (Aikens and Madsen 1986). The University of Colorado continued to work in the region in the mid-1960s. During these investigations, Deluge Shelter was located and excavated. This site was reported to have contained datable material from Paleo-Indian through Protohistoric periods, further aiding the development of a cultural chronology for the area (Breternitz 1965, 1970; Leach 1970). The discovery and excavation of Swelter Shelter, also in Dinosaur National Monument, provided additional data concerning this chronology (Leach 1970).

Beginning in the late 1970s and early 1980s, Little Hole and Browns Park underwent several major archaeological surveys along the Green River. Numerous smaller compliance surveys also took place, thus increasing the amount of data available concerning regional and local prehistory and history. The following surveys covered areas along the Green River that are included in the study area. 
Small portions of the Little Hole area on the south side of the river were surveyed by BLM in the mid-1970s on an individual project basis. These small-scale surveys were documented by single-page site reports (e.g., Harper 1978). Subsequently, the area was surveyed in large part by the U.S. Forest Service, which owns the land on the north side of the river, and by the MESA Corporation for the Peaking Power Project (Norman and Merrill 1981). The MESA Corporation survey was a $40 \%$ sampling survey conducted on areas along the river from Flaming Gorge Dam to the northern boundary of Dinosaur National Monument at the Gates of Lodore. In the Little Hole area, the survey discovered eight prehistoric sites (42DA204, 42DA222, 42DA223, 42DA224, 42DA226, 42DA275, 42DA334, 42DA335), two historic sites (42DA227, 42DA333), and one site containing both a prehistoric and historic component (42DA332). The survey also relocated one previously known prehistoric site (42DA40), located on the south bank, which was originally discovered in 1974 during one of the small-scale BLM surveys (Tucker 1974). The U.S. Forest Service conducted several surveys in conjunction with the Dripping Springs and Little Hole campgrounds and the Mann Bench development within Ashley National Forest. These surveys identified five prehistoric sites (42DA166, 42DA168, 42DA174, 42DA175, 42DA176), two historic sites (42DA167, 42DA211), and numerous isolated artifacts (McFadden 1978; McFadden and Worthington 1978; Oprandy 1984; Johnson n.d.). Two additional prehistoric lithic scatters (42DA387, 42DA388) were found during a survey for the Western Geophysical Seismic Line (Moore 1985) (Table 3; Figure 2).

Upper Browns Park begins at the terminus of Red Canyon, just east of the mouth of Red Creek, and continues downstream to Swallow Canyon. In a 1976 survey conducted by Richard Fike for BLM, covering 850 acres in Upper Browns Park, 14 sites were identified, four of which are in the study area. Only two of those sites are in noncanyon areas less than $60 \mathrm{ft}$ above the river: a prehistoric campsite (42DA61), now eligible for inclusion on the National Register, and a lithic workshop (42DA69) (Fike 1976). The BLM also conducted smaller surveys in Upper Browns Park, similar to those in the Little Hole area. One such survey located a prehistoric campsite (42DA52) south of the river and west of the Bridge Hollow Campground (Tucker 1976). Two prehistoric sites (42DA202, 42DA203) were identified near the mouth of Tolivers Creek in a section of the 600-acre survey for the Utah State Division of Wildlife (Madsen and Sargent 1979). The MESA Corporation survey for the Peaking Power Project was responsible for discovering and recording four prehistoric sites (42DA228, 42DA241, 42DA336, 42DA339) and three historic sites (42DA337, 42DA338, 42DA342). The survey also relocated a prehistoric site previously recorded by the BLM in 1976 (42DA69; see above) (Norman and Merrill 1981).

In 1981, a seismic line was surveyed in the Clay Basin area, but no cultural resources were encountered (Cook 1981). Several pipeline projects required surveys to be performed in the areas between the Jarvie Ranch and the upstream end of Swallow Canyon (McEnany 1981; Woodward-Clyde 1982, 1983, 1985; Creasman 1985a, 1985b; Newberry 1985; Tucker 1986). The MAPCO pipeline survey recorded one prehistoric site (42DA196) on the east bank of the Green River within the current study area (McEnany 1981). Surveys conducted for the Chevron Carbon Dioxide and Phosphate Slurry pipeline discovered two 
TABLE 3 Previous Field Surveys in the Little Hole Area

\begin{tabular}{|c|c|c|c|c|c|c|c|c|}
\hline Project Name & Year & $\begin{array}{c}\text { Area } \\
\text { Surveyed }\end{array}$ & $\begin{array}{l}\text { Percent } \\
\text { Sampled }\end{array}$ & $\begin{array}{l}\text { Survey } \\
\text { Code }^{a}\end{array}$ & $\begin{array}{l}\text { Sampling } \\
\text { Procedures }\end{array}$ & $\begin{array}{l}\text { Number } \\
\text { of Sites } \\
\text { Recorded }\end{array}$ & $\begin{array}{l}\text { Number } \\
\text { in ANL } \\
\text { Database }^{b}\end{array}$ & Reference \\
\hline $\begin{array}{l}\text { Bureau of Land Management } \\
\text { Antiquities Site Inventory } \\
\text { Form for Site } 42 D A 40\end{array}$ & 1974 & $100 \mathrm{yd} \times 200 \mathrm{yd}$ & $100 \%$ & 3 & $\begin{array}{l}\text { Surface inventory/survey } \\
\text { of the complete site; not } \\
\text { plotted on figure. }\end{array}$ & 1 & 7FG-1 & Tucker (1974) \\
\hline $\begin{array}{l}\text { Archaeological Survey Report: } \\
\text { Dutch John Pinyon-Juniper } \\
\text { Conversion Project (July) }\end{array}$ & 1977 & Not specified & $100 \%$ & 3 & $\begin{array}{l}\text { Area surveyed in } \\
\text { transects spaced } 30 \mathrm{ft} \\
\text { apart. }\end{array}$ & 17 & $4 \mathrm{FG}-24$ & Watts (1977) \\
\hline $\begin{array}{l}\text { Archaeological Survey Report: } \\
\text { Dutch John Pinyon-Juniper } \\
\text { Conversion Project } \\
\text { (September) }\end{array}$ & 1977 & 200 acres & $100 \%$ & 3 & $\begin{array}{l}\text { Area divided into four } \\
\text { separate zones; surveyed } \\
\text { in parallel transects } \\
\text { spaced } 30 \mathrm{ft} \text { apart. }\end{array}$ & 8 & $4 \mathrm{FG}-27$ & Iacovetta (1977) \\
\hline $\begin{array}{l}\text { Cultural Resource Survey of } \\
\text { O.D. Ignacio to Sumas Line, } \\
\text { Dagget Co., Utah }\end{array}$ & 1978 & $9.43 \mathrm{mi}$ & $100 \%$ & 3 & $\begin{array}{l}\text { Walked transect along } \\
\text { existing pipeline outside } \\
\text { disturbed area. }\end{array}$ & 0 & $7 \mathrm{FG}-6$ & Harper (1978) \\
\hline $\begin{array}{l}\text { Cultural Resource Survey of } \\
\text { the Northwest Corporation } \\
\text { Pipeline Pinyon-Juniper } \\
\text { Pushover }\end{array}$ & 1978 & 20 acres & $100 \%$ & 3 & $\begin{array}{l}\text { Area divided into } \\
13 \text { separate units; } \\
\text { systematic survey; } \\
\text { not specified. }\end{array}$ & 3 & 4FG-28 & McFadden (1978) \\
\hline $\begin{array}{l}\text { Cultural Resource Survey for } \\
\text { the Little Hole Campground } \\
\text { Expansion and Mann Bench } \\
\text { Development }\end{array}$ & 1978 & Not specified & $100 \%$ & 3 & $\begin{array}{l}\text { Systematic transects; } \\
\text { not specified. }\end{array}$ & 3 & 4FG-34 & $\begin{array}{l}\text { McFadden and } \\
\text { Worthington } \\
\text { (1978) }\end{array}$ \\
\hline $\begin{array}{l}\text { Cultural Resources Survey of } \\
\text { the Flaming Gorge Peaking } \\
\text { Power Project }\end{array}$ & 1981 & $\begin{array}{l}30.2 \mathrm{mi} \times 400 \mathrm{ft} \\
\text { (approx.) }\end{array}$ & $40 \%$ & 2 & $\begin{array}{l}200 \text {-ft-wide corridor on } \\
\text { either side of the Green } \\
\text { River from Flaming } \\
\text { Gorge Dam to boundary } \\
\text { of Dinosaur National } \\
\text { Monument; } 50 \text {-ft zigzag } \\
\text { transects. }\end{array}$ & $11(29)^{\mathrm{c}}$ & $1 F G-7$ & $\begin{array}{l}\text { Norman and } \\
\text { Merrill (1981) }\end{array}$ \\
\hline
\end{tabular}


TABLE 3 (Cont.)

\begin{tabular}{|c|c|c|c|c|c|c|c|c|}
\hline Project Name & Year & $\begin{array}{c}\text { Area } \\
\text { Surveyed }\end{array}$ & $\begin{array}{l}\text { Percent } \\
\text { Sampled }\end{array}$ & $\begin{array}{l}\text { Survey } \\
\text { Code }^{a}\end{array}$ & $\begin{array}{l}\text { Sampling } \\
\text { Procedures }\end{array}$ & $\begin{array}{l}\text { Number } \\
\text { of Sites } \\
\text { Recorded }\end{array}$ & $\begin{array}{l}\text { Number } \\
\text { in ANL } \\
\text { Database }^{b}\end{array}$ & Reference \\
\hline Mann Bench Borrow Site & 1984 & 1 acre & $100 \%$ & 3 & $\begin{array}{l}\text { Intensive survey; not } \\
\text { specified. }\end{array}$ & 0 & 4FG-35 & Oprandy (1984) \\
\hline $\begin{array}{l}\text { Archaeological Survey of } \\
\text { Three Seismic Lines near } \\
\text { Dutch John in Ashley } \\
\text { National Forest (Line GC4-2) }\end{array}$ & 1984 & $\begin{array}{l}15 \mathrm{mi} \times 200 \mathrm{ft} \\
\text { (approx.) }\end{array}$ & $100 \%$ & 3 & $\begin{array}{l}200 \text {-ft-wide seismic line } \\
\text { corridor; pedestrian } \\
\text { survey } 15 \mathrm{~m} \text { apart, } \\
\text { perpendicular to the } \\
\text { seismic line. }\end{array}$ & 7 & 7FG-2 & Moore (1985) \\
\hline $\begin{array}{l}\text { Archaeological Inventory of } \\
\text { One Seismic Line on Goslin } \\
\text { Mountain and in Clay Basin }\end{array}$ & 1990 & $7 \mathrm{mi} \times 100 \mathrm{ft}$ & $100 \%$ & 3 & $\begin{array}{l}\text { 100-ft right-of-way } \\
\text { surveyed in zigzag } \\
\text { transects. }\end{array}$ & 0 & 4FG-21 & Billat (1990) \\
\hline $\begin{array}{l}\text { National Register of Historic } \\
\text { Places Inventory Site Form for } \\
\text { Site 42DA211 }\end{array}$ & n.d. ${ }^{d}$ & 0.10 acre & $100 \%$ & 3 & $\begin{array}{l}\text { Surface inventory/survey } \\
\text { of the complete site; not } \\
\text { plotted on figure. }\end{array}$ & 1 & 7FG-3 & Johnson (n.d.) \\
\hline
\end{tabular}

a Survey code: 0 , type of survey not specified in report or data incomplete; 1 , unsystematic survey - includes random walkovers, compilations, etc.; 2 , sampling methods used; 3 , intensive survey, usually covering $100 \%$ of area.

b Survey number in ANL (Argonne National Laboratory) database; corresponds to numbered survey areas on Figure 2.

c Number in parentheses is total number of sites recorded during survey; first number denotes number of sites in the specific area.

d n.d. indicates no date; survey or report date unknown. 


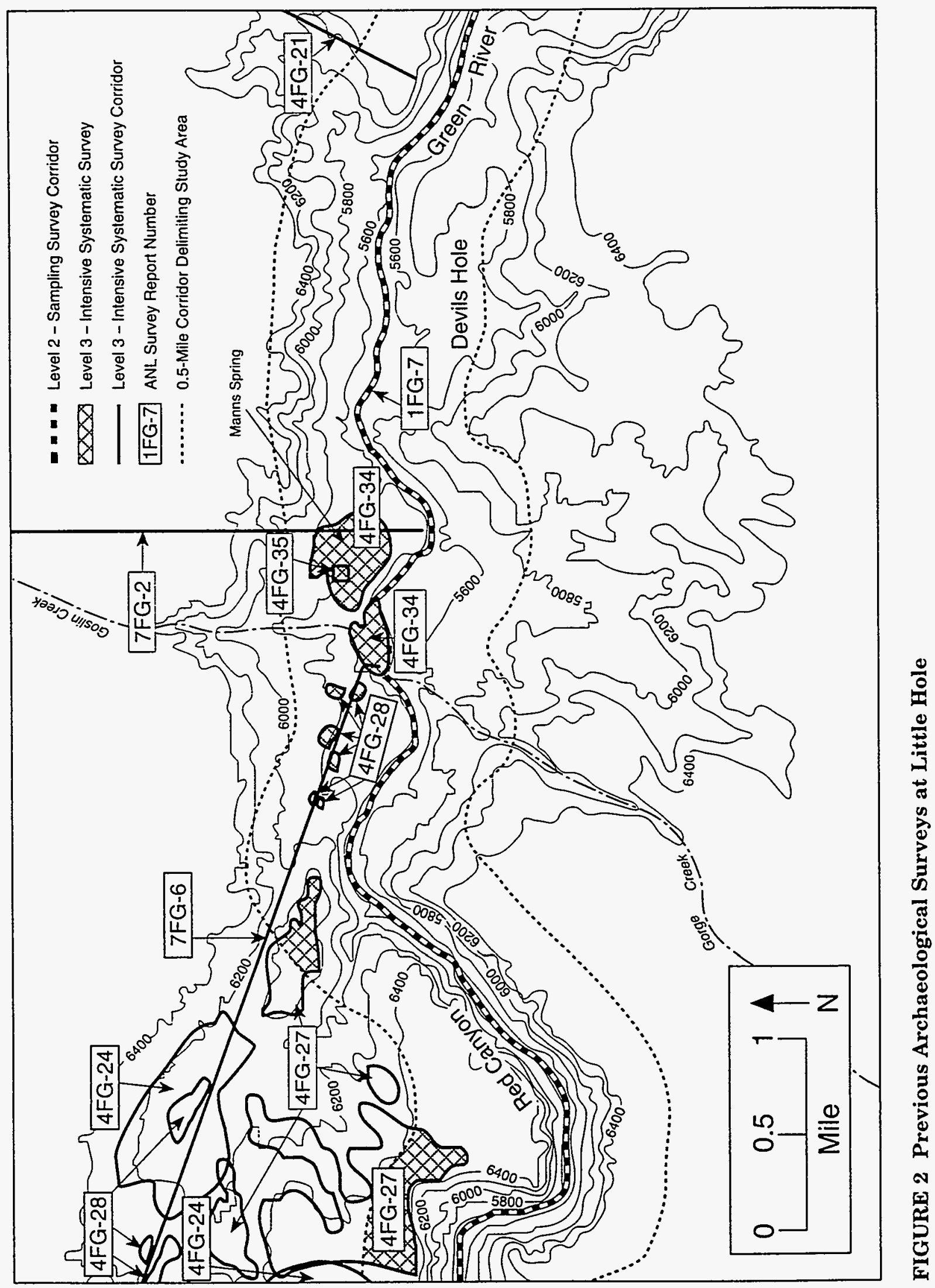


prehistoric campsites (42DA393, 42DA402), the Crouse Irrigation Ditch (42DA394), and a stagecoach route (42DA395); prehistoric site 42DA61 was rerecorded (Woodward-Clyde 1985; Newberry 1985). The Questar North-South Pipeline project discovered five prehistoric campsites located within the study area (42DA485, 42DA486, 42DA487, 42DA488, 42DA489) and relocated two sites (42DA196, 42DA394) (McKibbin 1988, 1992).

In 1986, a survey performed by the Utah Division of State History and the BLM for a chaining and seeding project recorded 34 sites. Twelve of these sites were outside the current study area, and fourteen were in canyon areas over $200 \mathrm{ft}$ above the river; however, eight of the prehistoric sites were found within the study area, east of Sears Creek and west of the Green River. These sites included six campsites (42DA420, 42DA422, 42DA423, 42DA424, 423DA436, 42DA438), one lithic quarry (42DA421), and one surficial scatter (42DA419) (Lindsay 1986a-b) (Table 4; Figures 3 and 4).

Lower Browns Park begins from the point at which the Green River leaves Swallow Canyon and meanders through the bottomland to the Gates of Lodore Canyon in Moffat County, Colorado. The Utah State Division of Wildlife Resources survey reported no cultural resources in survey areas east or west of the mouth of Crouse Creek and none in a survey area near the Colorado border (Madsen and Sargent 1979). During an extensive survey of several bottomlands along the Green River, Meyer and Riches (1979) discovered three prehistoric sites (5MF840, 5MF841, 5MF842) and relocated one previously known prehistoric site (5MF688) containing rock art. This survey covered areas within Flynn, Warren, Nelson, Grimes, and Carr Bottoms, but did not address the historic sites along the riverbanks. An additional survey of about half of Allen Bottom was taken in 1980 by the BLM, but no cultural resources were encountered (Hansen 1980). The MESA Corporation survey for the Peaking Power Project identified 11 sites along the river. The prehistoric sites consisted of one campsite (5MF1230) and two surficial lithic scatters (5MF1228, 5MF1238). In addition, the survey documented eight historic sites located on the edge of the lowest terrace of the river (5MF1229, 5MF1231-1237) (Norman and Merrill 1981). In 1980, the U.S. Fish and Wildlife Service, current owners of the land in the Lower Browns Park study area, ordered that a mitigation program be in place for the proposed location of historic Fort Davy Crockett due to the erosion of the bank near Harry Hoy Bottom. An excavation of the site (5MF605) was completed in 1981 (Eddy et al. 1982) (Table 5; Figures 5, 6, and 7).

In summary, 26 archaeological surveys are known to have been conducted within the study areas of Little Hole, Upper Browns Park, and Lower Browns Park. Approximately 30\% of these areas have been subject to intensive archaeological surveying. The entire stretch of river, close to the banks, has been subject to a random sampling survey by the MESA Corporation Peaking Power Project.

\subsection{FIELD STUDY DESIGN}

For this field study, data were collected from archaeological sites in the study area to assess potential impacts to these sites. The study entailed relocation of previously 
TABLE 4 Previous Field Surveys in the Upper Browns Park Area

\begin{tabular}{|c|c|c|c|c|c|c|c|c|}
\hline Project Name & Year & $\begin{array}{c}\text { Area } \\
\text { Surveyed }\end{array}$ & $\begin{array}{l}\text { Percent } \\
\text { Sampled }\end{array}$ & $\begin{array}{l}\text { Survey } \\
\text { Cocle" }\end{array}$ & $\begin{array}{l}\text { Sampling } \\
\text { Procedures }\end{array}$ & $\begin{array}{l}\text { Number } \\
\text { of Sites } \\
\text { Recorded" }\end{array}$ & $\begin{array}{l}\text { Number } \\
\text { in ANL } \\
\text { Databasec }\end{array}$ & Reference \\
\hline $\begin{array}{l}\text { Archaeological Investigations } \\
\text { in Browns Park Vernal } \\
\text { District }\end{array}$ & 1976 & $\begin{array}{l}850 \text { acres; } \\
175 \mathrm{yd} \times 75 \mathrm{yd} \\
\text { and } 50 \mathrm{ft} \times 50 \mathrm{ft}\end{array}$ & $100 \%$ & 3 & $\begin{array}{l}\text { Class II survey, not } \\
\text { specified; Sites } 42 \mathrm{DA} 56 \\
\text { and } 42 \mathrm{D} A 59, \text { and } \\
421) \wedge 61 ; \text { surfice } \\
\text { inventory/survey of } \\
\text { complete site; not } \\
\text { plotted on figure. }\end{array}$ & $4(14)$ & $6 F G-2 a, 2 b$ & Fike (1976) \\
\hline $\begin{array}{l}\text { Bureau of Land Management } \\
\text { Antiquities Site Inventory } \\
\text { Form for Site } 42 \mathrm{DA} 52\end{array}$ & 1976 & $100 \mathrm{ft}^{2}$ & $100 \%$ & 3 & $\begin{array}{l}\text { Surface inventory/ } \\
\text { survey of the complete } \\
\text { site; not plotted on } \\
\text { figure. }\end{array}$ & 1 & $7 F G-5$ & Tucker (1976) \\
\hline John Jarvie Ranch & 1978 & 35.4 acres & $N S^{d}$ & & Historic site inventory. & 1 & $6 \mathrm{FG}-3$ & Tennent (1981) \\
\hline $\begin{array}{l}\text { Archaeological Inventory of } \\
\text { the Browns Park Land } \\
\text { Exchange }\end{array}$ & 1979 & 600 acres & NS & 2 & $\begin{array}{l}\text { Transects spaced } 50 \text { to } \\
100 \mathrm{ft} \text { apart. }\end{array}$ & 2 & $2 F G-11$ & $\begin{array}{l}\text { Madsen and } \\
\text { Sargent (1979) }\end{array}$ \\
\hline $\begin{array}{l}\text { MAPCO Rocky Mountain } \\
\text { Liquid Hydrocarbons Pipeline }\end{array}$ & 1979 & $200-\mathrm{ft}$ corridor & $100 \%$ & 3 & Not specified. & $1 / 1 \mathrm{R}$ & 1GR-5 & McEnany $(1981)^{e}$ \\
\hline $\begin{array}{l}\text { Cultural Resources Survey of } \\
\text { the Flaming Gorge Peaking } \\
\text { Power Project }\end{array}$ & 1981 & $\begin{array}{l}30.2 \mathrm{mi} \times 400 \mathrm{ft} \\
\text { (approx.) }\end{array}$ & $40 \%$ & 2 & $\begin{array}{l}200 \text {-ft-wide corridor on } \\
\text { either side of the Green } \\
\text { River from Flaming } \\
\text { Gorge Dam to boundary } \\
\text { of Dinosaur National } \\
\text { Monument; } 50 \text {-ft zigzag } \\
\text { transects. }\end{array}$ & $7(29)$ & 1FG-7 & $\begin{array}{l}\text { Norman and } \\
\text { Merrill (1981) }\end{array}$ \\
\hline $\begin{array}{l}\text { Archaeological Reconnais- } \\
\text { sance of the Clay Basin } \\
\text { Seismic Project }\end{array}$ & 1981 & $16 \mathrm{mi} \times 50 \mathrm{ft}$ & $100 \%$ & 3 & Single zigzag transect. & 0 & 6FG-1 & Cook (1981) \\
\hline $\begin{array}{l}\text { PLT Engineering, Inc., } \\
\text { Chevron } \mathrm{CO}_{2} \mathrm{PO}_{4} \text { Pipeline } \\
\text { Corridors }\end{array}$ & 1985 & $\begin{array}{l}8,500 \mathrm{ft} \times 50 \mathrm{ft} \\
1,200 \mathrm{ft} \times 25 \mathrm{ft} \\
\text { in } 7 \text { areas }\end{array}$ & $100 \%$ & 3 & Single zigzag transect. & $1 \mathrm{R}$ & 4FG-22 & Creasman (1985b) \\
\hline
\end{tabular}




\section{TABLE 4 (Cont.)}

\begin{tabular}{|c|c|c|c|c|c|c|c|c|}
\hline Project Name & Year & $\begin{array}{c}\text { Area } \\
\text { Surveyed }\end{array}$ & $\begin{array}{l}\text { Percent } \\
\text { Sampled }\end{array}$ & $\begin{array}{l}\text { Survey } \\
\text { Code }^{\text {II }}\end{array}$ & $\begin{array}{l}\text { Sampling } \\
\text { Procedures }\end{array}$ & $\begin{array}{c}\text { Number } \\
\text { of Sites } \\
\text { Recorded }\end{array}$ & $\begin{array}{l}\text { Number } \\
\text { in ANL } \\
\text { Database }^{c}\end{array}$ & Reference \\
\hline $\begin{array}{l}\text { PLT Engineering, Inc., } \\
\text { Borrow Area for Chevron } \\
\mathrm{CO}_{2} \mathrm{PO}_{4} \text { Pipeline }\end{array}$ & 1985 & $340 \mathrm{ft} \times 140 \mathrm{ft}$ & $100 \%$ & 3 & $\begin{array}{l}\text { Systematic transects } \\
\text { spaced } 50 \mathrm{ft} \text { apart. }\end{array}$ & $\mathbf{0}$ & 4FG-23 & Creasman (1985a) \\
\hline $\begin{array}{l}\text { PLT Engineering, Inc., } \\
\text { Borrow Pit for Chevron } \\
\mathrm{CO}_{2} / \mathrm{PO}_{4} \text { Pipeline }\end{array}$ & 1985 & $\begin{array}{l}69,300 \mathrm{ft}^{2} \\
\text { (approx.) }\end{array}$ & $100 \%$ & 3 & $\begin{array}{l}\text { Surface inventory/ } \\
\text { survey of the complete } \\
\text { site; not plotted on } \\
\text { figure. }\end{array}$ & 1 & 7FG-7 & Newberry (1985) \\
\hline $\begin{array}{l}\text { Cultural and Paleontological } \\
\text { Resource Inventory ... } \\
\text { Chevron } \mathrm{CO}_{2} \mathrm{PO}_{4} \text { Pipeline } \\
\text { Corridors, Colorado, Utah, } \\
\text { and Wyoming }\end{array}$ & 1985 & $\begin{array}{l}200-f t \text { corridor } \\
\text { through Browns } \\
\text { Park Area }\end{array}$ & $100 \%$ & 3 & $\begin{array}{l}\text { Parallel transects } \\
\text { spaced } 30 \text { to } 50 \mathrm{ft} \\
\text { apart. }\end{array}$ & $3 / 1 R$ & 1GR-1 & $\begin{array}{l}\text { Woodward-Clyde } \\
(1985)^{f}\end{array}$ \\
\hline $\begin{array}{l}\text { Browns Park Chaining } \\
\text { Archaeological Survey } \\
\text { Preliminary Report }\end{array}$ & 1986 & $\begin{array}{l}466.5 \text { acres in } \\
12 \text { parcels }\end{array}$ & $100 \%$ & 3 & $\begin{array}{l}\text { Parallel transects } \\
\text { spaced a maximum of } \\
65 \mathrm{ft} \text { apart. }\end{array}$ & $22(34)$ & 2FG-12 & Lindsay (1986a) \\
\hline $\begin{array}{l}\text { Additional Browns Park } \\
\text { Chaining Archaeological } \\
\text { Survey Preliminary Report }\end{array}$ & 1986 & 315 acres & $100 \%$ & 3 & $\begin{array}{l}\text { Parallel transects } \\
\text { spaced a maximum of } \\
50 \mathrm{ft} \text { apart. }\end{array}$ & $0(17 / 2 R)$ & 2FG-12 & Lindsay (1986b) \\
\hline $\begin{array}{l}\text { Cultural Resource Inventory } \\
\text { of the Proposed Questar } \\
\text { North-South Pipeline Project }\end{array}$ & 1992 & 200-ft corridort' & $100 \%$ & 3 & $50 \mathrm{ft}$ transects. & $\begin{array}{c}5 / 2 \mathrm{R} \\
(24 / 18 \mathrm{R})\end{array}$ & $7 \mathrm{FG}-4$ & McKibbin (1992) \\
\hline
\end{tabular}

"Survey code: 0 , type of survey not specified in report or data incomplete; 1 , unsystematic survey - includes random walkovers, compilations, etc.; 2 , sampling methods used; 3 , intensive survey, usually covering $100 \%$ of area.

b Number in parentheses is total number of sites recorded during survey; first number denotes number of sites in the specific area. $R$ indicates rerecorded sites(s).

c Survey number in ANL database; corresponds to numbered survey areas on Figures 3 and 4.

"NS = not specified.

- Survey/site information also contained in Woodward-Clyde (1982), ANL database number 1GR-6; and Woodward-Clyde (1983), ANL database number 1GR-7.

Survey/site information also contained in Tucker (1986), ANL database number 1GR-2.

g The corridor is only $50 \mathrm{ft}$ wide along existing pipeline; the pipeline runs from Clay Basin to Fidlar Compressor Station. 


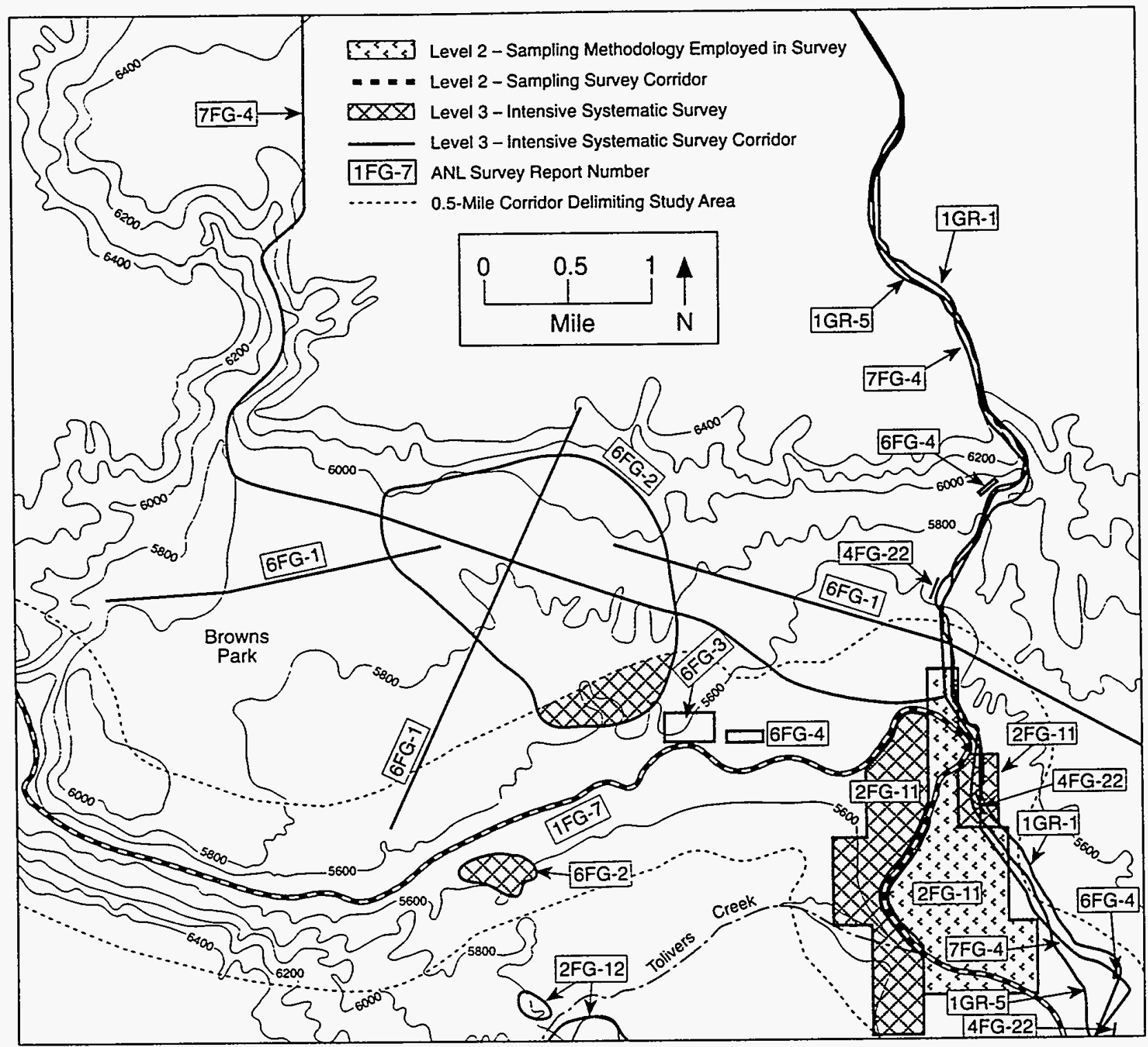

FIGURE 3 Previous Archaeological Surveys of Upper Browns Park: Map 1 


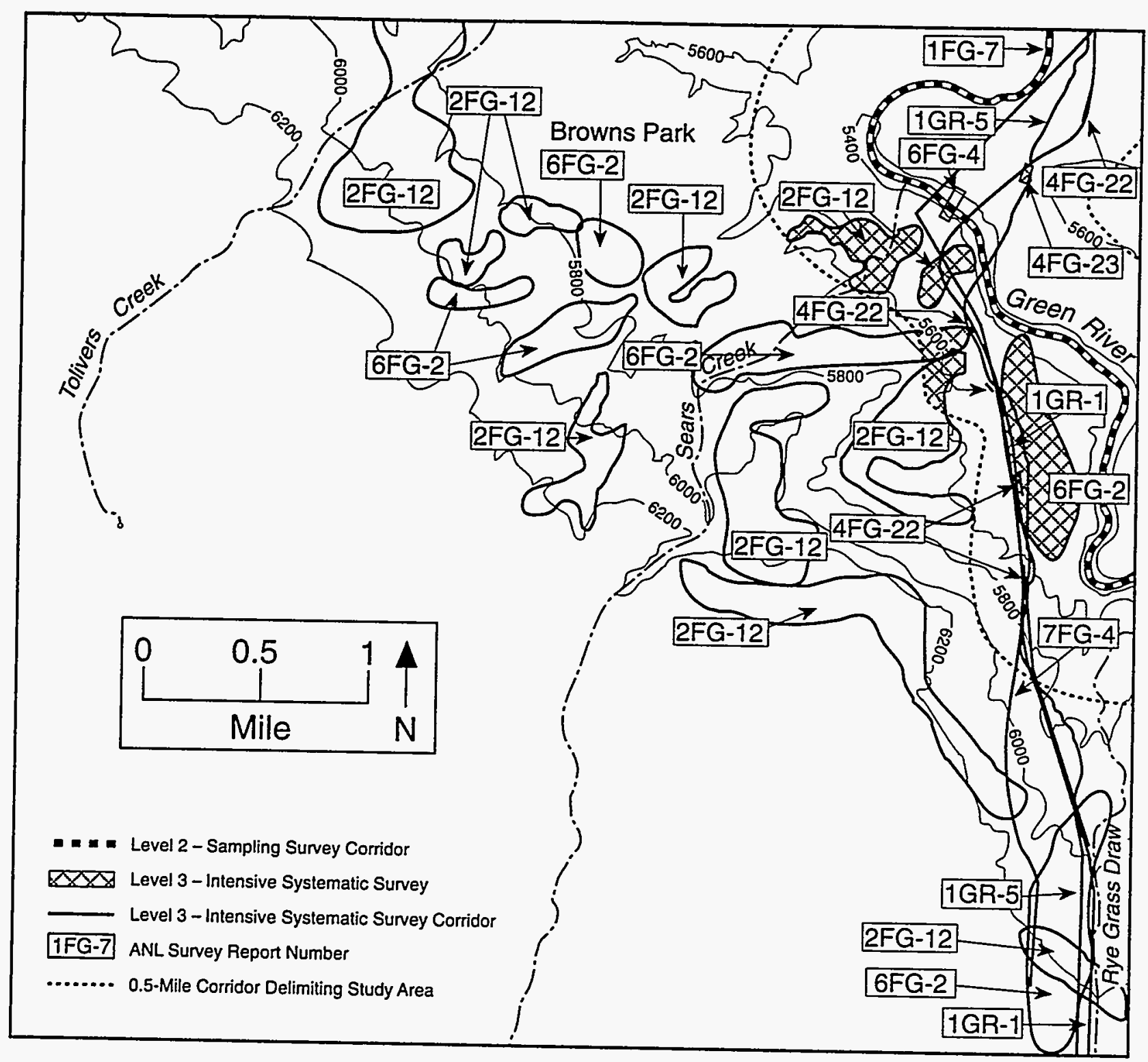

FIGURE 4 Previous Archaeological Surveys of Upper Browns Park: Map 2 
TABLE 5 Previous Field Surveys in the Lower Browns Park Area

\begin{tabular}{|c|c|c|c|c|c|c|c|c|}
\hline Project Name & Year & $\begin{array}{c}\text { Area } \\
\text { Surveyed }\end{array}$ & $\begin{array}{l}\text { Percent } \\
\text { Sampled }\end{array}$ & $\begin{array}{l}\text { Survey } \\
\text { Code }\end{array}$ & $\begin{array}{l}\text { Sampling } \\
\text { Procedures }\end{array}$ & $\begin{array}{l}\text { Number } \\
\text { of Sites } \\
\text { Recorded }^{b}\end{array}$ & $\begin{array}{c}\text { Number } \\
\text { in ANL } \\
\text { Database }^{c}\end{array}$ & Reference \\
\hline $\begin{array}{l}\text { Cultural Resource Survey, } \\
\text { Browns Park National } \\
\text { Wildlife Refuge }\end{array}$ & 1979 & 2,037 acres & $100 \%$ & 3 & $\begin{array}{l}\text { Parallel transects spaced } 40 \mathrm{ft} \\
\text { apart. }\end{array}$ & 2 & 2FG-10 & $\begin{array}{l}\text { Meyer and } \\
\text { Riches (1979) }\end{array}$ \\
\hline $\begin{array}{l}\text { Browns Park National } \\
\text { Wildlife Refuge Survey }\end{array}$ & 1980 & 140 acres & $100 \%$ & 3 & Not specified. & 0 & 2FG-13 & Hansen (1980) \\
\hline $\begin{array}{l}\text { Cultural Resources Survey } \\
\text { of the Flaming Gorge } \\
\text { Peaking Power Project }\end{array}$ & 1981 & $\begin{array}{l}30.2 \mathrm{mi} \times 400 \mathrm{ft} \\
\text { (approx.) }\end{array}$ & $40 \%$ & 2 & $\begin{array}{l}200 \text {-ft-wide corridor on either } \\
\text { side of the Green River from } \\
\text { Flaming Gorge Dam to boundary } \\
\text { of Dinosaur National Monument; } \\
50 \text {-ft zigzag transects. }\end{array}$ & $11(29)$ & 1FG-7 & $\begin{array}{l}\text { Norman and } \\
\text { Merrill (1981) }\end{array}$ \\
\hline
\end{tabular}

a Survey code: 0 , type of survey not specified in report or data incomplete; 1 , unsystematic survey - includes random walkovers, compilations, etc.; 2 , sampling methods used; 3 , intensive survey, usually covering $100 \%$ of area.

b Number in parentheses is total number of sites recorded during survey; first number denotes number of sites in the specific area.

c Survey number in ANL database; corresponds to numbered survey areas on Figures 5, 6, and 7. 


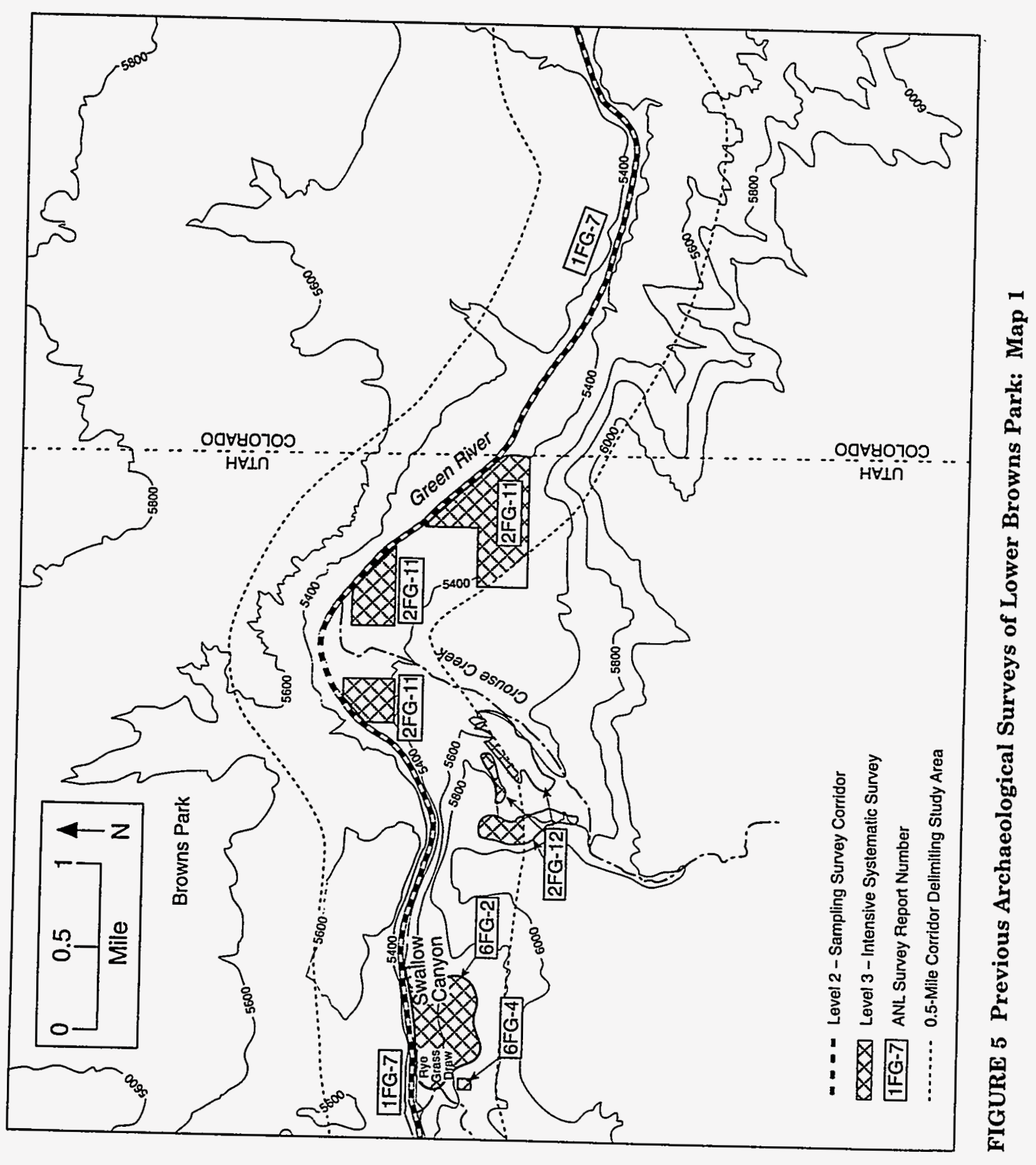




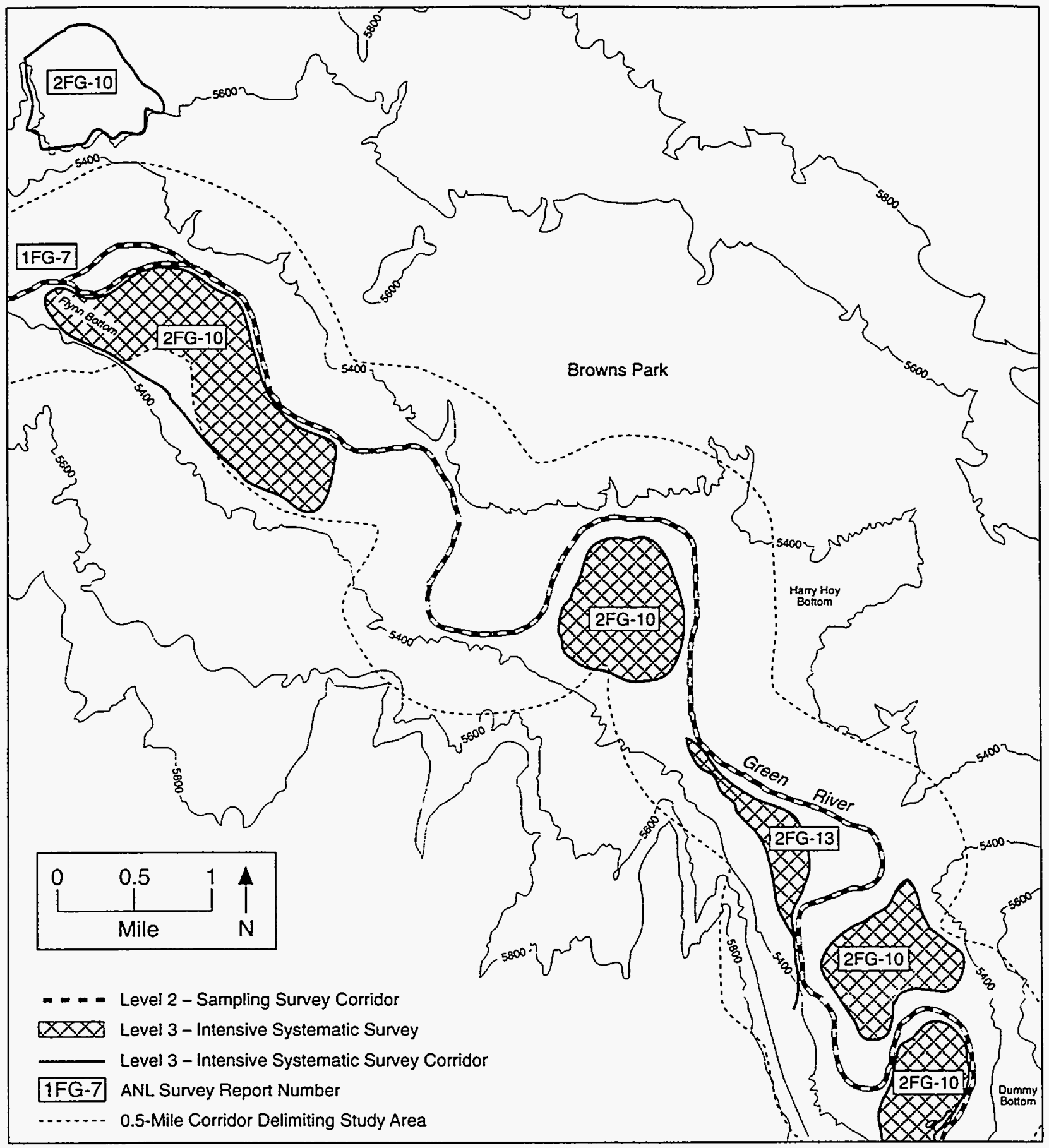

FIGURE 6 Previous Archaeological Surveys of Lower Browns Park: Map 2 


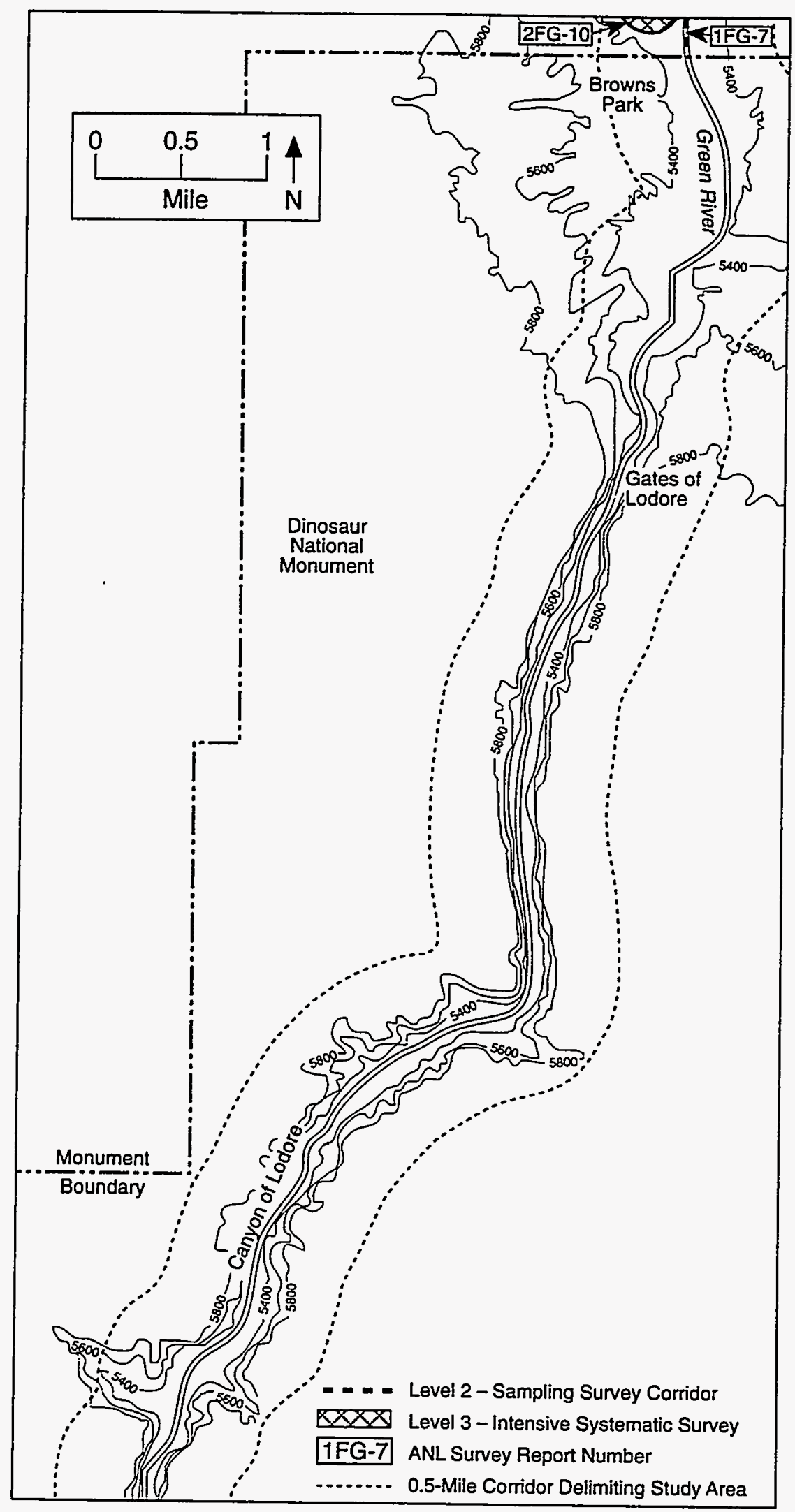

FIGURE 7 Previous Archaeological Surveys of Lower Browns Park: Map 3 
recorded sites (or discovery of unrecorded sites) in potentially affected areas (Section 4.2.1) and collection of information regarding the sites' geomorphic settings and current conditions.

\subsubsection{Area of Potential Effect}

Literature, file, and map searches were conducted for the Class I overview (Moeller et al. 1993). The topographic maps were a key element in defining the potentially affected area. The sites most likely to be impacted by hydropower generation, if impacted at all, were determined to be those closest to the river channel, on low terraces, and along tributary drainages. Sites within the study area meeting those criteria $(n=41)$ were mapped on U.S. Geological Survey 7.5-minute topographic maps and listed as sites to relocate during the course of the project (these sites are listed in Table 6 and also are indicated by an asterisk in the complete study area inventory presented in Appendix A, Table A.1). Because previously unrecorded sites also were likely to occur in these areas, the areas meeting those criteria, but lacking recorded sites, were also marked on the topographic maps to be investigated.

Few sites occurred in canyon areas, other than the high bedrock terraces that were unlikely to be impacted by the river. The canyon bottoms were either unsuitable for site location and/or were scoured frequently by high-water events prior to dam construction. Also, the possibility of impacts occurring as a result of hydropower operations below the confluence of the Green and Yampa Rivers was unclear. Consequently, only the noncanyon areas of Little Hole and Browns Park were chosen for the field study.

\subsubsection{Site Characterization}

Once a potentially affected area was defined, all relevant files, reports, maps, and site forms were assembled. The reports of previous studies provided some information for characterizing the types of sites located within that area. The MESA Corporation Peaking Power Project report by Norman and Merrill (1981) was particularly important because it was a low-intensity sampling survey of the entire study area. The $30 \%$ of the area that received a high-intensity (100\%) survey was primarily bottomlands in Browns Park; however, most of the surveyed area did not extend to the riverbank. The prehistoric sites recorded in the previous surveys ranged from small surficial lithic scatters to habitation sites, and the historic sites ranged from trash scatters to abandoned homesteads. The reports of previous surveys also provided information on prior disturbance and impacts at some sites (e.g., water erosion, vandalism).

\subsubsection{Data Collection}

To measure the potential for impacts, previously recorded sites were relocated using the topographic maps and site forms. A data form was designed to record information 
TABLE 6 Sites Evaluated within the Potentially Affected Area

\begin{tabular}{|c|c|c|c|c|c|c|}
\hline Site I.D. ${ }^{\mathrm{a}}$ & Period & Site Type & Structures & Features & $\begin{array}{l}\text { Land } \\
\text { Status }^{b}\end{array}$ & $\begin{array}{c}\text { National Register } \\
\text { Status }\end{array}$ \\
\hline \multicolumn{7}{|l|}{ Little Hole } \\
\hline $42 \mathrm{DA} 40$ & Prehistoric & Campsite & Rock alignment & Lithic scatter & BLM & Undetermined \\
\hline 42DA222 & Prehistoric & Lithic & None & Lithic scatter & USFS & $\begin{array}{l}\text { Potentially not } \\
\text { eligible }\end{array}$ \\
\hline 42DA223 & Prehistoric & Lithic & None & Lithic scatter & USFS & $\begin{array}{l}\text { Potentially not } \\
\text { eligible }\end{array}$ \\
\hline 42DA224 & Prehistoric & Lithic & None & Lithic scatter & USFS & $\begin{array}{l}\text { Potentially not } \\
\text { eligible }\end{array}$ \\
\hline 42DA227 & Historic & $\begin{array}{l}\text { Placer mining } \\
\text { operation }\end{array}$ & $\begin{array}{l}\text { Canal; several } \\
\text { structures; retaining } \\
\text { walls }\end{array}$ & Trash scatter & BLM & Potentially eligible \\
\hline 42DA275 & Prehistoric & Lithic & None & Lithic scatter & BLM & $\begin{array}{l}\text { Potentially not } \\
\text { eligible }\end{array}$ \\
\hline 42DA332 & $\begin{array}{l}\text { Prehistoric and } \\
\text { Historic }\end{array}$ & $\begin{array}{l}\text { Prehistoric lithic } \\
\text { scatter; historic } \\
\text { corral }\end{array}$ & None & Lithic scatter & BLM & Potentially eligible \\
\hline 42DA333 & Late $1800 \mathrm{~s}$ & $\begin{array}{l}\text { Wagon road and } \\
\text { fence remnant }\end{array}$ & Fence & Wagon road & USFS & Potentially eligible \\
\hline 42DA334 & Prehistoric & Lithic & None & Lithic scatter; mano & USFS & $\begin{array}{l}\text { Potentially not } \\
\text { eligible }\end{array}$ \\
\hline 42DA335 & Prehistoric & Campsite & None & Lithic scatter & BLM & Not eligible \\
\hline
\end{tabular}


TABLE 6 (Cont.)

\begin{tabular}{|c|c|c|c|c|c|c|}
\hline Site I.D. ${ }^{\mathrm{a}}$ & Period & Site Type & Structures & Features & $\begin{array}{l}\text { Land } \\
\text { Status }^{\mathrm{b}}\end{array}$ & $\begin{array}{c}\text { National Register } \\
\text { Status }\end{array}$ \\
\hline \multicolumn{7}{|c|}{ Upper Browns Park } \\
\hline 42DA196 & Prehistoric & Lithic & None & Lithic scatter & BLM & Undetermined \\
\hline 42DA202 & Prehistoric & Lithic & None & Lithic scatter; hearth & BLM & Undetermined \\
\hline 42DA203 & Post Archaic & Campsite & None & Lithic scatter; charcoal & BLM & Undetermined \\
\hline 42DA228 & Prehistoric & Lithic & None & Lithic scatter & BLM & Undetermined \\
\hline 42DA241/339 & Prehistoric & Lithic & None & Lithic scatter & BLM & Undetermined \\
\hline 42DA336 & $\begin{array}{l}\text { Prehistoric and } \\
\text { Historic }\end{array}$ & $\begin{array}{l}\text { Rockshelter; } \\
\text { historic hearth }\end{array}$ & None & Lithic scatter; hearth & BLM & Potentially eligible \\
\hline 42DA337 & $\begin{array}{l}\text { Historic; } \\
\text { Pre-1900 }\end{array}$ & Saloon & Rock foundations & Trash scatter & BLM & Potentially eligible \\
\hline 42DA338 & $\begin{array}{l}\text { Historic; } \\
\text { Euro-American }\end{array}$ & Irrigation canal & $\begin{array}{l}\text { Flume support for } \\
\text { irrigation }\end{array}$ & Wagon box & BLM & Potentially eligible \\
\hline 42DA342 & $\begin{array}{l}\text { Historic; } \\
\text { Euro-American }\end{array}$ & $\begin{array}{l}\text { Bridge and } \\
\text { dugouts }\end{array}$ & Bridge & Dugouts; ceramic; glass & BLM & Potentially eligible \\
\hline 42DA394 & Historic & Irrigation ditch & None & None & BLM & Undetermined \\
\hline 42DA485 & Prehistoric & $\begin{array}{l}\text { Campsite; lithic } \\
\text { workshop }\end{array}$ & None & $\begin{array}{l}\text { Hearth; charcoal; lithic } \\
\text { scatter }\end{array}$ & BLM & Potentially eligible \\
\hline $\begin{array}{l}\text { John Jarvie } \\
\text { Ranch }\end{array}$ & $\begin{array}{l}\text { Late } 19 \text { th, early } \\
20 \text { th century }\end{array}$ & Settlement & Several structures & $\begin{array}{l}4 \text { graves; ferry; } \\
\text { irrigation ditches }\end{array}$ & BLM & Listed \\
\hline
\end{tabular}


TABLE 6 (Cont.)

\begin{tabular}{|c|c|c|c|c|c|c|}
\hline Site I.D. ${ }^{\mathrm{a}}$ & Period & Site Type & Structures & Features & $\begin{array}{l}\text { Land } \\
\text { Status }^{b}\end{array}$ & $\begin{array}{c}\text { National Register } \\
\text { Status }\end{array}$ \\
\hline \multicolumn{7}{|c|}{ Lower Browns Park } \\
\hline 5MF605 & 19 th century & Fur trading post & None & Not specified & USFWS & Listed \\
\hline 5MF688 & Fremont & Petroglyph panel & None & $\begin{array}{l}\text { Bedrock mortar; } \\
\text { metate; petroglyphs }\end{array}$ & USFWS & Eligible \\
\hline 5MF840 & Protohistoric & Campsite & None & $\begin{array}{l}\text { Lithic scatter; tepee } \\
\text { rings; hearths }\end{array}$ & USFWS & Potentially eligible \\
\hline 5MF841 & Protohistoric & Lithic workshop & None & $\begin{array}{l}\text { Lithic scatter; manos } \\
\text { and metates }\end{array}$ & USFWS & Potentially eligible \\
\hline $5 \mathrm{MF} 859$ & Historic & Round corral & Corral & Logs & USFWS & Undetermined \\
\hline $5 \mathrm{MF} 1229$ & Historic & Campsite & None & Trash scatter & USFWS & Not eligible \\
\hline $5 \mathrm{MF} 1230$ & Prehistoric & Lithic & None & Lithic scatter & USFWS & Undetermined \\
\hline $5 \mathrm{MF} 1231$ & 19 th century & Log cabin & Cabin & Irrigation canal & USFWS & Eligible \\
\hline $5 \mathrm{MF} 1232$ & 19th century & Log cabin & Cabin & Not specified & USFWS & Eligible \\
\hline $5 \mathrm{MF} 1233$ & 19th century & Trash dump & None & Trash dump & USFWS & Potentially eligible \\
\hline 5MF1234 & Historic & Architectural & $\begin{array}{l}\text { Animal shed and cable } \\
\text { ferry structure }\end{array}$ & Not specified & USFWS & Eligible \\
\hline
\end{tabular}


TABLE 6 (Cont.)

\begin{tabular}{|c|c|c|c|c|c|c|}
\hline Site I.D. ${ }^{\mathrm{a}}$ & Period & Site Type & Structures & Features & $\begin{array}{l}\text { Land } \\
\text { Status }\end{array}$ & $\begin{array}{c}\text { National Register } \\
\text { Status }\end{array}$ \\
\hline \multicolumn{7}{|c|}{ Lower Browns Park (Cont.) } \\
\hline $5 \mathrm{MF} 1235$ & Historic & Ranch & $\begin{array}{l}\text { Log ranchhouse; } \\
\text { outbuildings }\end{array}$ & Not specified & USFWS & Potentially eligible \\
\hline 5MF1236 & ca. 1911 & Log cabin & Stone fireplace & Not specified & USFWS & Potentially eligible \\
\hline 5MF1237 & 19 th century & Log cabin & $\begin{array}{l}2 \text { chimneys; house } \\
\text { foundations }\end{array}$ & Not specified & USFWS & Potentially eligible \\
\hline $5 \mathrm{MF} 1238$ & Prehistoric & Lithic & None & Lithic scatter & USFWS & Not eligible \\
\hline \multicolumn{7}{|c|}{ Dinosaur National Monument } \\
\hline $5 \mathrm{MF} 62$ & Prehistoric & Lithic & None & Lithic scatter; manos & NPS & Undetermined \\
\hline $5 \mathrm{MF} 242$ & Prehistoric & Lithic & None & Lithic scatter & NPS & $\begin{array}{l}\text { Potentially not } \\
\text { eligible }\end{array}$ \\
\hline $5 \mathrm{MF} 2357$ & Historic & $\begin{array}{l}\text { Upper Wade/ } \\
\text { Curtis Cabin }\end{array}$ & Cabin & Concrete foundation & NPS & Listed \\
\hline
\end{tabular}

a Site identification numbers are listed by state number (numbered in alphabetical sequence), county code, and county site number - e.g., $42 \mathrm{DA} 30$ refers to state 42 (Utah), Daggett County (DA), site 30 in the county; the other county code is MF, Moffat County.

b BLM = Bureau of Land Management; NPS = National Park Service; USFS = U.S. Forest Service; USFWS = U.S. Fish and Wildlife Service. 
regarding site location and description, geomorphic setting, sedimentary context, vegetation, slope, distance from the river, elevation above the river level, and site condition; much of this information is not currently available in the reports or on original site forms. These specific variables were considered because of their influence on factors used in determining impacts to the sites. For example, vegetation can be correlated with erodability because a sparsely vegetated slope would be more susceptible to erosion than a densely vegetated slope. Geomorphic setting and sedimentary context indicate whether the surface on which the site is located is capable of being eroded or scoured. Slope, elevation and distance to water provide information on whether the site is at risk for cutbank erosion, sheetwash erosion, or flooding. The site condition also provides information regarding previous erosion events or vandalism that might be associated with hydropower operations.

Each site was designated as having a high or low potential for erosion on the basis of its setting and condition. These designations were subsequently used in concert with the hydrologic projections of the hydropower operational scenarios under consideration in the EIS to arrive at specific impact assessments.

Previously unrecorded sites were also encountered. These sites are listed in Appendix A, Table A.2. The completed data forms for the previously recorded sites and for the new sites (previously unrecorded) are reproduced in Appendix B. 


\section{DISTRIBUTION OF ARCHAEOLOGICAL REMAINS AND GEOMORPHOLOGY}

The distribution of archaeological remains below Flaming Gorge Dam is related to the major geomorphic features present within the study area - that is, the bedrock canyons and outcrops, riverine terraces, tributary alluvium, side-valley fans, and aeolian deposits. The locations of prehistoric and historic sites at Little Hole, Upper Browns Park, and Lower Browns Part in relation to these features are shown in Figure 8.

The canyon areas below Flaming Gorge Dam (Red Canyon, Swallow Canyon, and Canyon of Lodore) were not investigated during this field study because the canyon bottoms have a low potential for containing archaeological remains, as demonstrated in the MESA Corporation survey (Norman and Merrill 1981). Few areas within the canyon are suitable for site location other than the high bedrock terraces and benches, and the bottoms were scoured frequently during high-water events before Flaming Gorge Dam was constructed. A similar pattern is evident along the Gunnison River, which represents another major Upper Colorado River tributary (Buckles 1964; Breternitz 1974). The bedrock exposed in the canyons is almost exclusively confined to Precambrian sandstone and quartzite (Uinta Mountain Group), which also crops out in various locations along the river corridor (Hansen 1965:15-38). Several archaeological sites occupy bedrock surfaces and would not be subject to riverine erosion in the foreseeable future.

The lowest Quaternary bench gravels are less than $20 \mathrm{ft}$ above the water level and comprise gravels and cobbles interbedded with sand and silt (Hansen 1965:131-132). These deposits are assigned to the Pleistocene and may date to the Wisconsin Glaciation (Hansen 1965:131). In Little Hole, the lowest bench gravel (mapped as $\mathrm{Qb}_{4}$ ) is about $18 \mathrm{ft}$ above the river, and it is interrupted in places by large bedrock formations on both banks. All of the sites in Little Hole, prehistoric and historic, are located on this terrace, higher bench gravels $\left(\mathrm{Qb}_{3}\right.$ and $\left.\mathrm{Qb}_{2}\right)$, or bedrock. The older bench gravels are thought to antedate the Wisconsin Glaciation (Hansen 1965:131).

The lowest terrace, which is composed of sand and ranges between $6 \mathrm{ft}$ and $9 \mathrm{ft}$ above the floodplain, is present in Little Hole and Browns Park. The modern soil profile on this terrace in Lower Browns Park appears to be no more than 150 years old (Eddy et al. 1982:12), indicating a late Holocene age. In Little Hole, no sites were recorded on this terrace (about $6 \mathrm{ft}$ ) during previous surveys (Moeller et al. 1993), and no sites were encountered during this field study.

In Upper Browns Park, the low sandy terrace (about $6 \mathrm{ft}$ ) is present between Red Canyon and Jarvie Ranch; however, it is absent downstream of Jarvie Ranch, where the river turns sharply to the south. The low terrace reappears briefly upstream of Swallow Canyon. One historic site is recorded on the low terrace in Upper Browns Park. Lower Browns Park (i.e., below Swallow Canyon) is characterized by extensive bottomlands and wetland areas. 


\section{Prehistoric and \\ Historic Sites}

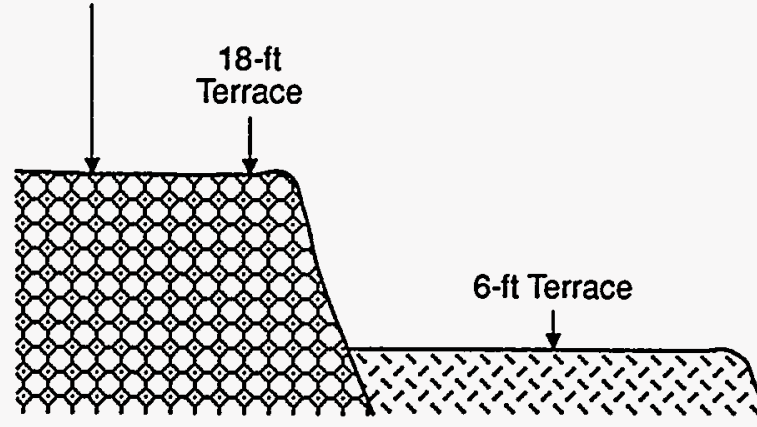

Floodplain

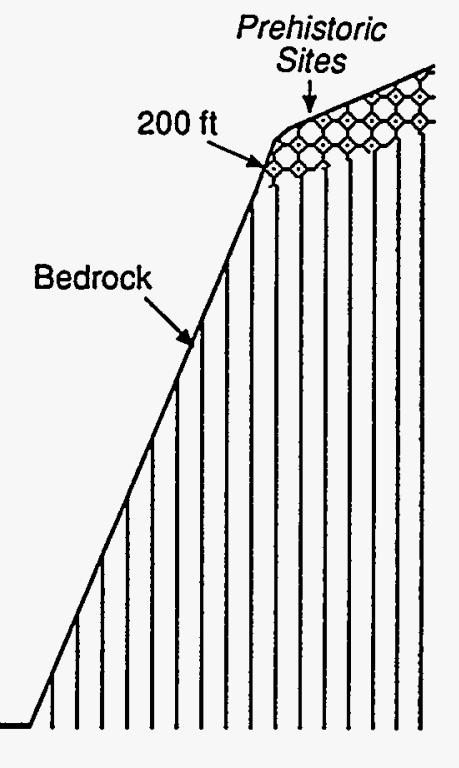

Upper Browns Park

\section{Prehistoric}

Sites 60-ft Terrace

tot

Bedrock

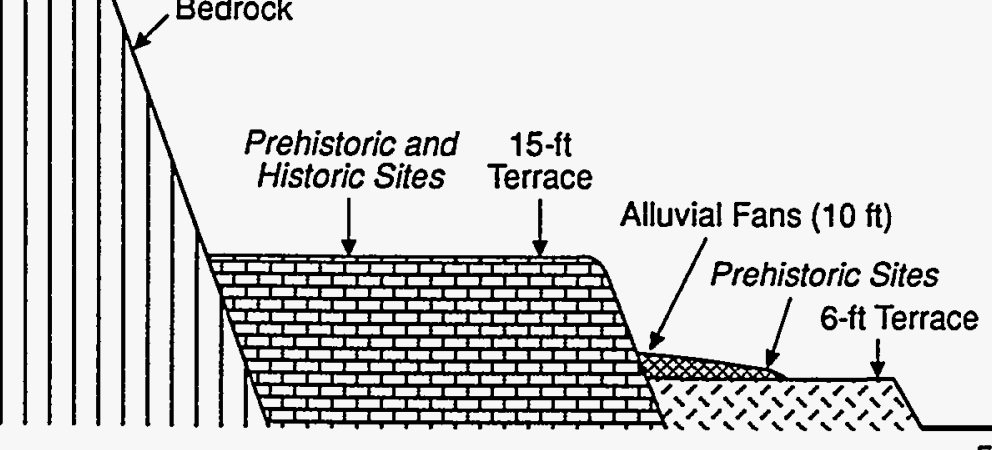

Floodplain

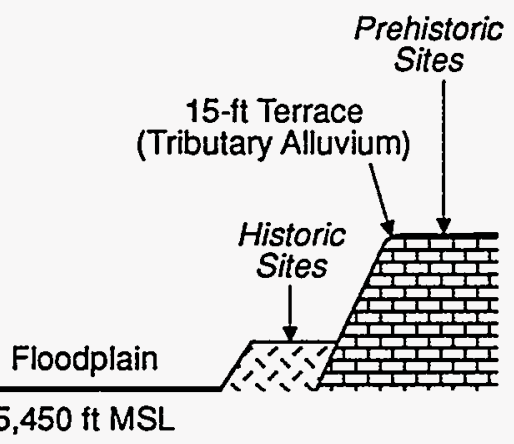

$5,450 \mathrm{ft}$ MSL

\section{Lower Browns Park}

\section{Prehistoric}

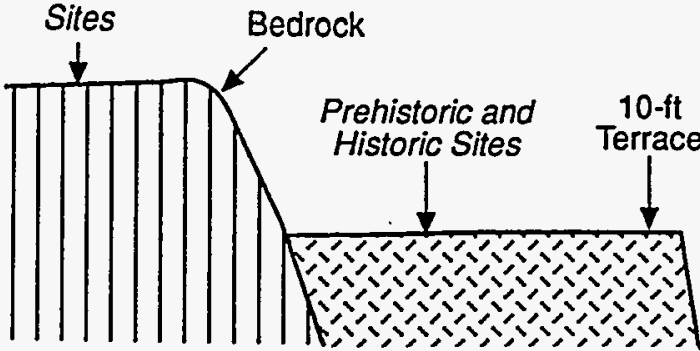

$10-\mathrm{ft}$

Terrace 
The lowest terrace, which is about $9 \mathrm{ft}$ above the river (and may or may not represent the same terrace identified above), is broadly developed along this portion of the river. Several sites are located on this terrace, both historic and prehistoric, and on either side of the river.

Alluvial fans have accumulated at the mouths of many tributary streams along the Green River. At the uppermost end of Browns Park, near the entrance to Red Canyon, fans apparently accumulated on the lowest terrace level at the time that this level represented the active floodplain. Thus, these fans should post-date deposition of the sediment that comprises the lowest terrace (i.e., they are probably of late Holocene age). The surfaces of these features are about 10 to $15 \mathrm{ft}$ above the river. Two new sites were encountered on these fans; both sites are lithic scatters with the potential to contain subsurface materials. Several sites in Upper Browns Park are located on deposits mapped as tributary alluvium (primarily sand and silt); these deposits accumulated along side-valley streams and in the main valley and are also of Holocene age (Hansen 1965:133).

Sites also occupy areas covered with aeolian sediment (also of Holocene age) derived from the floodplain, tributary alluvium, and older deposits (including bench gravels) (Hansen 1965:137). Aeolian sand forms active and stabilized dunes on various terrace levels, and thus overlies alluvial deposits of Pleistocene and Holocene age (e.g., bench gravels and tributary alluvium). 


\section{ANALYSIS OF IMPACTS TO ARCHAEOLOGICAL REMAINS}

The potential for impacts to archaeological sites is rated high or low on the basis of (1) sediment loads and stage changes projected for the hydropower operational scenarios, (2) site locations and information recorded on site data forms and in photographs, (3) amount of and potential for erosion, and (4) integrity and potential National Register eligibility of the sites. Eight sites were rated as having a high potential for impact due to erosion; two of these sites have been mitigated. Thirty-one sites have low or no potential for impact. The potential for impact to the remaining eight sites is undetermined at this time. The sites considered to have a high potential for impact are listed in Table 7.

\subsection{HYDROLOGICAL FACTORS}

The critical hydrological factors related to impacts to cultural resources downstream of Flaming Gorge Dam are sediment load (the amount of sediment in the river system) and stage change (the amount of fluctuation measured by the change in river depth) and their relationship to the amount and rate of erosion. Sediment load and stage change vary, depending on the particular hydropower operational scenario. The hydropower operational scenarios considered for Flaming Gorge Dam are year-round high fluctuating flows, seasonally adjusted high fluctuating flows, seasonally adjusted moderate fluctuating flows, and seasonally adjusted steady flows. These scenarios are described and evaluated in Yin et al. (1995) and Williams et al. (1995).

The year-round high fluctuating flow scenario is based on historical dam releases and current operating constraints, that is, prior to the Biological Opinion of the U.S. Fish and Wildlife Service (1992). The seasonally adjusted high fluctuating flow scenario would operate within the Biological Opinion but at the maximum fluctuation allowed. The seasonally adjusted moderate fluctuating flow and steady flow scenarios would operate at $50 \%$ fluctuation and no fluctuation (constant flow), respectively. The seasonally adjusted steady flow scenario is considered to be a "no effect" scenario for hydropower operations because dam releases would not be controlled by Western for hydropower production.

An estimated 170,000 to more than 3,500,000 tons of sediment are flushed downstream of Flaming Gorge Dam each year, depending on whether the year is a normal year, a dry year, or a wet year. The sediment load for each of the hydropower operational scenarios under different hydrologic conditions and the estimated erosion rates are presented in Table 8. The erosion rates would be highest for the high fluctuating flow scenarios and at least $10 \%$ less for the moderate fluctuating flow and steady flow scenarios.

Although the alluvium in Browns Park will eventually erode naturally and the channel will armor, flushing out fine sediment and leaving larger gravels and cobbles, this process will take more than 100 years because of the amount of sediment available. The 
TABLE 7 Archaeological Sites and Historic Structures Downstream of Flaming Gorge Dam that Could Be Affected by Hydropower Operational Scenarios

\begin{tabular}{|c|c|c|c|}
\hline Site I.D. & Site Description & Location & Erosion Potential \\
\hline \multicolumn{4}{|l|}{ Upper Browns Park } \\
\hline Jarvie Ranch & $\begin{array}{l}\text { Historic structure listed } \\
\text { on the National Register; } \\
\text { riprap present }\end{array}$ & $\begin{array}{l}\text { Low sandy terrace; } \\
\text { extends to the river }\end{array}$ & High, but protected \\
\hline 42DA342 & Former historic bridge & $\begin{array}{l}\text { Floodplain and tributary } \\
\text { alluvium on outer } \\
\text { meander of river; } 5 \mathrm{ft} \\
\text { above mean water level; } \\
50 \text { to } 100 \mathrm{ft} \text { from } \\
\text { channel }\end{array}$ & $\begin{array}{l}\text { High, actively eroding, } \\
\text { but may not be eligible } \\
\text { for the National } \\
\text { Register }\end{array}$ \\
\hline 42DA564 & $\begin{array}{l}\text { Prehistoric lithic scatter } \\
\text { with hearths }\end{array}$ & $\begin{array}{l}\text { Tributary alluvium on } \\
\text { vertical bank; } 15 \text { to } 20 \mathrm{ft} \\
\text { above mean water level }\end{array}$ & $\begin{array}{l}\text { Very high; actively } \\
\text { eroding }\end{array}$ \\
\hline \multicolumn{4}{|l|}{ Lower Browns Park } \\
\hline $\begin{array}{l}\text { 5MF605, Fort } \\
\text { Davy Crockett }\end{array}$ & $\begin{array}{l}\text { Historic site; listed on the } \\
\text { National Register; has } \\
\text { been excavated }\end{array}$ & $\begin{array}{l}\text { Low sandy terrace; } \\
\text { extends to cutbank }\end{array}$ & $\begin{array}{l}\text { High, actively eroding } \\
\text { but mitigated }\end{array}$ \\
\hline $5 \mathrm{MF} 840$ & $\begin{array}{l}\text { Protohistoric campsite; } \\
\text { potentially eligible for the } \\
\text { National Register }\end{array}$ & $\begin{array}{l}\text { Low sandy terrace; } \\
100 \mathrm{ft} \text { from channel; } \\
\text { may extend to cutbank } \\
\text { at edge of terrace }\end{array}$ & $\begin{array}{l}\text { High if site extends to } \\
\text { cutbank; more data } \\
\text { needed }\end{array}$ \\
\hline $\begin{array}{l}\text { 5MF1232, James } \\
\text { Warren Cabin }\end{array}$ & $\begin{array}{l}\text { Historic log cabin; poten- } \\
\text { tially eligible for the } \\
\text { National Register }\end{array}$ & $\begin{array}{l}\text { Low sandy terrace; may } \\
\text { extend to edge of terrace }\end{array}$ & $\begin{array}{l}\text { High; more data } \\
\text { needed }\end{array}$ \\
\hline $5 \mathrm{MF} 1234$ & $\begin{array}{l}\text { Historic scatter; poten- } \\
\text { tially eligible for the } \\
\text { National Register }\end{array}$ & $\begin{array}{l}\text { Low sandy terrace; } 10 \mathrm{ft} \\
\text { above mean water level; } \\
\text { extends to cutbank }\end{array}$ & $\begin{array}{l}\text { Very high, actively } \\
\text { eroding }\end{array}$ \\
\hline 5MF3668 & Prehistoric lithic scatter & $\begin{array}{l}\text { Low sandy terrace; } 10 \mathrm{ft} \\
\text { above mean water level; } \\
3 \mathrm{ft} \text { from channel }\end{array}$ & High \\
\hline
\end{tabular}


TABLE 8 Summary of Sand Load in Browns Park

\begin{tabular}{|c|c|c|c|}
\hline \multirow[b]{2}{*}{$\begin{array}{c}\text { Water Year/ } \\
\text { Operational Scenario }\end{array}$} & \multicolumn{3}{|c|}{ Sand Load ${ }^{\mathrm{a}}$ (million tons) } \\
\hline & Value & $\begin{array}{c}\text { Percent } \\
\text { Difference }\end{array}$ & $\begin{array}{l}\text { Erosion } \\
\text { Rate }\end{array}$ \\
\hline \multicolumn{4}{|l|}{ Normal Year (1987) } \\
\hline Year-round high fluctuating flows & 1.15 & 0 & 1.0 \\
\hline Seasonally adjusted high fluctuating flows & 1.10 & -4 & 0.96 \\
\hline Seasonally adjusted moderate fluctuating flows & 0.99 & -14 & 0.86 \\
\hline \multirow[t]{2}{*}{ Seasonally adjusted steady flows } & 0.98 & -15 & 0.85 \\
\hline & \multicolumn{3}{|c|}{ Sand Load ${ }^{\mathrm{a}}$ (million tons) } \\
\hline $\begin{array}{c}\text { Water Year/ } \\
\text { Operational Scenario }\end{array}$ & Value & $\begin{array}{l}\text { Percent } \\
\text { Difference }\end{array}$ & $\begin{array}{c}\text { Erosion } \\
\text { Rate }\end{array}$ \\
\hline \multicolumn{4}{|l|}{ Dry Year (1989) } \\
\hline Year-round high fluctuating flows & 0.17 & 0 & 1.0 \\
\hline Seasonally adjusted high fluctuating flows & 0.29 & 71 & 1.71 \\
\hline Seasonally adjusted moderate fluctuating flows & 0.28 & 65 & 1.65 \\
\hline \multirow[t]{2}{*}{ Seasonally adjusted steady flows } & 0.27 & 59 & 1.59 \\
\hline & \multicolumn{3}{|c|}{ Sand Load ${ }^{\mathrm{a}}$ (million tons) } \\
\hline $\begin{array}{c}\text { Water Year/ } \\
\text { Operational Scenario }\end{array}$ & Value & $\begin{array}{c}\text { Percent } \\
\text { Difference }\end{array}$ & $\begin{array}{c}\text { Erosion } \\
\text { Rate }\end{array}$ \\
\hline \multicolumn{4}{|l|}{ Wet Year (1983) } \\
\hline Year-round high fluctuating flows & 3.57 & 0 & 1.0 \\
\hline Seasonally adjusted high fluctuating flows & 2.60 & -27 & 0.73 \\
\hline Seasonally adjusted moderate fluctuating flows & 2.58 & -28 & 0.72 \\
\hline Seasonally adjusted steady flows & 2.58 & -28 & 0.72 \\
\hline
\end{tabular}

a "Percent Difference" is the percent difference from year-round high fluctuating flows; "Erosion Rate" is the rate of erosion or meandering relative to yearround high fluctuating flows.

Source: Williams et al. (1995). 
armoring process has already begun upstream of Browns Park in Red Canyon and Little Hole. The amount of sediment removed from the banks and the riverbed is proportional to the rate of erosion and meandering. With no sediment input, as is the case when a dam is present, the sediment load is small, so more sediment is removed and more erosion occurs. However, the more sediment that is added to the system, i.e., the larger the sediment load, the less erosive power the river has. Consequently, the potential for erosion is higher in Upper Browns Park than in Lower Browns Park, and the potential for erosion decreases farther downstream toward the Yampa River. At the confluence of the Yampa and Green Rivers, a large amount of sediment is being added to the Green River system by the Yampa, which further reduces the amount of erosion downstream.

Stage change is also important in determining erosion potential because it indicates the volume of water flowing through the system. More erosion is likely to occur when the stage change is large. For all scenarios, the river flow would fluctuate from 800 to $4,700 \mathrm{cfs}$ during the course of one year, and the maximum stage change would be approximately $5 \mathrm{ft}$. The difference among the scenarios is the amount of stage change that would occur on a daily basis. As calculated by Yin et al. (1995), daily stage changes would range from 2.4 to $4.9 \mathrm{ft}$ for the year-round high fluctuating flow scenario at the Gates of Lodore and from 0 to $4.9 \mathrm{ft}$ for the seasonally adjusted high fluctuating flow scenario. However, for the seasonally adjusted moderate fluctuating flow scenario, the daily stage change would be between 0 and $2.1 \mathrm{ft}$. No daily fluctuations would occur under the seasonally adjusted steady flow scenario.

\subsection{POTENTIAL IMPACTS}

\subsubsection{Little Hole}

Most of the sediment within Red Canyon from Flaming Gorge Dam to Browns Park has been removed (the river has been armored); therefore, only minor erosion will occur in this area. No erosion would occur on the 15- to 20-ft terrace in Little Hole and Devils Hole as a result of the hydropower operational scenarios. All known archaeological sites in this area that were investigated during the field study $(n=10)$ are on or above this terrace.

\subsubsection{Upper Browns Park}

Jarvie Ranch. Jarvie Ranch, a National Register site, is on the lowest terrace extending onto the floodplain and has a high potential for impact. However, the site has been mitigated, and steps have been taken to protect the site from erosion, including the construction of a riprap.

Sites 42DA196. Site $42 \mathrm{DA} 196$ is a relocated site in Upper Browns Park on which very little cultural material was found. The site, located on or near a bedrock outcrop and 
sandy beach area just upstream of Little Swallow Canyon, was tested in 1989 during investigations for the Questar north-south pipeline, and surface and buried material were collected. Previously determined ineligible for the National Register, the site has been reevaluated as potentially eligible because it may contain buried cultural deposits (McKibbin 1992). The potential for impact to this site is currently undetermined because the site was not sufficiently relocated on the surface.

Site 42DA202. Site 42DA202 is unlikely to be impacted because it is on the higher terrace, a large distance away from the river, and is not on a meander.

Site 42DA203. Near Tolivers Creek, Site 42DA203 is on the 15- to 20-ft terrace. The site is partially destroyed, and an irrigation ditch separates what remains of the site from the river; therefore, it is unlikely to be affected by changes in hydropower operations.

Site 42DA228. Site 42DA228 was not relocated for reasons of accessibility, and the potential for impact remains undetermined.

Sites 42DA241 (and 42DA339). Another site on the 15- to 20-ft terrace is located between Tolivers Creek and Sears Creek. This site is actually designated as two separate sites, 42DA241 and 42DA339; however, upon observation, the two sites appear to be a continuous lithic scatter. This site has a low potential for impact because it is located on a gentle slope, not a vertical cutbank; it is 150 to $300 \mathrm{ft}$ from the river channel; and it is above the estimated 5 -ft maximum stage change for all scenarios.

Sites 42DA336 and 42DA337. Sites 42DA336 and 42DA337, upstream of Jarvie Ranch, are on the higher 15 - to 20 -ft terrace and are unlikely to be affected by changes to the river resulting from changes in hydropower operations.

Site 42DA338. Site 42DA338, located on the inner bank downstream of Jarvie Ranch, is a more recent irrigation canal than Crouse Ditch. It is unlikely to be affected because the river is more likely to erode the north (outer) bank first.

Site 42DA342. Site $42 D A 342$ is primarily on the 15 - to 20 -ft terrace and would only be affected if the terrace collapsed. However, part of this site is only $5 \mathrm{ft}$ above the water level, which is within the range of stage change for all scenarios. Therefore, this site would be subject to periodic inundation and erosion under all of the hydropower operational scenarios. 
Site 42DA394. Crouse Ditch (Site 42DA394), an irrigation canal eligible for the National Register, follows the entire outer meander of the river downstream of Jarvie Ranch, where the river makes an extremely tight turn to the south. However, parts of the ditch have already been destroyed or modified, whereas others are still in use today. The potential for impact to currently undisturbed portions of the ditch by the hydropower operational scenarios is considered low at this time.

Site 42DA485. Site $42 \mathrm{DA} 485$ is on the 15 - to 20 -ft terrace and is unlikely to be affected by differences in the operational scenarios because of its elevation. Surficial materials were relocated on the site more than $75 \mathrm{ft}$ away from the river. However, archaeological investigations on the Questar pipeline in 1989 revealed subsurface features extending to the east bank of the river (McKibbin 1992). Consequently, there is likely to be a potential for continued impact. The site has been mitigated for pipeline impacts by data recovery, and a no effect determination is likely for hydropower operations.

Sites 42DA561 and 42DA562. Entering Browns Park, two previously unrecorded sites that may contain buried material (42DA561 and 42DA562) are situated on an alluvial fan approximately 10 to $15 \mathrm{ft}$ above the river, between the lowest sandy terrace and the higher 15- to 20 -ft terrace, and 75 to $150 \mathrm{ft}$ away from the bank. Because both sites are above the estimated maximum 5 -ft stage change, the potential for impact is low. In addition, the opposite bank of the river is more likely to erode first.

Site 42DA564. A previously unrecorded site near Tolivers Creek, Site 42DA564 has a high potential for impact. The site is located on the 15 - to 20 -ft terrace but on a vertical bank that is actively eroding; undercutting could cause the bank to collapse. The high fluctuating flow scenarios would affect the site with continuing erosion, whereas the seasonally adjusted moderate and steady fluctuating flow scenarios would decrease the erosion potential only slightly.

\subsubsection{Lower Browns Park}

Site 5MF605. Fort Davy Crockett, Site 5MF605, has already been excavated. The site is located on the $6 \mathrm{ft}$ sandy terrace and would be in danger of continued erosion and potential collapse under high fluctuating flow scenarios. Black plastic, which covered the excavation units, was observed eroding out of the cutbank. The site has been mitigated through data collection.

Site 5MF840. Site 5MF840 is located near Flynn's Bottom, where the stage change is about $4 \mathrm{ft}$. There is a vertical cutbank that appears to be actively eroding. The site is located on a sandy terrace 10 to $15 \mathrm{ft}$ above the water level and may extend to the cutbank. 
Artifacts were located approximately $100 \mathrm{ft}$ from the edge of the terrace. However, the known distribution of cultural material may be a function of vegetation density; visibility was low near the edge. The site is also very large, increasing the likelihood that it may extend closer to the river. If the site does extend to the cutbank, the potential for erosion would be high, especially in the case of high fluctuating flows. A bone was discovered protruding from the cutbank, buried in a dark organic layer, but no cultural material was observed in conjunction with the bone.

Site 5MF841. Site 5MF841 is located on a sandy terrace, approximately $8 \mathrm{ft}$ above the water level. No artifacts or features were discovered on the bank, but some material was found below a bedrock outcrop. If materials are present nearer the river, it is likely that the site could be impacted by high fluctuating flows, but a more precise impact projection cannot be made at this time.

Site 5MF1232. Site 5MF1232 was inaccessible and no data could be collected. However, the site was photographed from the opposite side of the river. The extent of the site is unknown. The site is located on the 6- to 12 -ft sand terrace, and there is a vertical cutbank that is clearly eroding. Similar to the site at Flynn's Bottom (Site 5MF840), if Site 5MF1232 extends to the terrace edge, the potential for erosion would be high for the high fluctuating flow scenarios.

Site 5MF1233. Site 5MF1233, previously identified as a trash scatter, was searched for but not relocated. No projection regarding impacts can be made at this time.

Site 5MF1234. Near the abandoned Wilson Place, historic Site 5MF1234 is subject to ongoing erosion. The site is $10 \mathrm{ft}$ above the water level on the sandy terrace and appears to be actively eroding. Cultural material extends to the cutbank, and several boards were observed on the shoreline. This site is a prime candidate for bank collapse and continued erosion under all hydropower operational scenarios, especially during high fluctuating flows.

Site 5MF1235. The area of Site 5MF1235 was field checked, but no cabin nor remnants of a cabin were located. Potential impacts are, therefore, undetermined.

Sites 5MF1236 and 5MF1237. Sites 5MF1236 and 5MF1237 were not relocated due to accessibility. Therefore, no impact projection can be made.

Site 5MF1238. Site 5MF1238 is located on bedrock and is unlikely to be impacted. 
Site 5MF3668. Site 5MF3668, previously unrecorded, was located downstream of Swallow Canyon in Browns Park National Wildlife Refuge, near Beaver Creek. The site is approximately $10 \mathrm{ft}$ above the water level and is close to the channel. Although the location is not in a particularly exposed area, some removal from the side slope can be expected. The exstimated maximum stage change of $5 \mathrm{ft}$ is likely to impact this site under all scenarios, but the potential for impact is highest under the high fluctuating flow scenarios.

Site 5MF3669. Site 5MF3669, also previously unrecorded, was located at the north entrance of the swinging bridge. It is on the bedrock supporting the bridge and is unlikely to be impacted by the river.

Other Sites. Six other sites relocated in Lower Browns Park (5MF688, 5MF859, and 5MF1228-1231) were found on bedrock outcrops or on higher terraces. It is unlikely that any of these sites would be impacted by the hydropower operational scenarios.

\subsubsection{Dinosaur National Monument}

Sites 5MF242 and 5MF2357. Two sites upstream of the Gates of Lodore within the Dinosaur National Monument boundaries, Sites 5MF242 and 5MF2357, are located on bedrock and would not be affected by the hydropower operational scenarios.

Site 5MF62. Site 5MF62 is recorded along the Green River just above the Yampa River confluence. From the topographic map, it appears to extend to the floodplain. However, the site was not relocated as part of the field study due to problems of accessibility, so it is not possible to evaluate its actual location or its potential for impacts.

Below the Yampa River confluence, enough sediment is being transported into the river system from the Yampa to create a new balance and greatly reduce erosion. Less removal of sediment below the Yampa would create a positive effect because additional sediment would provide increased protection from bank erosion. However, there is no guarantee that aggradation would take place, and, therefore, the positive effect might be diminished to some degree. 


\section{CONCLUSIONS}

The purpose of this field study was to relocate sites along the Green River between Flaming Gorge Dam and the Yampa River confluence and evaluate their potential to be impacted by hydropower operations of the dam. A pilot field study was conducted rather than an intensive survey because of the uncertainty regarding the potential for impacts to occur. On the basis of this pilot study, it was determined that some areas would be affected by higher rates of erosion if Flaming Gorge Dam were operated under the high fluctuating flow scenarios rather than the seasonally adjusted moderate fluctuating or steady flow scenario (Table 9).

TABLE 9 Summary of Impacts to Cultural Resources below Flaming Gorge Dam ${ }^{\text {a }}$

\begin{tabular}{lll}
\hline \multicolumn{1}{c}{ Operational Scenarios } & \multicolumn{1}{c}{ Archaeological Sites } & \multicolumn{1}{c}{ Historic Structures } \\
\hline $\begin{array}{l}\text { Year-round high fluctuating } \\
\text { flows }\end{array}$ & $\begin{array}{l}6 \text { sites potentially impacted } \\
\text { by erosion }\end{array}$ & $\begin{array}{l}\text { 2 structures potentially } \\
\text { impacted by erosion }\end{array}$ \\
$\begin{array}{l}\text { Seasonally adjusted high } \\
\text { fluctuating flows }\end{array}$ & $\begin{array}{l}6 \text { sites potentially impacted } \\
\text { by erosion at a rate of } 4 \% \text { less } \\
\text { than by year-round high fluc- } \\
\text { tuating flows }\end{array}$ & $\begin{array}{l}\text { 2 structures potentially } \\
\text { impacted by erosion at a rate } \\
\text { of } 4 \% \text { less than by year-round } \\
\text { high fluctuating flows }\end{array}$ \\
$\begin{array}{l}\text { Seasonally adjusted moderate } \\
\text { fluctuating flows }\end{array}$ & $\begin{array}{l}\text { 6 sites potentially impacted } \\
\text { by erosion at a rate of 14\% } \\
\text { less than by year-round high } \\
\text { fluctuating flows }\end{array}$ & $\begin{array}{l}\text { 2 structures potentially } \\
\text { impacted by erosion at a rate } \\
\text { of 14\% less than by year- } \\
\text { round high fluctuating flows }\end{array}$ \\
$\begin{array}{l}\text { Seasonally adjusted steady } \\
\text { flows }\end{array}$ & $\begin{array}{l}\text { 6 sites potentially impacted } \\
\text { by erosion at a rate of 15\% } \\
\text { less than by year-round high } \\
\text { fluctuating flows }\end{array}$ & $\begin{array}{l}\text { 2 structures potentially } \\
\text { impacted by erosion at a rate } \\
\text { of 15\% less than by year- } \\
\text { round high fluctuating flows }\end{array}$ \\
\hline
\end{tabular}

a The analysis is based on an erosion rate for a normal water year (Table 8); little difference is noted in the erosion rates for wet and dry years under the seasonally adjusted operational scenarios. The sites and structures that could be affected by the hydropower scenarios are described in Table 7. 


\section{RECOMMENDATIONS}

The following recommendations are based on the findings of the pilot study:

\section{- Little Hole}

- No further investigation or evaluation of sites is necessary in Little Hole because no impacts are projected as a result of changing hydropower operations.

\section{- Upper Browns Park}

- The John Jarvie Ranch site will require consultation with the State Historic Preservation Office on the effectiveness of erosion control efforts in order to obtain a finding of no adverse impact to the site.

- Sites 42DA342 and 42DA564 will require a formal evaluation to determine their eligibility status for the National Register.

- $\quad$ Site 42DA228 should be relocated and assessed for potential impacts.

- No further archaeological survey appears to be necessary in Upper Browns Park because no unsurveyed areas of potential impact were identified.

\section{- Lower Browns Park}

- The amount of lateral erosion that has occurred at Site 5MF605 (Fort Davy Crockett) should be investigated.

- Sites 5MF840, 5MF1232, 5MF1234, and 5MF3668 will require a formal evaluation/determination of National Register eligibility.

- Sites 5MF1233, 5MF1235, 5MF1236, and 5MF1237 should be relocated and assessed for potential impacts associated with changing hydropower operations.

- The following areas should be intensively surveyed for archaeological remains because they might be impacted: river meander at Allen Botton;; river meander at Grimes Bottom; and confluence of Vermillion Creek at the Green River.

- At Dinosaur National Monument, Site 5MF62 at the confluence of the Green and Yampa Rivers should be relocated and any impacts on the site recorded. 


\section{REFERENCES}

Aikens, C.M., 1983, "The Far West," pp. 149-202 in Ancient North Americans, 2nd ed., W.H. Freeman and Company, New York, N.Y.

Aikens, C.M., and D.B. Madsen, 1986, "Prehistory of the Eastern Area," pp. 149-160 in Handbook of North American Indians, Volume 11: Great Basin, W.L. D'Azevedo (editor), Smithsonian Institution, Washington, D.C.

Billat, S.E., 1990, An Archaeological Inventory of One Seismic Line on Goslin Mountain and in Clay Basin in Daggett County, Utah, Brigham Young University Museum of Peoples and Cultures Technical Series No. 90-18, Provo, Utah, Sept. 4.

Breternitz, D.A., 1965, Archaeological Survey in Dinosaur National Monument, ColoradoUtah, 1963-1964, U.S. National Park Service and University of Colorado, Boulder, Colo., May.

Breternitz, D.A., 1970, Archaeological Excavations in Dinosaur National Monument, Colorado-Utah, 1964-1965, University of Colorado Studies, Series in Anthropology No. 17, University of Colorado Press, Boulder, Colo., Aug.

Breternitz, D.A., 1974, Report of Archaeological Reconnaissance, Crystal Dam and Reservoir, Montrose County, Colorado, letter report, Archaeological Research Center, University of Colorado, Mesa Verde National Park, Cortez, Colo., July 5.

Buckles, W. G., 1964, Archaeological Survey of the Morrow Point Dam Area, Montrose and Gunnison Counties, Colorado, report on file, Midwest Archaeological Center, National Park Service, Lincoln, Neb., Nov. 6.

Cook, C.W., 1981, Archaeological Reconnaissance of the Clay Basin Seismic Project, Browns Park, Daggett County, Utah, prepared by Utah Archaeological Research Corporation, Spanish Fork, Utah, for Engineering Specialties Inc. (Federal Permit \#81-UT-181), Conroe, Texas, Aug.

Creasman, S.D., 1985a, PLT Engineering, Inc., Borrow Area, prepared by Western Wyoming College, Rock Springs, Wyo., for PLT Engineering, Inc., Rock Springs, Wyo., May 3.

Creasman, S.D., 1985b, PLT Engineering, Inc., Extra Right-of-Way Width for Chevron's $\mathrm{CO}_{2} / \mathrm{PO}_{4}$ Pipeline Corridors, prepared by Western Wyoming College, Rock Springs, Wyo., for PLT Engineering, Inc., Rock Springs, Wyo., July 1.

Eddy, F.W., et al., 1982, The Archaeological Mitigation Program and Excavations at Site 5MF605, Browns Park National Wildlife Refuge, Moffat County, Colorado, prepared by Science Applications, Inc., Boulder, Colo., for National Park Service, March. 
Fike, R.E., 1976, "Antiquities Site Inventory Forms for Site 42DA56 and 42DA59," Bureau of Land Management, Vernal District, Vernal, Utah, Sept.

Grady, J., 1984, Northwest Colorado Prehistoric Context, State Historical Society of Colorado, Denver, Colo.

Hansen, S., 1980, Browns Park National Wildlife Refuge Survey, Bureau of Land Management, Craig District Office, Craig, Colo., July 11.

Hansen, W.R., 1965, Geology of the Flaming Gorge Area Utah-Colorado-Wyoming, U.S. Geological Survey Professional Paper 490.

Hansen, W.R., 1975, The Geologic Story of the Uinta Mountains, U.S. Government Printing Office, Washington, D.C..

Harper, B., 1978, Cultural Resource Survey of O.D. Ignacio to Sumas Line, Dagget County, Utah, prepared by Department of Anthropology, University of Utah, Salt Lake City, Utah, for Northwest Pipeline Corporation (Antiquities Act Permit 77-UT-081), Salt Lake City, Utah, May.

Iacovetta, B.A., 1977, Archaeological Survey Report: Dutch John Pinon-Juniper Conversion Project, Daggett County, Utah, prepared for U.S. Forest Service, Region Four, Vernal, Flaming Gorge Ranger District, Ashley National Forest, Daggett County, Utah, Sept.

Jennings, J.D., 1978, "Prehistory of Utah and the Eastern Great Basin," University of Utah Anthropological Papers 98.

Jennings, J.D., 1986, "Prehistory: Introduction," pp. 113-119 in Handbook of North American Indians, Volume 11: Great Basin, W.L. D’Azevedo (editor), Smithsonian Institution, Washington, D.C.

Johnson, P.B., no date, "National Register of Historic Places Inventory Site Form for Site 42DA211/AS-160," National Forest Service, Region 4, Dutch John, Utah.

Kouris, D.A., 1988, The Romantic and Notorious History of Browns Park, Wolverine Gallery, Greybull, Wyo.

Leach, L.L., 1970, "Swelter Shelter, 42UN40," pp. 127-135 in Archaeological Excavations in Dinosaur National Monument, Colorado-Utah, 1964-65, University of Colorado Studies/Series in Anthropology No. 17, University of Colorado Press, Boulder, Colo., Aug.

Lindsay, L.W., 1986a, Brown's Park Chaining Archaeological Survey Preliminary Report, Utah Division of State History, Antiquities Section, Salt Lake City, Utah, and U.S. Bureau of Land Management, Vernal District, Vernal, Utah. 
Lindsay, L.W., 1986b, Addendum: Additional Brown's Park Chaining Archaeological Survey Preliminary Report, Utah Division of State History, Antiquities Section, Salt Lake City, Utah, and U.S. Bureau of Land Management, Vernal District, Vernal, Utah.

Madsen, D.B., and K. Sargent, 1979, An Archaeological Inventory of the Brown's Park Land Exchange, Bureau of Land Management, Utah State Office, Salt Lake City, Utah, May 24.

Marwitt, J.P., 1986, "Fremont Cultures," pp. 161-172 in Handbook of North American Indians, Volume 11: Great Basin, W.L. D'Azevedo (editor), Smithsonian Institution, Washington, D.C.

McEnany, T., 1981, Monitoring Report, Spread 5 and 5a, MAPCO Rocky Mountain Liquid Hydrocarbons Pipeline, Report No. 80-22, prepared by Woodward-Clyde Consultants, Walnut Creek, Calif., for University of Utah, Department of Anthropology, Salt Lake City, Utah, March.

McFadden, T., 1978, A Cultural Resource Survey of the Northwest Corporation Pipeline Pinyon-Juniper Pushover, prepared for U.S. National Forest Service, Region Four, Vernal, Flaming Gorge Ranger District, Ashley National Forest, Daggett County, Utah, Nov. 2.

McFadden, T., and A. Worthington, 1978, A Cultural Resource Survey for the Little Hole Campground Expansion and Mann Bench Development, prepared for U.S. National Forest Service, Region Four, Vernal, Flaming Gorge Ranger District, Ashley National Forest, Daggett County, Utah, Aug. 15.

McKibbin, A., 1988, "IMACS Archaeological Site Forms for 42DA485 through 42DA489," recorded by A. McKibbin, Metcalf Archaeological Consultants, Inc., Eagle, Colo., for the Questar North-South Pipeline, Salt Lake City, Utah, Oct. 6.

McKibbin, A. (editor), 1992, The Questar North-South Pipeline: Final Report on Archaeological Investigations, prepared by Metcalf Archaeological Consultants, Inc., Eagle, Colo., for Questar Pipeline Company, Salt Lake City, Utah, July.

Mehls, S.F., 1985, Final Report, Dinosaur National Monument Historic Resources Study, prepared by Western Historical Studies, Inc., Lafayette, Colo., for U.S. National Park Service, Rocky Mountain Regional Office, July 31.

Meyer, J.S., and S.M. Riches, 1979, Cultural Resource Survey, Brown's Park National Wildlife Refuge, prepared by Fort Lewis College, Department of Anthropology, Durango, Colo., for U.S. Fish and Wildlife Service, Browns Park National Wildlife Refuge, Moffat County, Colo., Feb. 8. 
Moeller, K.L., et al., 1993, Class I Overview of Cultural Resources for the Western Area Power Administration Salt Lake City Area Integrated Projects Electric Power Marketing Environmental Impact Statement, ANL/EAD/TM-1, prepared by Argonne National Laboratory, Environmental Assessment Division, Argonne, Ill., for Western Area Power Administration, Nov.

Moore, R.A., 1985, An Archaeological Survey of Three Seismic Lines near Dutch John in Ashley National Forest, Daggett County, Utah, prepared by San Juan County Archaeological Research Center and Library, Division of Conservation Archaeology, for Western Geophysical, Inc., Jan. 7.

Newberry, J.C., 1985, "IMACS Archaeological Site Form for 42DA402," recorded by J.C. Newberry, Archaeological Services, Western Wyoming College, Rock Springs, Wyo., for PLT Engineering, Inc., Rock Springs, Wyo.

Norman, V.G., and D.B. Merrill, 1981, Cultural Resources Survey of the Flaming Gorge Peaking Power Project, MESA CRM Paper No. 4, prepared by MESA Corporation, Orem, Utah, for U.S. Bureau of Reclamation, Upper Colorado Region, Salt Lake City, Utah.

Oprandy, C., 1984, Mann Bench Borrow Site, prepared for U.S. National Forest Service, Region Four, Vernal, Flaming Gorge Ranger District, Ashley National Forest, Daggett County, Utah, Jan.

Tennent, W.L., 1981, "John Jarvie of Browns Park," Cultural Resource Series No. 7, Bureau of Land Management State Office, Salt Lake City, Utah (reprinted July 1982 and Sept. 1984).

Tucker, C.G., 1974, "Antiquities Site Inventory Form for Site 42DA40," Bureau of Land Management, Vernal District, Vernal, Utah, Jan. 11.

Tucker, C.G., 1976, "Antiquities Site Inventory Form for Site 42DA52," Bureau of Land Management, Vernal District, Vernal, Utah, July 21.

Tucker, G.C., 1986, Results of Archaeological Investigations along the Chevron $\mathrm{CO}_{2} \mathrm{PO}_{4}$ Pipelines in Northeastern Utah and Northwestern Colorado, prepared by Nickens and Associates, Montrose, Colo., for Woodward-Clyde Consultants, Walnut Creek, Calif., June.

U.S. Department of Energy, 1996, Salt Lake City Area Integrated Projects Electric Power Marketing Final Environmental Impact Statement, DOE/EIS-0150, Western Area Power Administration, 5 vol.

U.S. Fish and Wildlife Service, 1992, Final Biological Opinion on the Operation of Flaming Gorge Dam, U.S. Fish and Wildlife Service, Mountain-Prairie Region, Denver, Colo., Nov. 25. 
Watts, H.K., 1977, Archaeological Survey Report: Dutch John Pinon-Juniper Conversion Project, Daggett County, Utah, prepared for U.S. Forest Service, Region Four, Vernal, Flaming Gorge Ranger District, Ashley National Forest, Daggett County, Utah, July.

Williams, G.P., et al., 1995, Effects of Flaming Gorge Dam Hydropower Operations on Sediment Transport in the Browns Park Reach of the Green River, Utah and Colorado, ANL/EAD/TM-6, Argonne National Laboratory, Argonne, Inl., May.

Woodward-Clyde Consultants, 1982, Test Excavations: Sixteen Prehistoric Sites along the MAPCO Rocky Mountain Liquid Hydrocarbons Pipeline, Utah and Southwestern Wyoming, Reports of Investigations 80-12, prepared by L.A. Davenport et al., Archaeological Center, Department of Anthropology, University of Utah, Salt Lake City, Utah, Feb.

Woodward-Clyde Consultants, 1983, Cultural Resource Management Program, MAPCO's Rocky Mountain Liquid Hydrocarbons Pipeline, Walnut Creek, Calif., March.

Woodward-Clyde Consultants, 1985, Cultural and Paleontological Resource Inventory Investigations along the Cheuron Carbon Dioxide and Phosphate Slurry Pipeline Corridors, Colorado, Utah, and Wyoming, prepared by Woodward-Clyde Consultants, Walnut Creek, Calif., for Chevron U.S.A. Inc., San Francisco, Calif., Jan. 21.

Yin, S.C.L., et al., 1995, Effects of Flaming Gorge Dam Hydropower Operations on Flow and Stage in the Green River, Utah and Colorado, ANL/EAD/TM-4, Argonne National Laboratory, Argonne, Ill., May. 
APPENDIX A:

RECORDED AND PREVIOUSLY UNRECORDED ARCHAEOLOGICAL SITES FROM FLAMING GORGE DAM TO THE YAMPA RIVER CONFLUENCE 
TABLE A.1 Recorded Archaeological Sites from Flaming Gorge Dam to the Yampa River Confluence

\begin{tabular}{|c|c|c|c|c|c|c|}
\hline Site I.D. ${ }^{a, b}$ & Period & Site Type & Structures & Features & Disturbance & $\begin{array}{c}\text { National Register } \\
\text { Status }\end{array}$ \\
\hline 42DA30 & Late Prehistoric & Architectural & Stone slab structure & Clay roof & Not specified & Undetermined \\
\hline $42 \mathrm{DA} 40^{*}$ & Prehistoric & Campsite & Rock alignment & Lithic scatter & Water erosion & Undetermined \\
\hline 42DA52 & Prehistoric & Campsite & None & $\begin{array}{l}6 \text { firepits; lithic } \\
\text { scatter }\end{array}$ & Vandalism & Potentially eligible \\
\hline 42DA53 & Prehistoric & Campsite & None & $\begin{array}{l}\text { Hearths, middens, } \\
\text { fire-cracked rock }\end{array}$ & Not specified & Potentially eligible \\
\hline 42DA56 & Prehistoric & Campsite & None & $\begin{array}{l}\text { Lithic scatter; } \\
\text { hearth }\end{array}$ & Not specified & $\begin{array}{l}\text { Potentially not } \\
\text { eligible }\end{array}$ \\
\hline 42DA59 & Prehistoric & Lithic & None & Lithic scatter & Not specified & Undetermined \\
\hline 42DA61 & Prehistoric & Campsite & None & Hearths & Not specified & Eligible \\
\hline 42DA69 & Prehistoric & Lithic workshop & None & Lithic scatter & Not specified & Potentially eligible \\
\hline 42DA166; AS112 & Prehistoric & Lithic & None & Lithic scatter & Not specified & Undetermined \\
\hline 42DA167; AS113 & Historic & Habitation & Two log cabins & 4 concrete blocks & Looting & Potentially eligible \\
\hline 42DA168; AS114 & Prehistoric & Lithic & None & $\begin{array}{l}\text { Lithic scatter; } \\
1 \text { Uinta Grey } \\
\text { Fremont sherd }\end{array}$ & Not specified & Undetermined \\
\hline 42DA174; AS124 & Prehistoric & Lithic & None & Lithic scatter & Not specified & Undetermined \\
\hline 42DA175; AS125 & Prehistoric & Lithic & None & Lithic scatter & Not specified & Undetermined \\
\hline 42DA176 & Prehistoric & Lithic & None & Lithic scatter & Not specified & Not eligible \\
\hline
\end{tabular}


TABLE A.1 (Cont.)

\begin{tabular}{|c|c|c|c|c|c|c|}
\hline Site I.D. ${ }^{a, b}$ & Period & Site Type & Structures & Features & Disturbance & $\begin{array}{c}\text { National Register } \\
\text { Status }\end{array}$ \\
\hline 42DA196* AS141 & Prehistoric & Lithic & None & Lithic scatter & $\begin{array}{l}\text { Erosion; inundation; } \\
\text { cattle; jeep trail; } \\
\text { looting }\end{array}$ & Undetermined \\
\hline $42 \mathrm{DA} 202^{*}$ & Prehistoric & Lithic & None & $\begin{array}{l}\text { Lithic scatter; } \\
\text { hearth }\end{array}$ & Surface disturbance & Undetermined \\
\hline $42 \mathrm{DA} 203^{*}$ & Post Archaic & Campsite & None & $\begin{array}{l}\text { Lithic scatter; } \\
\text { charcoal }\end{array}$ & Fence & Undetermined \\
\hline 42DA204 & Prehistoric & Lithic & None & Lithic scatter & Not specified & $\begin{array}{l}\text { Potentially not } \\
\text { eligible }\end{array}$ \\
\hline 42DA211 & Historic & Dugout cabin & Cabin; cellar & None & Not specified & Potentially eligible \\
\hline 42DA214 & Prehistoric & Lithic & None & Lithic scatter & Not specified & $\begin{array}{l}\text { Potentially not } \\
\text { eligible }\end{array}$ \\
\hline $\begin{array}{l}\text { 42DA222; } \\
\text { BLM } 199\end{array}$ & Prehistoric & Lithic & None & Lithic scatter & Not specified & $\begin{array}{l}\text { Potentially not } \\
\text { eligible }\end{array}$ \\
\hline $\begin{array}{l}\text { 42DA223*; } \\
\text { BLM200; AS301 }\end{array}$ & Prehistoric & Lithic & None & Lithic scatter & Not specified & $\begin{array}{l}\text { Potentially not } \\
\text { eligible }\end{array}$ \\
\hline $\begin{array}{l}\text { 42DA224*; } \\
\text { BLM201; AS302 }\end{array}$ & Prehistoric & Lithic & None & Lithic scatter & Not specified & $\begin{array}{l}\text { Potentially not } \\
\text { eligible }\end{array}$ \\
\hline $\begin{array}{l}\text { 42DA226; } \\
\text { BLM203 }\end{array}$ & Prehistoric & $\begin{array}{l}\text { Campsite; } \\
\text { rockshelter }\end{array}$ & None & Lithic scatter & Not specified & Undetermined \\
\hline $\begin{array}{l}\text { 42DA227*; } \\
\text { BLM205 }\end{array}$ & Historic & $\begin{array}{l}\text { Placer mining } \\
\text { operation }\end{array}$ & $\begin{array}{l}\text { Canal; several } \\
\text { structures; retaining } \\
\text { walls }\end{array}$ & Trash scatter & Not specified & Potentially eligible \\
\hline
\end{tabular}




\section{TABLE A.1 (Cont.)}

\begin{tabular}{|c|c|c|c|c|c|c|}
\hline Site I.D. ${ }^{a, b}$ & Period & Site Type & Structures & Features & Disturbance & $\begin{array}{c}\text { National Register } \\
\text { Status }\end{array}$ \\
\hline $\begin{array}{l}\text { 42DA228*; } \\
\text { BLM216 }\end{array}$ & Prehistoric & Lithic & None & Lithic scatter & Not specified & Undetermined \\
\hline $\begin{array}{l}\text { 42DA241; } \\
\text { BLM219 }\end{array}$ & Prehistoric & Lithic & None & Lithic scatter & Not specified & Undetermined \\
\hline $\begin{array}{l}\text { 42DA275*; } \\
\text { BLM202 }\end{array}$ & Prehistoric & Lithic & None & Lithic scatter & Not specified & $\begin{array}{l}\text { Potentially not } \\
\text { eligible }\end{array}$ \\
\hline $\begin{array}{l}\text { 42DA332*; } \\
\text { BLM206 }\end{array}$ & $\begin{array}{l}\text { Prehistoric and } \\
\text { Historic }\end{array}$ & $\begin{array}{l}\text { Prehistoric lithic } \\
\text { scatter; historic } \\
\text { corral }\end{array}$ & None & Lithic scatter & Not specified & Potentially eligible \\
\hline $\begin{array}{l}\text { 42DA333*; } \\
\text { BLM207; AS303 }\end{array}$ & Late $1800 \mathrm{~s}$ & $\begin{array}{l}\text { Wagon road and } \\
\text { fence remnant }\end{array}$ & Fence & Wagon road & Not specified & Potentially eligible \\
\hline $\begin{array}{l}\text { 42DA334*; } \\
\text { BLM208; AS304 }\end{array}$ & Prehistoric & Lithic & None & Lithic scatter; mano & Not specified & $\begin{array}{l}\text { Potentially not } \\
\text { eligible }\end{array}$ \\
\hline $\begin{array}{l}\text { 42DA335*; } \\
\text { BLM209 }\end{array}$ & Prehistoric & Campsite & None & Lithic scatter & Not specified & Not eligible \\
\hline $\begin{array}{l}\text { 42DA336; } \\
\text { BLM210 }\end{array}$ & $\begin{array}{l}\text { Prehistoric and } \\
\text { Historic }\end{array}$ & $\begin{array}{l}\text { Rockshelter; } \\
\text { historic hearth }\end{array}$ & None & $\begin{array}{l}\text { Lithic scatter; } \\
\text { hearth }\end{array}$ & Not specified & Potentially eligible \\
\hline $\begin{array}{l}\text { 42DA337*; } \\
\text { BLM211 }\end{array}$ & Pre-1900 & Saloon & Rock foundations & Trash scatter & Not specified & Potentially eligible \\
\hline $\begin{array}{l}\text { 42DA338*; } \\
\text { BLM213 }\end{array}$ & Euro-American & Irrigation canal & $\begin{array}{l}\text { Flume support for } \\
\text { irrigation }\end{array}$ & Wagon box & Not specified & Potentially eligible \\
\hline 42DA339* & Prehistoric & Lithic & None & Lithic scatter & Not specified & Not eligible \\
\hline $42 \mathrm{DA} 342^{*}$ & Euro-American & $\begin{array}{l}\text { Bridge and } \\
\text { dugouts }\end{array}$ & Bridge & $\begin{array}{l}\text { Dugouts; ceramic; } \\
\text { glass }\end{array}$ & Not specified & Potentially eligible \\
\hline
\end{tabular}


TABLE A.1 (Cont.)

\begin{tabular}{|c|c|c|c|c|c|c|}
\hline Site I.D. ${ }^{a, b}$ & Period & Site Type & Structures & Features & Disturbance & $\begin{array}{c}\text { National Register } \\
\text { Status }\end{array}$ \\
\hline 42DA387 & Prehistoric & Lithic & None & Lithic scatter & Not specified & Potentially eligible \\
\hline 42DA388 & Prehistoric & Lithic & None & $\begin{array}{l}\text { Lithic scatter; } \\
\text { midden }\end{array}$ & Not specified & Potentially eligible \\
\hline 42DA393 & Prehistoric & Campsite & None & $\begin{array}{l}\text { Lithic scatter; } \\
\text { charcoal deposits }\end{array}$ & Not specified & Eligible \\
\hline $42 \mathrm{DA} 394^{*}$ & Historic & Irrigation ditch & None & None & Not specified & Undetermined \\
\hline 42DA395 & Historic & Stagecoach route & None & None & Not specified & Potentially eligible \\
\hline 42DA402 & Prehistoric & Campsite & None & $\begin{array}{l}\text { Lithic scatter; } \\
\text { groundstone; } \\
\text { possible subsurface }\end{array}$ & Not specified & Potentially eligible \\
\hline 42DA406 & Prehistoric & Campsite & None & Hearth & Not specified & Potentially eligible \\
\hline 42DA407 & Prehistoric & Rock alignment & $\begin{array}{l}\text { Rectangular rock } \\
\text { alignment }\end{array}$ & None & Not specified & Potentially eligible \\
\hline 42DA408 & Archaic & Campsite & None & None & Not specified & Potentially eligible \\
\hline 42DA409 & Archaic & Campsite & None & Hearths & Not specified & Potentially eligible \\
\hline 42DA410 & Prehistoric & Lithic & None & Lithic scatter & Not specified & $\begin{array}{l}\text { Potentially not } \\
\text { eligible }\end{array}$ \\
\hline 42DA411 & Prehistoric & Lithic quarry & None & Lithic scatter & Not specified & $\begin{array}{l}\text { Potentially not } \\
\text { eligible }\end{array}$ \\
\hline
\end{tabular}


TABLE A.1 (Cont.)

\begin{tabular}{|c|c|c|c|c|c|c|}
\hline Site I.D. ${ }^{\mathrm{a}, \mathrm{b}}$ & Period & Site Type & Structures & Features & Disturbance & $\begin{array}{c}\text { National Register } \\
\text { Status }\end{array}$ \\
\hline 42DA412 & Prehistoric & Campsite & None & $\begin{array}{l}\text { Hearth; midden } \\
\text { areas }\end{array}$ & Not specified & Potentially eligible \\
\hline 42DA413 & Prehistoric & Lithic & None & Lithic scatter & Not specified & $\begin{array}{l}\text { Potentially not } \\
\text { eligible }\end{array}$ \\
\hline 42DA414 & Prehistoric & Campsite & None & $\begin{array}{l}\text { Several possible } \\
\text { hearths }\end{array}$ & Not specified & Potentially eligible \\
\hline $42 \mathrm{DA} 415$ & Prehistoric & Campsite & None & $\begin{array}{l}\text { Hearth; fire-cracked } \\
\text { rock }\end{array}$ & Not specified & Potentially eligible \\
\hline 42DA416 & Prehistoric & Rockshelter & None & Midden area & Not specified & Potentially eligible \\
\hline $42 \mathrm{DA} 417$ & Prehistoric & Campsite & None & At least 4 hearths & Not specified & Potentially eligible \\
\hline 42DA418 & Prehistoric & Campsite & None & None & Not specified & $\begin{array}{l}\text { Potentially not } \\
\text { eligible }\end{array}$ \\
\hline 42DA419 & Prehistoric & Lithic & None & Lithic scatter & Not specified & $\begin{array}{l}\text { Potentially not } \\
\text { eligible }\end{array}$ \\
\hline $42 \mathrm{DA} 420$ & Post Archaic & Campsite & None & $\begin{array}{l}\text { Lithic scatter; } \\
6 \text { hearths }\end{array}$ & Not specified & Potentially eligible \\
\hline 42DA421 & Prehistoric & Lithic quarry & None & Lithic scatter & Not specified & Potentially eligible \\
\hline 42DA422 & Prehistoric & Campsite & None & At least 4 hearths & Not specified & Potentially eligible \\
\hline 42DA423 & Prehistoric & Campsite & None & $\begin{array}{l}\text { Lithic scatter; } \\
11 \text { hearths }\end{array}$ & Not specified & Potentially eligible \\
\hline
\end{tabular}


TABLE A.1 (Cont.)

\begin{tabular}{|c|c|c|c|c|c|c|}
\hline Site I.D. ${ }^{a, b}$ & Period & Site Type & Structures & Features & Disturbance & $\begin{array}{c}\text { National Register } \\
\text { Status }\end{array}$ \\
\hline 42DA424 & Middle Archaic & Campsite & None & $\begin{array}{l}\text { Lithic scatter; } \\
10 \text { hearths }\end{array}$ & Not specified & Potentially eligible \\
\hline 42DA436 & Prehistoric & Campsite & None & $\begin{array}{l}\text { Lithic scatter; slab } \\
\text { hearth }\end{array}$ & Not specified & Potentially eligible \\
\hline 42DA438 & Prehistoric & Campsite & None & $\begin{array}{l}\text { Lithic scatter; } \\
\text { hearths; middens }\end{array}$ & Not specified & Potentially eligible \\
\hline $42 \mathrm{DA} 485^{*}$ & Prehistoric & $\begin{array}{l}\text { Campsite; lithic } \\
\text { workshop }\end{array}$ & None & $\begin{array}{l}\text { Hearth; charcoal; } \\
\text { lithic scatter }\end{array}$ & Not specified & Potentially eligible \\
\hline 42DA486 & Prehistoric & Lithic quarry & None & Lithic scatter & Not specified & $\begin{array}{l}\text { Potentially not } \\
\text { eligible }\end{array}$ \\
\hline 42DA487 & Prehistoric & Lithic & None & Lithic scatter & Not specified & $\begin{array}{l}\text { Potentially not } \\
\text { eligible }\end{array}$ \\
\hline 42DA488 & Fremont & $\begin{array}{l}\text { Lithic and } \\
\text { ceramic scatter }\end{array}$ & None & $\begin{array}{l}\text { Lithic scatter; } \\
\text { ceramic scatter }\end{array}$ & Not specified & Undetermined \\
\hline $42 \mathrm{DA} 489$ & Late Archaic & Lithic & None & Lithic scatter & Not specified & $\begin{array}{l}\text { Potentially not } \\
\text { eligible }\end{array}$ \\
\hline $\begin{array}{l}5 \mathrm{MF} 62^{*} ; \\
\text { Confluence Site }\end{array}$ & Prehistoric & Lithic & None & $\begin{array}{l}\text { Lithic scatter; } \\
\text { manos }\end{array}$ & Not specified & Undetermined \\
\hline $5 \mathrm{MF} 242^{*}$ & Prehistoric & Lithic & None & Lithic scatter & Not specified & $\begin{array}{l}\text { Potentially not } \\
\text { eligible }\end{array}$ \\
\hline $5 \mathrm{MF} 248$ & Prehistoric & Campsite & None & $\begin{array}{l}\text { Lithic scatter; } \\
\text { hearth; ash-charcoal }\end{array}$ & Not specified & Potentially eligible \\
\hline $5 \mathrm{MF} 249$ & Unknown & No data & No data & No data & Not specified & Undetermined \\
\hline
\end{tabular}




\section{TABLE A.1 (Cont.)}

\begin{tabular}{|c|c|c|c|c|c|c|}
\hline Site I.D. ${ }^{\mathrm{a}, \mathrm{b}}$ & Period & Site Type & Structures & Features & Disturbance & $\begin{array}{c}\text { National Register } \\
\text { Status }\end{array}$ \\
\hline $\begin{array}{l}\text { 5MF605*; Fort } \\
\text { Davy Crockett }\end{array}$ & 19th century & Fur trading post & None & Not specified & River erosion & Listed \\
\hline $\begin{array}{l}\text { 5MF688*; Metate } \\
\text { Rock }\end{array}$ & Fremont & Petroglyph panel & None & $\begin{array}{l}\text { Bedrock mortar; } \\
\text { metate; petroglyphs }\end{array}$ & Not specified & Eligible \\
\hline $\begin{array}{l}\text { 5MF840*; Flynn } \\
\text { Bottom }\end{array}$ & Protohistoric & Campsite & None & $\begin{array}{l}\text { Lithic scatter; tepee } \\
\text { rings; hearths }\end{array}$ & None & Potentially eligible \\
\hline $\begin{array}{l}\text { 5MF841*; Carr } \\
\text { Bottom Site }\end{array}$ & Protohistoric & Lithic workshop & None & $\begin{array}{l}\text { Lithic scatter; } \\
\text { manos and metates }\end{array}$ & River erosion & Potentially eligible \\
\hline $5 \mathrm{MF} 842$ & Protohistoric & Campsite & None & $\begin{array}{l}\text { Lithic scatter; } \\
\text { hearths }\end{array}$ & Not specified & Potentially eligible \\
\hline $5 \mathrm{MF} 859^{*}$ & Historic & Round corral & Corral & Logs & Not specified & Undetermined \\
\hline $\begin{array}{l}\text { 5MF1126; Two } \\
\text { Bar Ranch }\end{array}$ & Historic & Livestock ranch & Ranch buildings & No data & Not specified & Eligible \\
\hline $\begin{array}{l}\text { 5MF1127; Lodore } \\
\text { School }\end{array}$ & Historic & $\begin{array}{l}\text { Old Lodore } \\
\text { School }\end{array}$ & $\begin{array}{l}\text { One-room } \\
\text { schoolhouse }\end{array}$ & $\begin{array}{l}\text { Wood frame, front } \\
\text { gable, lumber }\end{array}$ & Not specified & Listed \\
\hline $5 \mathrm{MF} 1228^{*}$ & Prehistoric & Lithic & None & Lithic scatter & Not specified & Undetermined \\
\hline $5 \mathrm{MF} 1229^{*}$ & Historic & Campsite & None & Trash scatter & Moderate & Not eligible \\
\hline $5 \mathrm{MF} 1230^{*}$ & Prehistoric & Lithic & None & Lithic scatter & Moderate & Undetermined \\
\hline $\begin{array}{l}\text { 5MF1231*; Mike } \\
\text { Flynn Cabin }\end{array}$ & 19th century & Log cabin & Cabin & Irrigation canal & Not specified & Eligible \\
\hline $\begin{array}{l}\text { 5MF1232*; James } \\
\text { Warren Cabin }\end{array}$ & 19th century & Log cabin & Cabin & Not specified & Not specified & Eligible \\
\hline
\end{tabular}


TABLE A.1 (Cont.)

\begin{tabular}{|c|c|c|c|c|c|c|}
\hline Site I.D. ${ }^{\mathbf{a}, \mathbf{b}}$ & Period & Site Type & Structures & Features & Disturbance & $\begin{array}{c}\text { National Register } \\
\text { Status }\end{array}$ \\
\hline $5 \mathrm{MF} 1233^{*}$ & 19 th century & Trash dump & None & Trash dump & Not specified & Potentially eligible \\
\hline $5 \mathrm{MF} 1234^{*}$ & Historic & Architectural & $\begin{array}{l}\text { Animal shed } \\
\text { and cable ferry } \\
\text { structure }\end{array}$ & Not specified & Not specified & Eligible \\
\hline $\begin{array}{l}5 \mathrm{MF} 1235^{*} \text {; Larry } \\
\text { Curtin Cabin }\end{array}$ & Historic & Ranch & $\begin{array}{l}\text { Log ranchhouse; } \\
\text { outbuildings }\end{array}$ & Not specified & Not specified & Potentially eligible \\
\hline $5 \mathrm{MF} 1236^{*}$ & ca. 1911 & Log cabin & Stone fireplace & Not specified & Not specified & Potentially eligible \\
\hline $\begin{array}{l}5 \mathrm{MF} 1237^{*} ; \text { Joe } \\
\text { Herrera House }\end{array}$ & 19 th century & Log cabin & $\begin{array}{l}2 \text { chimneys; house } \\
\text { foundations }\end{array}$ & Not specified & Not specified & Potentially eligible \\
\hline $5 \mathrm{MF} 1238^{*}$ & Prehistoric & Lithic & None & Lithic scatter & Road cut & Not eligible \\
\hline $\begin{array}{l}\text { 5MF1398; Carr } \\
\text { Place }\end{array}$ & Historic & $\begin{array}{l}\text { Homestead/ } \\
\text { Ranch }\end{array}$ & No data & No data & Not specified & Potentially eligible \\
\hline $\begin{array}{l}\text { 5MF2357*; Wade/ } \\
\text { Curtis Cabin }\end{array}$ & Historic & $\begin{array}{l}\text { Upper Wade/ } \\
\text { Curtis Cabin }\end{array}$ & Cabin & Concrete foundation & Relocated & Listed \\
\hline 5MF2388 & Historic & $\begin{array}{l}\text { U.S. Geological } \\
\text { Survey camp }\end{array}$ & None & $\begin{array}{l}\text { Tent floors; dugout; } \\
\text { stakes }\end{array}$ & Not specified & Not eligible \\
\hline $\begin{array}{l}\text { 5MF2404; Wade/ } \\
\text { Curtis Cabin }\end{array}$ & Historic & $\begin{array}{l}\text { Lower Wade/ } \\
\text { Curtis Cabin }\end{array}$ & Cabin & Concrete slab & Not specified & Not eligible \\
\hline $5 \mathrm{MF} 2746$ & Prehistoric & Campsite & None & $\begin{array}{l}\text { Lithics; fire-cracked } \\
\text { rock; manos; } \\
\text { metates }\end{array}$ & Not specified & Eligible \\
\hline
\end{tabular}




\section{TABLE A.1 (Cont.)}

\begin{tabular}{|c|c|c|c|c|c|c|}
\hline Site I.D. ${ }^{a, b}$ & Period & Site Type & Structures & Features & Disturbance & $\begin{array}{c}\text { National Register } \\
\text { Status }\end{array}$ \\
\hline $\begin{array}{l}\text { BLM288*; John } \\
\text { Jarvie Ranch }\end{array}$ & $\begin{array}{l}\text { Late } 19 \text { th, early } \\
20 \text { th century }\end{array}$ & Settlement & Several structures & $\begin{array}{l}4 \text { graves; ferry; } \\
\text { irrigation ditches }\end{array}$ & Not specified & Listed \\
\hline $\begin{array}{l}\text { Doc Parson's } \\
\text { Cabin }\end{array}$ & Historic & Cabin & Cabin & None & Not specified & Listed \\
\hline
\end{tabular}

a Site identification numbers are listed by state number (numbered in alphabetical sequence), county code, and county site number - e.g., $42 \mathrm{DA} 30$ refers to state 42 (Utah), Daggett County (DA), site 30 in the county; the other county code is MF, Moffat County. For some sites, an additional or alternative site I.D. is presented: $A S=$ Ashley National Forest; BLM = Bureau of Land Management.

b An asterisk denotes sites located within the potentially affected area (see Section 4.2.1). 
TABLE A.2 Previously Unrecorded Archaeological Sites from Flaming Gorge Dam to the Canyon of Lodore

\begin{tabular}{cllcccc}
\hline Site I.D. & Period & Site Type & Structures & Features & $\begin{array}{c}\text { Land } \\
\text { Status }^{\text {a }}\end{array}$ & $\begin{array}{c}\text { National Register } \\
\text { Status }\end{array}$ \\
\hline 42DA561 & Prehistoric & Lithic & None & Lithic scatter & USFS & Undetermined \\
42DA562 & Prehistoric & Lithic & None & Lithic scatter & BLM & Undetermined \\
42DA563 & $\begin{array}{l}\text { Prehistoric } \\
\text { and Historic }\end{array}$ & $\begin{array}{l}\text { Lithic; historic } \\
\text { trash }\end{array}$ & None & $\begin{array}{l}\text { Lithic scatter; } \\
\text { trash scatter }\end{array}$ & BLM & Undetermined \\
42DA564 & Prehistoric & Lithic & None & Lithic scatter & BLM & Undetermined \\
5MF3668 & Prehistoric & Lithic & None & $\begin{array}{l}\text { Lithic scatter; } \\
\text { possible hearth }\end{array}$ & USFWS & Undetermined \\
5MF3669 & $\begin{array}{l}\text { Prehistoric } \\
\text { and Historic }\end{array}$ & $\begin{array}{l}\text { Lithic; historic } \\
\text { trash }\end{array}$ & None & $\begin{array}{l}\text { Lithic scatter; } \\
\text { trash scatter }\end{array}$ & USFWS & Undetermined \\
\hline
\end{tabular}

a Notation: BLM = Bureau of Land Management; USFS = U.S. Forest Service; USFWS = U.S. Fish and Wildlife Service. 
APPENDIX B:

ARCHAEOLOGICAL SITE IMPACT ANALYSIS DATA FORMS 


\section{ARCHAEOLOGICAL SITE IMPACT ANALYSIS DATA FORM Argonne National Laboratory}

Name: Konnie Moeller/Byron Loosle

Date: $06 / 16 / 92$

Time: $10: 30$

Site No: 42DA40 County/State: Daggett/Utah

USGS Map Reference: Goslin Mountain 7.5 minute Elevation (ft MSL): $5,532 \mathrm{ft}$ at benchmark

Site Reference (report, file): Norman and Merrill (1981, p. 35, rerecorded). Original discovery by the Bureau of Land Management Vernal District (Tucker 1974).

Site Dimensions/Area (approximate): $280 \mathrm{ft}$ east-west $\times 160 \mathrm{ft}$ north-south.

Site Description: The site is a lithic scatter near the $5,532 \mathrm{ft}$ benchmark. It consists of a small lithic concentration in a cleared sandy area; isolated artifacts were observed on an exposed bedrock outcrop overlooking the Green River. A rock alignment was reported to be at this site; however, this was not located.

Geomorphic Setting (e.g., bedrock knob, terrace alluvium): Sandy terrace; bedrock on the river's edge.

Sedimentary Context (e.g., sand, clay): Sand.

Vegetation (type and density): Grassy, with pinyon pine, juniper, sagebrush, and rabbitbrush. Ground visibility is poor in the thick grassy area.

Slope: $0^{\circ}$ at bedrock surface; approximately $10^{\circ}$ on slope where lithic concentration is located.

Distance to River/Stream Channel: Distance north from the benchmark is $50 \mathrm{ft}$; distance east from the benchmark is $160 \mathrm{ft}$; distance east from the benchmark to the creek is $80 \mathrm{ft}$.

Elevation above River/Stream Level: $14 \mathrm{ft}$ from river level to top of bedrock outcrop.

Impacts: Dirt road network appears to run through the site; also possible vandalism due to nearby campsites.

Photographs (note compass orientation):

Roll \#1 (John's Camera), B/W Plus-X Pan 125

Frame \#7: View looking east and slightly south from vicinity of 42DA332 downstream toward the site.

Frame \#8: View looking west and slightly north at the exposed edge of 6-ft terrace upstream from the site toward 42DA332.

Frame \#9: View looking southwest at the lithic scatter on bedrock.

Roll \#1 (Konnie's Camera), Color Prints

Frame \#2: View looking north and slightly east toward the bedrock outcrop and lithic scatter at the site. 


\section{ARCHAEOLOGICAL SITE IMPACT ANALYSIS DATA FORM Argonne National Laboratory}

Name: Konnie Moeller/Glade Hadden

Date: $06 / 17 / 92$

Time: $17: 00$

Site No: 42DA196 County/State: Daggett/Utah

USGS Map Reference: Warren Draw 7.5 minute Elevation (ft MSL): $5,400 \mathrm{ft}$

Site Reference (report, file): MAPCO, Woodward-Clyde (1980).

Site Dimensions/Area (approximate): Unknown.

Site Description: This site is a sparse lithic scatter comprised of a few blocky fragments and a large core imbedded in the sand.

Geomorphic Setting (e.g., bedrock knob, terrace alluvium): Bedrock outcrop.

Sedimentary Context (e.g., sand, clay): Sand and gravel.

Vegetation (type and density):

Slope: $0^{\circ}$.

Distance to River/Stream Channel:

Elevation above River/Stream Level:

Impacts: The site does not seem to be present anymore.

Photographs (note compass orientation):

Roll \#1 (Lynn's Camera) B/W Plus-X Pan 125

Frame \#22: View looking southwest toward Sears Creek at the river trolley near 42DA196. 


\section{ARCHAEOLOGICAL SITE IMPACT ANALYSIS DATA FORM Argonne National Laboratory}

Name: Bruce Verhaaren

Date: $06 / 17 / 92$

Time: 15:05

Site No: $42 \mathrm{DA} 203$

County/State: Daggett/Utah

USGS Map Reference: Clay Basin 7.5 minute Elevation (ft MSL): $5,430 \mathrm{ft}$

Site Reference (report, file): Madsen and Sargent (1979), Utah State Division of Wildlife Resources.

Site Dimensions/Area (approximate): $160 \mathrm{ft} \times 230 \mathrm{ft}$.

Site Description: The site is reported to be a large lithic scatter destroyed by construction of a stock pond and irrigation ditch. There is also a historic component of the site south of Tolivers Creek consisting of a dugout structure with possible log flooring, $16 \mathrm{ft} \times 20 \mathrm{ft}$ in size. Also associated with this structure is a stove, crockery, and glass fragments.

Geomorphic Setting (e.g., bedrock knob, terrace alluvium): Colluvial terrace; Browns Park.

Sedimentary Context (e.g., sand, clay): Sand, gravel to cobbles.

Vegetation (type and density): Sparse vegetation consisting of greasewood and juniper.

Slope: 1 to $2^{\circ}$.

Distance to River/Stream Channel: Located on the bank, less than $13 \mathrm{ft}$ from current river channel.

Elevation above River/Stream Level: $20 \mathrm{ft}$.

Impacts: Prehistoric site destroyed; no further impacts. Historic site impacted by cattle grazing.

Photographs (note compass orientation):

Roll \#1 (Lynn's Camera) B/W Plus-X Pan 125

Frame \#15: View looking northwest at the stock pond.

Frame \#16: View looking northwest at Tolivers Creek.

Frame \#17: View looking east at the historic component. 


\section{ARCHAEOLOGICAL SITE IMPACT ANALYSIS DATA FORM Argonne National Laboratory}

Name: Byron Loosle

Date: $06 / 16 / 92$

Time: $12: 30$

Site No: 42DA222

County/State: Daggett/Utah

USGS Map Reference: Goslin Mountain 7.5 minute Elevation ( $\mathrm{ft}$ MSL): 5,520 to $5,600 \mathrm{ft}$

Site Reference (report, file): Norman and Merrill (1981, p. 21), BLM 42DA199.

Site Dimensions/Area (approximate): Unknown.

Site Description: The site is a lithic scatter, with possible corrugated pottery. Appears to be potentially eligible for the National Register.

Geomorphic Setting (e.g., bedrock knob, terrace alluvium): High gravel terrace. Bedrock outcrops quite a distance behind it.

Sedimentary Context (e.g., sand, clay): Gravel.

Vegetation (type and density): Mostly pinyon pine and juniper, with little ground cover; some grass and sagebrush.

Slope:

Distance to River/Stream Channel: River channel is close; however, the site is on a very steep grade above the river.

Elevation above River/Stream Level: About 60 to $80 \mathrm{ft}$.

Impacts: None.

Photographs (note compass orientation):

None taken. 


\section{ARCHAEOLOGICAL SITE IMPACT ANALYSIS DATA FORM Argonne National Laboratory}

Name: Lynn Malinowski/Byron Loosle Date: 06/16/92 Time: 15:45

Site No: 42DA223/AS302 County/State: Daggett/Utah

USGS Map Reference: Goslin Mountain 7.5 minute Elevation (ft MSL): 5,620 to 5,640 $\mathrm{ft}$

Site Reference (report, file): Norman and Merrill (1981, p. 21), 42DA200.

Site Dimensions/Area (approximate): Unknown; eroding downslope.

Site Description: The site is a lithic scatter just southwest of a large, steep, sloping drainage. Waste flakes, several cores, and a few possible hammerstones were found at the site. The site is represented by a scatter that continues on the other side of the drainage. There does not appear to be two totally separate sites here. Lithics were also found in the drainage and are most probably washing out down the slope. Most of the material appeared to be a fine-grained chert of various colors, ranging from a dark gray to a whitish brown-gray.

Geomorphic Setting (e.g., bedrock knob, terrace alluvium): The site is located on a bench of the high colluvial terrace, sloping down toward the Green River.

Sedimentary Context (e.g., sand, clay): Sandy silt with small- to medium-sized gravel and large cobbles. Site is adjacent to a drainage containing large cobbles and boulders.

Vegetation (type and density): The site area consists mainly of pinyon pine, Utah juniper, prickly pear cactus, and small patches of grass. Ground visibility was nearly $100 \%$.

Slope: 10 to $20^{\circ}$ at main lithic concentration on the bench, $45^{\circ}$ downslope toward the river channel.

Distance to River/Stream Channel: Approximately 110 to $130 \mathrm{ft}$ to the river.

Elevation above River/Stream Level: Approximately 80 to $100 \mathrm{ft}$ above the river channel.

Impacts: Natural erosion is present down the steep slope. Vandalism/looting is not a concern; the site is situated very high above the river.

\section{Photographs (note compass orientation):}

Roll \#1 (Lynn's Camera) B/W Plus-X Pan 125

Frame \#9: View looking south across site.

Frame \#10: Flakes and lithic debris on site.

Frame \#11: View looking southeast from site toward the steep drainage.

Frame \#12: View looking northwest across the site.

Frame \#13: View looking south from the site toward the Green River.

Frame \#14: View looking north from the site. 


\section{ARCHAEOLOGICAL SITE IMPACT ANALYSIS DATA FORM Argonne National Laboratory}

Name: Lynn Malinowski/Byron Loosle

Date: 06/16/92

Time: 14:45

Site No: 42DA224/AS301

County/State: Daggett/Utah

USGS Map Reference: Goslin Mountain 7.5 minute Elevation (ft MSL): $5,620 \mathrm{ft}$

Site Reference (report, file): Norman and Merrill (1981, p. 21), 42DA201.

Site Dimensions/Area (approximate): Unknown; eroding downslope.

Site Description: Site is located on a high terrace above the Green River. The site is actually on the slope of the terrace and is washing down the slope. The site consists mainly of waste flakes, some possible core fragments, and other lithic debris or shatter. No apparent lithic concentrations are present on the site; it is widely scattered all over the slope and may be washing down from the plateau of terrace above.

Geomorphic Setting (e.g., bedrock knob, terrace alluvium): Slope of a colluvial terrace.

Sedimentary Context (e.g., sand, clay): Reddish silty sand, with a large amount of gravel and cobbles.

Vegetation (type and density): Pinyon pine, juniper, prickly pear cactus, and small, sparse patches of grasses. Ground visibility was approximately $80 \%$.

Slope: 20 to $45^{\circ}$.

Distance to River/Stream Channel: Approximately $160 \mathrm{ft}$.

Elevation above River/Stream Level: Approximately $70 \mathrm{ft}$ from elevation of the river.

Impacts: Natural erosion from steep slope. No vandalism likely; the site is located too high above the river and the footpath.

Photographs (note compass orientation):

Roll \#1 (Lynn's Camera) B/W Plus-X Pan 125

Frame \#4: View looking northwest at the site.

Frame \#5: View looking west at the site.

Frame \#6: View looking southeast from the site toward the river, downslope.

Frame \#7: View looking northeast from the site.

Frame \#8: View looking east-northeast from the site toward Little Hole Campground. 


\section{ARCHAEOLOGICAL SITE IMPACT ANALYSIS DATA FORM Argonne National Laboratory}

Name: Konnie Moeller/Byron Loosle

Date: $06 / 16 / 92$

Time: 11:30

Site No: 42DA227

County/State: Daggett/Utah

USGS Map Reference: Goslin Mountain 7.5 minute $\quad$ Elevation (ft MSL): $5,540 \mathrm{ft}$

Site Reference (report, file): Norman and Merrill (1981, p. 23), BLM 42DA205.

Site Dimensions/Area (approximate): Unknown.

Site Description: This site is some type of mine, with several retaining walls still intact.

Geomorphic Setting (e.g., bedrock knob, terrace alluvium): High gravel terrace.

Sedimentary Context (e.g., sand, clay): Gravel and cobbles.

Vegetation (type and density): Mostly a low, grassy cover.

Slope: Various slope angles associated with the structural remains.

Distance to River/Stream Channel: Approximately $150 \mathrm{ft}$.

Elevation above River/Stream Level: $20 \mathrm{ft}$ terrace level.

Impacts: Potential vandalism; the site is very accessible to campers and boaters.

Photographs (note compass orientation):

Roll \# 1 (Lynn's Camera) B/W Plus-X Pan 125

Frame \#1: View looking southwest toward the mine (center).

Frame \#2: Close-up view looking southwest at the mine. 


\section{ARCHAEOLOGICAL SITE IMPACT ANALYSIS DATA FORM Argonne National Laboratory}

Name: Konnie Moeller/Byron Loosle

Date: $06 / 16 / 92$

Time: $12: 00$

Site No: 42DA275

County/State: Daggett/Utah

USGS Map Reference: Goslin Mountain 7.5 minute Elevation (ft MSL): 5,520 to 5,560 ft

Site Reference (report, file): Norman and Merrill (1981, p. 22) (BLM 42DA202).

Site Dimensions/Area (approximate): Not recorded.

Site Description: This site is a small lithic scatter on the bedrock surface above the river. Because it is several feet above the river and appears to be out of the scope for impacts by the river, no measurements were taken other than elevation.

Geomorphic Setting (e.g., bedrock knob, terrace alluvium): Bedrock outcrop.

Sedimentary Context (e.g., sand, clay): Red soil and bedrock surface.

Vegetation (type and density): Very little cover; comprised of prickly pear cactus, sagebrush, pinyon pine, ponderosa pine, juniper, and others. Good ground visibility.

Slope: 0 to $10^{\circ}$.

Distance to River/Stream Channel: Approximately $40 \mathrm{ft}$.

Elevation above River/Stream Level: Approximately $24 \mathrm{ft}$.

Impacts: None.

Photographs (note compass orientation):

Roll \#1 (Lynn's Camera) B/W Plus-X Pan 125

Frame \#3: View looking north-northeast at site. 


\section{ARCHAEOLOGICAL SITE IMPACT ANALYSIS DATA FORM Argonne National Laboratory}

Name: John Hoffecker/Lynn Malinowski Date: 06/16/92 Time: 11:00

Site No: 42DA332 County/State: Daggett/Utah

USGS Map Reference: Goslin Mountain 7.5 minute Elevation (ft MSL): 5,540 to $5,550 \mathrm{ft}$

Site Reference (report, file): Norman and Merrill (1981, p.23), BLM 42DA206.

Site Dimensions/Area (approximate): About $100 \mathrm{ft} \times 150 \mathrm{ft}$.

Site Description: Prehistoric lithic scatter/historic corral. The corral is composed of several wooden posts and barbed wire. Lithic scatter includes flakes, one side-notched point, and possible core fragments. The raw material is quite varied; low-quality and high-quality chert and some sandstone pieces are present.

Geomorphic Setting (e.g., bedrock knob, terrace alluvium): Alluvial terrace composed of sand and cobbles.

Sedimentary Context (e.g., sand, clay): Sand.

Vegetation (type and density): Low shrubs and grasses. Visibility varies from 20 to $60 \%$.

Slope: $20^{\circ}$ on the top of the terrace to $30-40^{\circ}$ at edge of the terrace. Some material is washing out down the slope.

Distance to River/Stream Channel: Approximately $400 \mathrm{ft}$.

Elevation above River/Stream Level: Approximately $20 \mathrm{ft}$ above the level of the river.

Impacts: Some erosion along the slope of the terrace; possibly some vandalism although this is not completely clear.

\section{Photographs (note compass orientation):}

Roll \#I (John's Camera) B/W Plus-X Pan 125

Frame \#1: No photograph.

Frame \#2: View looking southwest at remains of historic corral.

Frame \#3: View looking northeast at lithic scatter.

Frame \#4: Close-up view of a waste flake at approximate center of the site.

Frame \#5: Close-up view of side-notched projectile point found at the site.

Frame \#6: View looking southwest from the river's edge toward the site.

Frame \#7: View looking east (slightly south) downstream toward site 42DA40.

Frame \#8: View looking northwest toward the lowest (8- $\mathrm{ft}$ ) terrace level.

Frame \#9: View looking southwest at lithic scatter $42 \mathrm{DA} 40$ on bedrock. 


\section{ARCHAEOLOGICAL SITE IMPACT ANALYSIS DATA FORM Argonne National Laboratory}

Name: John Hoffecker/Lynn Malinowski Date: 06/16/92 Time: About 12:30

Site No: 42DA335 County/State: Daggett/Utah

USGS Map Reference: Goslin Mountain 7.5 minute Elevation (ft MSL):

Site Reference (report, file): Norman and Merrill (1981, p. 25), BLM 42DA209.

Site Dimensions/Area (approximate): Unknown; scattered for $>100 \mathrm{ft}$ along terrace margin.

Site Description: Lithic scatter located along "second" terrace edge (about $16 \mathrm{ft}$ ). Lithic debris, including numerous large flakes of poor-quality chert and other poor- to medium-quality material.

Geomorphic Setting (e.g., bedrock knob, terrace alluvium): Alluvial terrace of sand/gravel.

Sedimentary Context (e.g., sand, clay): Surficial, resting on sandstone.

Vegetation (type and density): Sparse vegetation consisting of pinyon pine/juniper, prickly pear cactus, and some grasses. Ground visibility is 75 to $100 \%$.

Slope: $5^{\circ}$. Steeper slope at terrace margin.

Distance to River/Stream Channel: About 50 to $70 \mathrm{ft}$.

Elevation above River/Stream Level: About $20 \mathrm{ft}$.

Impacts: Erosion at edge of terrace; possible vandalism due to nearby campsites.

Photographs (note compass orientation):

Roll \#1 (John's Camera) B/W Plus/X Pan 125

Frame \#10: View looking north at a small lithic flake concentration at the edge of the terrace.

Frame \#11: View looking east along the edge of the terrace at lithic scatter.

Frame \#12: View looking west along the edge of the terrace.

Frame \#13: View from the north side of the river looking across at the site.

Frame \#14: View looking southwest and upstream from the north side of the river at more lithic debris scattered on the 20 - $\mathrm{ft}$ terrace. 


\section{ARCHAEOLOGICAL SITE IMPACT ANALYSIS DATA FORM Argonne National Laboratory}

Name: Bruce Verhaaren

Site No: 42DA339/241
Date: $06 / 17 / 92$ Time: 17:10

USGS Map Reference: Warren Draw 7.5 minute Elevation (ft MSL): $5,400 \mathrm{ft}$

Site Reference (report, file): Norman and Merrill (1981, p. 28), BLM 42DA214/215.

Site Dimensions/Area (approximate): $330 \mathrm{ft} \times 130 \mathrm{ft}$ (L-shaped).

Site Description: The two sites recorded as 42DA339 and 42DA241 actually appear to be one site. The site is comprised of a lithic scatter, including grinding stones, a metate, and several burned areas or deposits that may be hearths. Appears to be a seasonal campsite or processing station. The site is scattered along the Green River and two nearby intermittent streams.

Geomorphic Setting (e.g., bedrock knob, terrace alluvium): Colluvial terrace.

Sedimentary Context (e.g., sand, clay): Sandy loam, with quartzite gravel to cobbles.

Vegetation (type and density): Sparse vegetation consisting of greasewood, saltbrush, and low sage.

Slope: 1 to $2^{\circ}$.

Distance to River/Stream Channel: 160 to $330 \mathrm{ft}$.

Elevation above River/Stream Level: About $16 \mathrm{ft}$.

Impacts: Cattle grazing; possibly impacted by bank erosion due to increased flow if water level rises above cobbles on shore.

Photographs (note compass orientation):

Roll \#1 (Lynn's Camera) B/W Plus-X Pan 125

Frame \#20: View looking west at the hearth.

Frame \#21: Close-up view looking west at the metate fragment. 


\section{ARCHAEOLOGICAL SITE IMPACT ANALYSIS DATA FORM Argonne National Laboratory}

Name: Hoffecker/Malinowski/Moeller/Verhaaren

Date: 06/19/92

Time: $10: 40$

Site No: $42 \mathrm{DA} 342$

County/State: Daggett/Utah

USGS Map Reference: Clay Basin 7.5 minute Elevation (ft MSL): 5,430 to $5,440 \mathrm{ft}$

Site Reference (report, file): Norman and Merrill (1981, p. 26-27), BLM 42DA212.

Site Dimensions/Area (approximate): About $100 \mathrm{ft} \times 20 \mathrm{ft}$ along river.

Site Description: Possible trenches, intersecting with the river, and numerous wooden beams and railroad ties were found near the site of the bridge crossing. The dugouts were not found.

Geomorphic Setting (e.g., bedrock knob, terrace alluvium): High floodplain.

Sedimentary Context (e.g., sand, clay): Sand and gravel.

Vegetation (type and density): Tamarisk, willow, and aspen dominate the vegetation along the river.

Slope: $10^{\circ}$.

Distance to River/Stream Channel: Approximately $70 \mathrm{ft}$.

Elevation above River/Stream Level: $5 \mathrm{ft}$.

Impacts: Impacts unclear; possibly some construction impacts on 20 -ft terrace level above the site.

Photographs (note compass orientation):

Roll \#2 (Lynn's Camera) B/W Plus-X Pan 125

Frame \#9: View looking south toward the wooden beams at the site. 


\section{ARCHAEOLOGICAL SITE IMPACT ANALYSIS DATA FORM \\ Argonne National Laboratory}

Name: John Hoffecker Date: $05 / 14 / 92^{*} \quad$ Time: $16: 30$

Site No: 42DA485 County/State: Daggett/Utah

USGS Map Reference: Clay Basin 7.5 minute Elevation (ft MSL): About 5,435 ft

Site Reference (report, file): IMACS from Metcalf Archaeological Consultants (1988) for Questar North-South Pipeline Project.

Site Dimensions/Area (approximate): Unknown.

Site Description: This site appears to be a lithic scatter on a sandy terrace edge. A thin sand deposit overlies gravel alluvium in a sandy matrix. One black chert waste flake and a possible reddish-brown chert blade fragment were found on the surface.

Geomorphic Setting (e.g., bedrock knob, terrace alluvium): Appears to rest on a 16-ft terrace.

Sedimentary Context (e.g., sand, clay): Sand, overlying sandy gravel alluvium.

Vegetation (type and density): Low grasses and shrubs, some bare areas as well.

Slope: 5 to $30^{\circ}$.

Distance to River/Stream Channel: $80 \mathrm{ft}$.

Elevation above River/Stream Level: $15 \mathrm{ft}$.

Impacts: Construction disturbance; possible looting, erosion, and trampling. Construction includes a road leading down to the floodplain.

Photographs (note compass orientation):

Ground-truthing Roll (John's Camera) Color Prints

Frame \#13: Close-up view looking south at lithic scatter and Jack Pfingston.

Frame \#14: View looking northeast along 16-ft terrace edge toward lithic scatter and Jack.

*This site was relocated prior to the field study during a ground-truthing expedition for an aerial videography flyover of the river. 


\section{ARCHAEOLOGICAL SITE IMPACT ANALYSIS DATA FORM \\ Argonne National Laboratory}

Name: John Hoffecker/Konnie Moeller Date: 06/16/92 Time: 16:30

Site No: 42DA561 County/State: Daggett/Utah

USGS Map Reference: Goslin Mountain 7.5 minute Elevation (ft MSL): $5,520 \mathrm{ft}$

Site Reference (report, file): New site.

Site Dimensions/Area (approximate): 75 to $100 \mathrm{ft}$ along terrace margin.

Site Description: The site is a lithic scatter on the 16- to 20 - $\mathrm{ft}$ terrace level along the margin of the terrace. The site contains sparsely distributed flakes of varying size and raw material.

Geomorphic Setting (e.g., bedrock knob, terrace alluvium): Alluvial terrace/fan.

Sedimentary Context (e.g., sand, clay): Sand and cobbles.

Vegetation (type and density): Visibility is poor, except in occasional blowout areas and in areas where a small stream has incised the terrace/fan.

Slope: $10^{\circ}$.

Distance to River/Stream Channel: 30 to $35 \mathrm{ft}$.

Elevation above River/Stream Level: $18 \mathrm{ft}$.

Impacts: Some erosion is present along the terrace margin.

Photographs (note compass orientation):

Roll \#1 (John's Camera) B/W Plus-X Pan 125

Frame \#15: View looking east at lithic scatter.

Frame \#16: View looking south at the stream cut through terrace.

Frame \#17: View looking east at eroding terrace edge where several flakes are located. 


\section{ARCHAEOLOGICAL SITE IMPACT ANALYSIS DATA FORM Argonne National Laboratory}

Name: John Hoffecker/Lynn Malinowski

Date: $06 / 17 / 92$

Time: $11: 40$

Site No: $42 \mathrm{DA} 562$

County/State: Daggett/Utah

USGS Map Reference: Clay Basin 7.5 minute Elevation (ft MSL): $5,480 \mathrm{ft}$

Site Reference (report, file): New site.

Site Dimensions/Area (approximate): Unknown.

Site Description: The site is a small lithic concentration that was found to be eroding out of the sloping alluvial fan edge. The concentration was comprised of one ovate biface of brown chert, one retouched end scraper of gray chert, and three flakes.

Geomorphic Setting (e.g., bedrock knob, terrace alluvium): Side-valley fan. Artifacts are eroding out of fan edge.

Sedimentary Context (e.g., sand, clay): Sand and gravel.

Vegetation (type and density): Pinyon pine, juniper, sagebrush, prickly pear cactus, and other low shrubs and grasses. Ground visibility was $100 \%$ at the site.

Slope: $15^{\circ}$.

Distance to River/Stream Channel: $150 \mathrm{ft}$ (river was low).

Elevation above River/Stream Level: $15 \mathrm{ft}$ (river was low and the side-valley stream was dry).

Impacts: Impact agents appear to be erosion and possible vandalism. People have camped within $20 \mathrm{ft}$ of the site.

Photographs (note compass orientation):

Roll \#1 (John's Camera) B/W Plus-X Pan 125

Frame \#19: View looking east, downstream of terraces on the south side of the river, and location of the site on the fan (center).

Frame \#20: Close-up view of lithic scatter.

Frame \#21: View looking southeast from the river floodplain at the site (two prints were developed for this frame).

Frame \#22: View looking northeast from the river floodplain at the site.

Frame \#23: Close-up view of the lithic scatter.

Frame \#24: View looking east at bedrock ledge, downstream of 42DA562, at location of isolated flake.

Frame \#24A: View looking east at bedrock ledge, downstream of 42DA562, and east of frame \#24. 


\section{ARCHAEOLOGICAL SITE IMPACT ANALYSIS DATA FORM Argonne National Laboratory}

Name: John Hoffecker/Lynn Malinowski

Date: $06 / 17 / 92$

Time: 16:00

Site No: $42 D A 563$

County/State: Daggett/Utah

USGS Map Reference: Clay Basin 7.5 minute Elevation (ft MSL): $5,480 \mathrm{ft}$

Site Reference (report, file): New site.

Site Dimensions/Area (approximate): Unknown.

Site Description: The site is a lithic scatter located along the edge of an alluvial fan deposited below a side-valley stream. Flakes, a retouched blade, and a biface were found scattered near the mouth of the dry creek at the edge of the fan. It appears that the lithic concentration is located on the edge of two superimposed fans. A 20th century historic trash scatter may also be associated with this site on the basis of the presence of several fragments from a Coca-Cola bottle.

Geomorphic Setting (e.g., bedrock knob, terrace alluvium): Alluvial side-valley fan.

Sedimentary Context (e.g., sand, clay): Sand and gravel.

Vegetation (type and density): Pinyon pine, juniper, sagebrush, prickly pear cactus, and other numerous low shrubs and grasses occur near the site.

Slope: 2 to $5^{\circ}$ to about $25^{\circ}$.

Distance to River/Stream Channel: $80 \mathrm{ft}$ to the edge of fan and low lithic scatter, and $160 \mathrm{ft}$ to the material found at the higher level.

Elevation above River/Stream Level: Lowest scatter is at $10 \mathrm{ft}$ above the river level; highest scatter is at $20 \mathrm{ft}$ above the river level.

Impacts: A road running near the site has impacted it. The site is also subject to aeolian and slope wash erosion.

\section{Photographs (note compass orientation):}

Roll \#2 (John's Camera) B/W Plus-X Pan 125

Frame \#1: View looking southeast toward the site at the edge of the fan. 


\section{ARCHAEOLOGICAL SITE IMPACT ANALYSIS DATA FORM Argonne National Laboratory}

Name: Bruce Verhaaren

Date: 06/17/92

Time: 15:45

Site No: 42DA564

County/State: Daggett/Utah

USGS Map Reference: Clay Basin 7.5 minute Elevation (ft MSL): $5,420 \mathrm{ft}$

Site Reference (report, file): New site.

Site Dimensions/Area (approximate): $130 \mathrm{ft} \times 30 \mathrm{ft}$.

Site Description: The site consists of three hearths, approximately $3 \mathrm{ft}$ in diameter, discovered on the bank of the Green River. A few flakes, groundstone, and fire-cracked rock were also present.

Geomorphic Setting (e.g., bedrock knob, terrace alluvium): Colluvial terrace, glacial valley train, on the bank of the Green River.

Sedimentary Context (e.g., sand, clay): Sandy loam.

Vegetation (type and density): Willow, greasewood, and grasses.

Slope: $1^{\circ}$.

Distance to River/Stream Channel: On riverbank near possible spring.

Elevation above River/Stream Level: About $10 \mathrm{ft}$.

Impacts: Erosion, fence line, and wetland habitat construction.

Photographs (note compass orientation):

Roll \#1 (Lynn's Camera) B/W Plus-X Pan 125

Frame \#18: View looking west at the east hearth.

Frame \#19: View looking north at the middle hearth. 


\section{ARCHAEOLOGICAL SITE IMPACT ANALYSIS DATA FORM Argonne National Laboratory}

Name: Konnie Moeller/Bruce Verhaaren Date: 06/18/92 Time: 19:00

Site No: 5MF605 County/State: Moffat/Colorado

USGS Map Reference: Lodore School 7.5 minute Elevation (ft MSL): $5,354 \mathrm{ft}$

Site Reference (report, file): Eddy et al. (1982).

Site Dimensions/Area (approximate): $160 \mathrm{ft} \times$ ?

Site Description: This site is the supposed location of Fort Davy Crockett/Fort Misery. There is only one fragment of wood on the surface; no artifacts were found. Just south of some of the pilings in the river, black plastic from the back-filled excavation protrudes out of the eroded cutbank of the river. An excavation stake located at the northwest edge of the excavation area will probably erode from the bank soon; it is about $1.5 \mathrm{ft}$ from the edge of the cutbank. Approximately $160 \mathrm{ft}$ north are some late 19 th century glass and metal fragments on the surface.

Geomorphic Setting (e.g., bedrock knob, terrace alluvium): Sandy terrace.

Sedimentary Context (e.g., sand, clay): Sand.

Vegetation (type and density): Low scrubs and grass. Visibility away from the bank edge is zero.

Slope: $0^{\circ}$.

Distance to River/Stream Channel: On river bank.

Elevation above River/Stream Level: $6 \mathrm{ft}$.

Impacts: Evidence of excavation units eroding from the side of the cutbank; however, no cultural material was observed.

Photographs (note compass orientation):

Roll \#2 (Lynn's Camera) B/W Plus-X Pan 125

Frame \#5: View looking east at the remains of previous excavations.

Frame \#6: View looking south at the excavations eroding from terrace edge.

Frame \#7: View looking south at the excavations eroding from terrace edge; $\mathrm{K}$ Moeller in center, right.

Frame \#8: Close-up view of the historic trash scatter. 


\section{ARCHAEOLOGICAL SITE IMPACT ANALYSIS DATA FORM \\ Argonne National Laboratory}

Name: John Hoffecker/Lynn Malinowski

Date: $06 / 18 / 92$

Time: 16:00

Site No: 5MF840 County/State: Moffat/Colorado

USGS Map Reference: Lodore School 7.5 minute Elevation (ft MSL): $5,400 \mathrm{ft}$

Site Reference (report, file): Meyer and Riches (1979).

Site Dimensions/Area (approximate): $50 \mathrm{ft} \times 50 \mathrm{ft}$ (new section) added to the original site area recorded by Meyer and Riches.

Site Description: Lithic scatter composed of flakes of varying raw material (good- and poor-quality chert), and one projectile point. Several large cobbles (manuports) are also present on the site. Also found small lithic scatter to the northeast previously recorded by Meyer and Riches in 1979.

Geomorphic Setting (e.g., bedrock knob, terrace alluvium): Sandy alluvial terrace.

Sedimentary Context (e.g., sand, clay): Sand.

Vegetation (type and density): Sage, grasses, and some pinyon pine.

Slope: 20 to $30^{\circ}$.

Distance to River/Stream Channel: Approximately 100 to $130 \mathrm{ft}$.

Elevation above River/Stream Level: $15 \mathrm{ft}$.

Impacts: Stream and aeolian erosion possible at both portions of the site.

Photographs (note compass orientation):

Roll \#2 (John's Camera) B/W Plus-X Pan 125

Frame \#7: View looking northwest across Flynn Cabin site (5MF1231) toward the new lithic scatter belonging to Site 5MF840.

Frame \#8: Close-up view looking northwest at Flynn Cabin.

Frame \#9: Close-up view of projectile point found at the site.

Frame \#10: View looking west from the lithic scatter.

Frame \#11: Close-up view of lithic scatter and manuports.

Frame \#12: Close-up view of bone found in buried organic layer.

Frame \#13: View looking at cutbank of sandy terrace with bone in the buried organic layer. 


\section{ARCHAEOLOGICAL SITE IMPACT ANALYSIS DATA FORM Argonne National Laboratory}

Name: John Hoffecker/Lynn Malinowski Date: 06/18/92 Time: 18:30

Site No: 5MF841 County/State: Moffat/Colorado

USGS Map Reference: Lodore School 7.5 minute Elevation (ft MSL): About 5,340 ft

Site Reference (report, file): Meyer and Riches (1979).

Site Dimensions/Area (approximate): Unknown.

Site Description: Isolated lithic artifacts, notably low-grade reddish chert core/chopper. Also present are unnatural depressions.

Geomorphic Setting (e.g., bedrock knob, terrace alluvium): Sandy alluvium/bedrock outcrops.

Sedimentary Context (e.g., sand, clay): Sand.

Vegetation (type and density): Mainly low shrubs and grasses. Ground visibility is 50\%.

Slope: 0 to $5^{\circ}$.

Distance to River/Stream Channel: Approximately $300 \mathrm{ft}$.

Elevation above River/Stream Level: About $8 \mathrm{ft}$.

Impacts: Undetermined. Possible vandalism, although the likelihood of anyone accessing the site is small.

Photographs (note compass orientation):

Roll \#2 (John's Camera) B/W Plus-X Pan 125

Frame \# 24: View looking east across the site toward riverbank (marked by a large cottonwood tree). 


\section{ARCHAEOLOGICAL SITE IMPACT ANALYSIS DATA FORM Argonne National Laboratory}

Name: John Hoffecker/Lynn Malinowski

Date: $06 / 18 / 92$

Time: $12: 00$

Site No: 5MF1228

County/State: Moffat/Colorado

USGS Map Reference: Swallow Canyon 7.5 minute Elevation (ft MSL): $5,400 \mathrm{ft}$

Site Reference (report, file): Norman and Merrill (1981, p. 29).

Site Dimensions/Area (approximate): Unknown.

Site Description: The site is a lithic scatter composed of approximately 5 to 10 flakes of brown, whitish gray, medium-grade chert, medium-grade light brown chert, and quartzite.

Geomorphic Setting (e.g., bedrock knob, terrace alluvium): Bedrock mantled with slope deposits of sand, gravel, and rocks.

Sedimentary Context (e.g., sand, clay): Sand and gravel.

Vegetation (type and density): Sage, prickly pear cactus, and low grasses. Ground visibility is $80 \%$.

Slope: $20^{\circ}$.

Distance to River/Stream Channel: About $110 \mathrm{ft}$.

Elevation above River/Stream Level: About $16 \mathrm{ft}$.

Impacts: Possibly some natural erosion from the slope.

Photographs (note compass orientation):

Roll \#2 (John's Camera) B/W Plus-X Pan 125

Frame \#3: View of the mouth of Beaver Creek, seen from the south side of the river, en route to sites 5MF1228 and 5MF1229.

Frame \#4: View looking east and slightly south toward bedrock outcrop, lithic scatter 5MF1228, and historic trash scatter 5MF1229. 


\section{ARCHAEOLOGICAL SITE IMPACT ANALYSIS DATA FORM Argonne National Laboratory}

Name: Konnie Moeller/Bruce Verhaaren

Date: 06/18/92

Time: $18: 00$

Site No: $5 \mathrm{MF} 1234$

County/State: Moffat/Colorado

USGS Map Reference: Lodore School 7.5 minute Elevation (ft MSL): $5,440 \mathrm{ft}$

Site Reference (report, file): Norman and Merrill (1981, p. 32).

Site Dimensions/Area (approximate): $360 \mathrm{ft} \times 230 \mathrm{ft}$.

Site Description: The historic site consists of a collapsed wooden structure with pieces of timber, including dimensional lumber, scattered throughout the area. Quite a bit of material is scattered among the cottonwood trees, including metal scrap. Timber is present at the edge of the river cutbank, and a portion of the structure appears to be eroding out of the cutbank. A fallen tree has already broken away from the bank, and a metal washtub is in danger of falling from the cutbank into the river.

Geomorphic Setting (e.g., bedrock knob, terrace alluvium): Alluvial terrace.

Sedimentary Context (e.g., sand, clay): Sand.

Vegetation (type and density): A dry, grassy cover with low shrubs, such as greasewood and saltbrush, in a cottonwood grove. Beavers have been at the cottonwoods.

Slope: $0^{\circ}$.

Distance to River/Stream Channel: On the riverbank.

Elevation above River/Stream Level: $11 \mathrm{ft}$.

Impacts: Erosion of the riverbank has already undercut some of the site.

Photographs (note compass orientation):

Roll \#2 (Lynn's Camera) B/W Plus-X Pan 125

Frame \#0: View looking northeast at the plow.

Frame \#1: View looking south along terrace edge at the eroding timber.

Frame \#2: View looking south at eroding timber.

Frame \#3: View looking north at the historic artifact scatter.

Frame \#4: View looking east at the collapsed walls. 


\section{ARCHAEOLOGICAL SITE IMPACT ANALYSIS DATA FORM Argonne National Laboratory}

Name: Bruce Verhaaren/Konnie Moeller

Date: 06/18/92

Time: $12: 00$

Site No: 5MF1238

County/State: Moffat/Colorado

USGS Map Reference: Swallow Canyon 7.5 minute Elevation (ft MSL): $5,380 \mathrm{ft}$

Site Reference (report, file): Norman and Merrill (1981, p. 34).

Site Dimensions/Area (approximate): $50 \mathrm{ft} \times 70 \mathrm{ft}$.

Site Description: The site is a light lithic scatter, possibly associated with a fallen rockshelter. Flakes and a biface made of brown translucent (obsidian-like) chert was discovered on-site, washing down from rim rock.

Geomorphic Setting (e.g., bedrock knob, terrace alluvium): Bedrock and colluvial deposits.

Sedimentary Context (e.g., sand, clay): Sandy loam with large angular quartzite fragments.

Vegetation (type and density): Fairly dense vegetation consisting of greasewood and cactus.

Slope: 2 to $8^{\circ}$.

Distance to River/Stream Channel: Less than $330 \mathrm{ft}$.

Elevation above River/Stream Level: 10 to $20 \mathrm{ft}$.

Impacts: Site is impacted by a road cut through the site; the road is used by visitors to the refuge, who may also impact it. A pump and irrigation canal is present to the east of the site, and collapsed rim rock occurs on-site.

Photographs (note compass orientation):

Roll \#1: (Lynn's Camera) B/W Plus-X Pan 125

Frame \#23: View looking west across the site. 


\section{ARCHAEOLOGICAL SITE IMPACT ANALYSIS DATA FORM Argonne National Laboratory}

Name: Lynn Malinowski Date: $05 / 15 / 92^{*} \quad$ Time: $13: 30$

Site No: 5MF2655 County/State: Moffat/Colorado

USGS Map Reference: Canyon of Lodore South 7.5 minute ${ }^{* *}$ Elevation (ft MSL): 5,080 ft

Site Reference (report, file): Truesdale (1989) (ANL 3FG-16).

Site Dimensions/Area (approximate): $260 \mathrm{ft} \times 160 \mathrm{ft}$ (difficult to tell due to ground cover).

Site Description: This site is a prehistoric lithic scatter located on a 32-ft terrace. The site contains a small amount of chipped stone (flakes, shatter, core fragments). Raw material varies in terms of quality and color: There is a white, reddish purple, and grayish white fine-grained chert, as well as a brown, white, and red quartzite. Surface visibility is poor at this site, about $20 \%$. Consequently, it is difficult to tell whether the site extends over the entire "knoll," although it appears to.

Geomorphic Setting (e.g., bedrock knob, terrace alluvium): Northwest of the confluence of the Green and Yampa Rivers, the site is situated on an alluvial terrace adjacent to extremely high sandstone cliffs.

Sedimentary Context (e.g., sand, clay): Orange/yellow, fine-grained silty sand with a mixture of gravel and large cobbles. Some cobbles may be manuports, but this is unclear.

Vegetation (type and density): Fairly dense transitional vegetation on the terrace: pinyon pine, juniper, sage, scrub oak, and low shrubs and grasses with much prickly pear cactus. Adjacent riparian vegetation included cottonwoods, willows, tamarisk (non-native), and backwater grasses.

Slope: 0 to $20^{\circ}$ on terrace; approximately $40^{\circ}$ on the terrace slope.

Distance to River/Stream Channel: $230 \mathrm{ft}$ west.

Elevation above River/Stream Level: $44 \mathrm{ft}$.

Impacts: The site has been subject to vandalism because of the nearby campground and easy access to the site; the site is also subject to some natural erosion of the terrace.

\section{Photographs (note compass orientation):}

Roll \#1 (Lynn's Camera) Color 100 Film

Frame \#13: View looking east from the Echo Park Campground Road at the site.

Frame \#14: View looking north-northwest from site toward the confluence of the Green and Yampa Rivers.

Frame \#15: View looking south-southwest from site toward the only large tree on the site.

Frame \#16: View looking southwest from site toward the Echo Park Campground on the river.

Frame \#17: View looking southeast and down at the grassy cover and lithics at the site.

Frame \#18: Close-up view of the lithic debris found at the site.

Frame \#19: View looking southeast and down at the cobbles in the grassy cover at the site.

*This site was located prior to the field study during a ground-truthing expedition for an aerial videography flyover of the river.

***This site is included with the site forms because it was relocated; however, based on the defined field study area, the site is below the Yampa confluence and would not otherwise be included. 


\section{ARCHAEOLOGICAL SITE IMPACT ANALYSIS DATA FORM \\ Argonne National Laboratory}

Name: Bruce Verhaaren/Konnie Moeller Date: 06/18/92 Time: $13: 30$

Site No: 5MF3668 County/State: Moffat/Colorado

USGS Map Reference: Swallow Canyon 7.5 minute Elevation (ft MSL): $5,360 \mathrm{ft}$

Site Reference (report, file): New site.

Site Dimensions/Area (approximate): Unknown.

Site Description: Site consists of a light lithic scatter washing down a cut in the sandy terrace. A possible hearth is located with the lithics in the cut, but it is difficult to tell whether the hearth is associated with the lithics. Lithics were primarily of two different kinds of chert: a dark gray (almost black) with a tan colored cortex; and a brown, more translucent chert.

Geomorphic Setting (e.g., bedrock knob, terrace alluvium): Terrace alluvium.

Sedimentary Context (e.g., sand, clay): Sandy loam.

Vegetation (type and density): Rabbitbrush and other low shrubs.

Slope: 1 to $2^{\circ}$.

Distance to River/Stream Channel: $3 \mathrm{ft}$ on riverbank.

Elevation above River/Stream Level: $10 \mathrm{ft}$.

Impacts: Erosion from path (cut) leading down to river; also possible vandalism due to the location near the road and comfort station.

Photographs (note compass orientation):

Roll \#1 (Lynn's Camera) B/W Plus-X Pan 125

Frame \#24: View looking south-southwest at the charcoal lense.

Frame \#24A: View looking northeast at the site from the river.

Roll \#1 (Konnie's Camera) Color Prints

Frame \#6: Example of the sandy terrace on which 5MF3668 is located. 


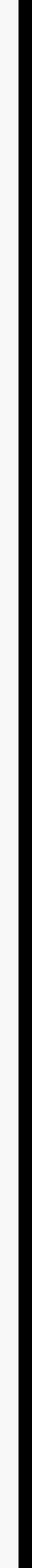

